
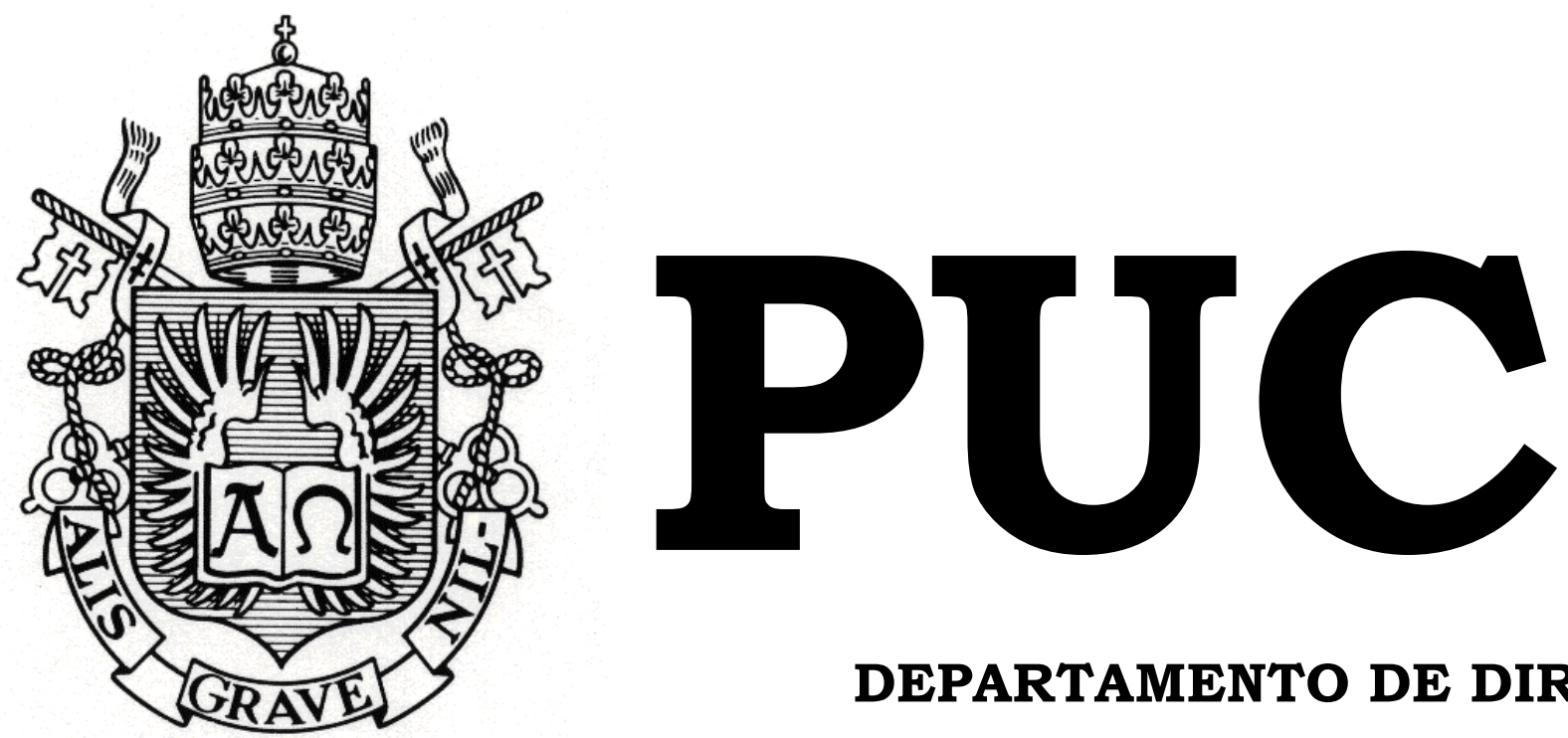

DEPARTAMENTO DE DIREITO

\title{
Ação Civil Pública e o Acesso ao Serviço Público de Saneamento Básico
}

$$
\text { por }
$$

Marcelo Hosken da Silva Matias

ORIENTADORA: Isabella Franco Guerra

2018.1

PONTIFÍCIA UNIVERSIDADE CATÓLICA DO RIO DE JANEIRO

RUA MARQUÊS DE SÃO VICENTE, 225 - CEP 22453-900

RIO DE JANEIRO - BRASIL 


\title{
Ação Civil Pública e o Acesso ao Serviço Público de Saneamento Básico
}

\author{
por \\ Marcelo Hosken da Silva Matias
} Monografia apresentada ao
Departamento de Direito da
Pontifícia Universidade Católica do
Rio de Janeiro (PUC-Rio) como
requisito parcial para obtenção do
Título de Bacharel em Direito.

Orientadora: Isabella Franco Guerra 


\section{RESUMO}

Nesta monografia, examina-se a ação civil pública tendo como objeto a concretização de políticas públicas, especificamente relacionadas ao saneamento básico, a fim de alcançar-se a efetivação de um direito social prestacional. Verifica-se a possibilidade jurídica do pedido neste processo coletivo, a realização de prestações positivas, pelo Estado, na área do saneamento básico, e alguns efeitos da decisão judicial (sobretudo os impactos orçamentários), discutindo-se, assim, se esse é o instrumento jurídico correto para judicializar essa questão relativa ao direito social ao saneamento básico.

\section{Palavras-Chave}

direito ambiental, direito constitucional, direito administrativo, ação civil pública, processo coletivo, direitos difusos, direitos sociais fundamentais, saneamento básico, leis, decisões judiciais, políticas públicas, reserva do possível, alcance das decisões judiciais. 


\section{SUMÁRIO}

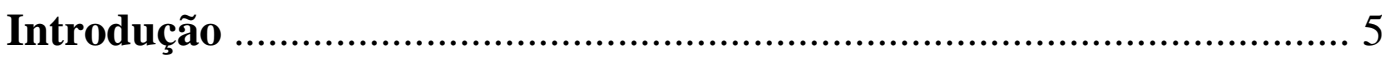

\section{Capítulo 1. Saneamento Básico: Aspectos Gerais}

1.1. Conceito de Saneamento Básico ........................................................ 7

1.2. Serviço Público e Saneamento Básico ..................................................... 9

1.3. Saneamento Básico Enquanto Direito Social ...................................... 12

1.4. Regime Jurídico do Saneamento Básico ............................................... 14

1.5. Competências dos Entes Federativos em Matéria de Saneamento Básico

1.6. Meio Ambiente Equilibrado e Direito Difuso ao Saneamento Básico 25

Capítulo 2. Ação Civil Pública e a Efetividade de Políticas Públicas para Acesso ao Sistema de Saneamento Básico

2.1. Processo Coletivo, Jurisdição e a Ação Civil Pública na Tutela de

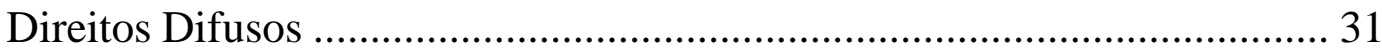

2.1.1. Princípios do Processo Coletivo …………………………………....... 34

2.2. Ação Civil pública e Direitos Difusos................................................... 37

2.3. Ação Civil Pública: Disposições Gerais e Aspectos Processuais ......... 40

2.3.1. Competência na Ação Civil Pública .................................................. 45

2.4. Sentença e Efeitos da Decisão na Ação Civil Pública que Tutela Direitos

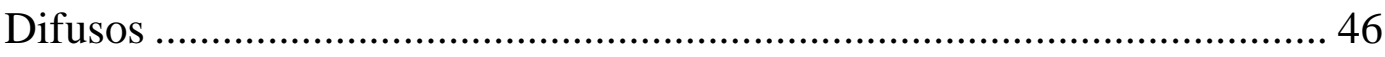

2.4.1. Fundo de Defesa de Direitos Difusos ................................................. 48

2.5. Ação Civil Pública na Esfera do Processo Coletivo na Busca da Promoção do Interesse Público Primário .......................................................... 49

Capítulo 3. Ação Civil Pública como Meio Processual para Concretização do Acesso ao Serviço de Saneamento Básico pela Via Judicial e a Reserva do Possível 
3.1. Direito ao Saneamento Básico e Controle de Políticas Públicas 53

3.2. Direitos Sociais Prestacionais e a Reserva do Possível ....................... 58

3.3. Critérios: Ponderação, Razoabilidade e Proporcionalidade ................. 60

3.4. Controle Jurisdicional de Políticas Públicas, via Ação Civil Pública, envolvendo o Saneamento Básico: Análise de Decisões Judiciais .............. 63 3.4.1. Exequibilidade das Decisões Judiciais ......................................... 76

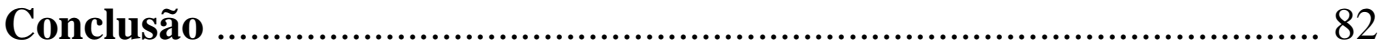

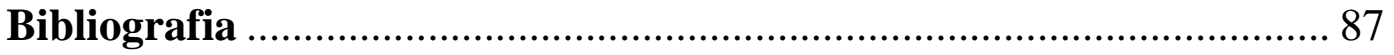




\section{INTRODUÇÃO}

A presente monografia visa analisar a ação civil pública enquanto instrumento para concretização de políticas públicas no âmbito do saneamento básico e sua relação com o meio ambiente equilibrado. Para tanto, aborda-se certos aspectos de decisões judiciais (especialmente quanto aos limites da intervenção em razão da teoria da reserva do possível, do orçamento público), as quais impõem prestações positivas ao Estado, cuja finalidade é a efetivação desse serviço público e direito social fundamental que é o saneamento básico. Em outras palavras, o objetivo deste trabalho é discorrer como e se a via judicial, através da ação civil pública, é o meio mais adequado e eficaz para promoção do direito ao saneamento básico, com o Poder Público figurando no polo passivo.

Ressalta-se, como delimitação do objeto de estudo, que não se pretende discutir pontos controvertidos e específicos do processo coletivo, tão somente questões essenciais. Também não se abordará a ação civil pública no âmbito específico do direito à saúde e do trabalho. Além disso, não será tratado o saneamento básico relativo ao manejo de resíduos sólidos, bem como questões específicas da legislação infraconstitucional, a qual compõe seu regime jurídico. Quanto à matéria ambiental, serão analisados aspectos gerais e apenas alguns pontos de intersecção do direito ambiental com o processo coletivo e o direito ao saneamento básico. Não se detalhará, por exemplo, a ação civil pública ambiental. Por fim, cumpre destacar que, em relação à teoria da reserva do possível, objetiva-se tão somente apresentar uma correlação da mesma com a temática em foco, não havendo, portanto, detalhamentos e discussões ampliadas sobre direito financeiro e orçamento público, em razão dos estritos limites monográficos.

No primeiro capítulo discorre-se sobre o saneamento básico enquanto serviço público essencial, um direito social fundamental. Explicita-se seu conceito, características e regime jurídico, seu fundamento constitucional, as 
competências dos entes federativos e sua previsão na legislação infraconstitucional. Outro ponto abordado, refere-se à relação entre o mínimo existencial e o direito ao saneamento básico. No segundo capítulo, discutese, brevemente, questões atinentes à tutela coletiva e à ação civil pública, tais como natureza dos direitos envolvidos, objeto e legitimados. Traça-se, assim, um contorno geral e necessário para, posteriormente, abordar as decisões judiciais em matéria de saneamento básico. Já no capítulo três, são traçados os limites da ação judicial, os efeitos das decisões em matéria de saneamento e a relação com os recursos públicos e a separação dos poderes.

A base metodológica consiste na apresentação do posicionamento doutrinário sobre o tema através da utilização de periódicos científicos e livros, bem como a análise jurisprudencial. Sendo assim, percebe-se que o foco deste trabalho é abordar a ação civil pública na defesa da ordem jurídica, no estrito âmbito do direito ao saneamento básico, analisando as repercussões das decisões judiciais que condenam a administração pública à efetivação de políticas públicas na esfera do saneamento, especificamente quanto a viabilidade da via judicial, critérios de julgamento que devem ser adotados e as restrições de sua execução em razão da incidência da teoria da reserva do possível.

Pretende-se, por fim, demonstrar que o processo coletivo, via ação civil pública, consiste num meio adequado para a tutela do direito ao saneamento básico em relação aos pleitos por efetivação de políticas públicas nesta área. Contudo, concomitantemente, alerta-se para certos aspectos controvertidos e dificuldades, decorrentes da reserva do possível, para a concretização desse direito através de imposições judiciais ao poder executivo, contestando, assim, a real eficácia das decisões. Tal fato pode representar um risco à sua exequibilidade e consequente realização dos serviços públicos e obras de infraestrutura que proporcionem melhores condições de vida à população. 


\section{Capítulo 1. Saneamento Básico: Aspectos Gerais}

\subsection{Conceito de Saneamento Básico}

O saneamento básico consiste na adequada prestação de serviços públicos essenciais à vida e saúde humanas e à preservação ambiental, resultado da associação entre investimentos e procedimentos técnicoestruturais, bem como no resultado da promoção de políticas públicas pelo Estado para, por exemplo, a prevenção de doenças e controle da poluição e da salubridade ambiental. Conforme definido no artigo $3^{\circ}$ da Lei Federal 11.445/2007, saneamento básico é o “conjunto de serviços, infra-estruturas e instalações operacionais de abastecimento de água potável; esgotamento sanitário; limpeza urbana e manejo de resíduos sólidos."

Ou seja, é um serviço público prestado a partir de ações integradas e interdependentes cuja complexidade, em razão da tecnicidade, amplitude e custos econômico-financeiros das obras de engenharia e dos serviços prestados, demanda articulação permanente do Estado, em cooperação com a sociedade civil, para sua efetivação. ${ }^{1}$ Em suma, são atividades atinentes ao abastecimento de água potável, esgotamento sanitário, limpeza urbana e manejo de resíduos sólidos, drenagem e manejo das águas pluviais. ${ }^{2}$

O conceito de saneamento é multifacetado, há nuances no âmbito da saúde pública, com caráter preventivo, de higiene e salubridade, do direito ambiental associado ao equilíbrio ecológico, e do direito à cidade hígida e sustentável, por exemplo. Nesse sentido, os artigos $2^{\circ}$ e $3^{\circ}$ da Lei 6938/81 demonstram a importância do saneamento básico no âmbito da Política Nacional do Meio Ambiente para evitar a poluição ambiental e assegurar o bem-estar humano, através do controle de elementos ambientais que podem

\footnotetext{
${ }^{1}$ MACHADO, Paulo Affonso Leme. Direito ambiental brasileiro. $22^{a}$ edição. São Paulo: Malheiros, 2014, p. 676-677.

2 BARROSO, Luis Roberto. Saneamento básico: competências constitucionais da União, Estados e Municípios. REDAE, Salvador, Instituto Brasileiro de Direito Público, no 11, 2007. p. 1-2.
} 
causar malefícios ao ser humano, nos aspectos físico, mental ou social. No artigo $2^{\circ}$ determina-se uma Política direcionada à defesa do meio ambiente, bem de uso coletivo, como forma de assegurar a qualidade e dignidade da vida e promover o desenvolvimento socioeconômico. Já o artigo $3^{\circ}$, III, alíneas a e d da referida lei define, a poluição ambiental como "degradação da qualidade ambiental resultante de atividades que direta ou indiretamente; prejudiquem a saúde, a segurança e o bem-estar da população; (...) afetem as condições estéticas ou sanitárias do meio ambiente".

A implementação do saneamento básico, portanto, é indispensável para garantia das condições mínimas de existência, de dignidade humana, de saúde pública, desenvolvimento socioeconômico e melhoria da qualidade de vida, há a presença de grande interesse social. Vê-se, assim, a estreita ligação dessas atividades com os direitos humanos, sendo pressuposto para efetivação de diversos direitos sociais e individuais, inclusive fundamentais, contemplados no ordenamento jurídico brasileiro. Logo, como consubstancia-se numa meta coletiva e essencial à vida humana e ao meio ambiente, é evidente a existência do interesse público primário e o dever do Estado, via prestações positivas, na promoção desse direito social. ${ }^{3}$

Ante o exposto, nota-se a dificuldade de reduzir a compreensão de saneamento à prestação de serviços públicos de natureza econômica, como apenas investimentos em infraestrutura, sujeitos à lógica de mercado. Está, na realidade, presente o interesse público primário, ou seja, necessidades essenciais da coletividade, as quais impõem especial tutela do Estado. São políticas sociais indispensáveis, por exemplo, à manutenção do meio ambiente ecologicamente equilibrado e à saúde pública. Desse modo, é possível caracterizá-lo como um direito social. ${ }^{4}$

\footnotetext{
${ }^{3}$ SARLET, Ingo Wolfgang. A eficácia dos direitos fundamentais. 12. ed. rev. e atual. Porto Alegre: Livraria do Advogado, 2015, p. 265-275.

${ }^{4}$ KRELL, Andreas Joachim. Realização dos direitos fundamentais sociais mediante controle judicial da prestação dos serviços públicos básicos: (uma visão comparativa). Revista de Informação Legislativa, Brasília vol. 36, n 144, 1999. p. 246-249.
} 


\subsection{Serviço Público e Saneamento Básico}

Em virtude da reconhecida dificuldade doutrinária quanto à conceituação dos serviços públicos, será apresentada a noção estrita, mais pacífica e objetiva a seu respeito. Segundo José dos Santos Carvalho Filho, "serviço público é toda atividade prestada pelo Estado ou por seus delegados, basicamente sob regime de direito público, com vistas à satisfação de necessidades essenciais e secundárias da coletividade". ${ }^{5}$

Maria Sylvia Zanella Di Pietro, por sua vez, define serviço público como "toda atividade material que a lei atribui ao Estado para que a exerça diretamente ou por meio de seus delegados, com o objetivo de satisfazer concretamente às necessidades coletivas, sob regime jurídico total ou parcialmente público". ${ }^{6}$

Já a Lei 13.460/2017, em seu art. $2^{\circ}$, II define serviço público como "atividade administrativa ou de prestação direta ou indireta de bens ou serviços à população, exercida por órgão ou entidade da administração pública".

Os serviços públicos constituem um dos principais objetivos do Estado, nem na hipótese de delegação o serviço perde sua natureza pública, o titular permanece sendo o Estado. Vale destacar a divisão entre os serviços públicos econômicos, espécie de atividade econômica, e os sociais. Pela Constituição Federal, no artigo 175, a titularidade é do Estado, o qual poderá delegar a prestação do serviço público, no caso do saneamento básico, de interesse primário. Além disso, conforme explica Di Pietro ${ }^{7}$, segundo o artigo 173 da Constituição brasileira, o Estado atua subsidiariamente na exploração de atividade econômica.

\footnotetext{
${ }^{5}$ CARVAlHO FILHO, José dos Santos. Manual de Direito Administrativo. $27^{\mathrm{a}}$ edição. São Paulo: Atlas, 2014, p. 329.

${ }^{6}$ DI PIETRO, Maria Sylvia Zanella. Direito administrativo. $30^{\mathrm{a}}$ edição. Rio de Janeiro: Forense, 2017, p. 139.

${ }^{7}$ Ibid. p. 138-142.
} 
Enquanto serviço público de caráter eminentemente social, o saneamento possui como princípios $^{8}$ a universalidade, vez que deve alcançar a toda coletividade, de forma isonômica; a continuidade, pois sua prestação não pode ser interrompida, salvo nas estritas hipóteses legais, ou seja, por razões de ordem técnica, manutenção da segurança das instalações ou pelo inadimplemento do usuário, em virtude do interesse coletivo; a modicidade remuneratória, seja por taxa ou tarifa, o usuário do serviço deve ser onerado o mínimo possível. Além desses, destaca-se o princípio da atualidade, que significa a necessidade de contínuo aprimoramento técnico, atualização dos meios empregados para disponibilização e execução do serviço, de modo a atingir, por exemplo, o princípio da eficiência e as necessidades dos usuários; bem como a participação da população no processo - pela presença nas etapas de discussão e execução das políticas públicas - e a cortesia, ou seja, o tratamento cordial dispensado aos cidadãos-usuários, como ensina José dos Santos Carvalho Filho. ${ }^{9}$

Quanto às características desses serviços, sua forma de prestação pode ocorrer diretamente pelo Estado ou indiretamente, ou seja, ser realizado por um delegatário que irá prestar o serviço, via concessão ou outro contrato administrativo, não por convênio ou outro termo de natureza precária ${ }^{10}$. Daí, percebe-se que tal atividade é delegável, ou seja, a execução dos serviços não é, obrigatoriamente, realizada de forma exclusiva pela Administração Pública, podendo haver a presença da iniciativa privada. Cabe ressaltar, contudo, que os investimentos em infraestrutura, precedentes à prestação e manutenção dos serviços, envolvem obras de grande porte e elevado custo financeiro.

\footnotetext{
${ }^{8}$ Conforme determina o artigo $6^{\circ}, \S 1^{\circ}$ da Lei $8987 / 95$ no qual se estabelece, sob regime de concessão ou permissão, que serviço público adequado é "o que satisfaz as condições de regularidade, continuidade, eficiência, segurança, atualidade, generalidade, cortesia na sua prestação e modicidade das tarifas."

${ }^{9}$ CARVALHO FILHO, José dos Santos. Manual de Direito Administrativo. $27^{a}$ edição. São Paulo: Atlas, 2014, p. 339-349.

${ }^{10}$ Ver item 1.4, no qual será explicitado o tema a partir da análise do Decreto no 7217/2010.
} 
Di Pietro ${ }^{11}$ explica que há, em geral, a presença única do Estado nessa fase ou, então, pode haver a celebração de Parcerias Público-Privadas. Essa atividade pode ser prestada de forma centralizada, no caso de contar apenas com a presença do Estado, ou descentralizada, quando o poder público transfere a titularidade por outorga, por lei a entidades da Administração Pública, ou a execução por delegação, transferência via concessão.

O saneamento básico é, portanto, um serviço público essencial, um conjunto de intervenções elementares, indispensáveis para o desenvolvimento humano vez que, em razão do interesse público primário configurado, os direitos relacionados e afetos à questão, são atrelados às principais demandas sociais. O seu regime, assim, é de direito público. Ainda que se trate de hipótese de delegação, haverá predominância do interesse público. Compete ao Estado exercer o poder de polícia administrativo e o dever de fiscalizar o cumprimento das atividades associadas ao saneamento básico.

Além disso, como explica José dos Santos Carvalho Filho ${ }^{12}$, são serviços de utilidade pública porque direcionados à população, à fruição direta pelos indivíduos, atingindo a toda coletividade, indistinta e indeterminadamente. Ressalta-se, ainda, a integralidade das ações, ou seja, um serviço depende do outro para ser efetivado realmente, são interdependentes. Por fim, quanto à noção de serviço público de saneamento básico vale destacar a previsão do artigo $2^{\circ}$, incisos V e XI do Decreto $\mathrm{n}^{\circ}$ 7217/2010, in verbis:

"Art. 2 ${ }^{\circ}$ Para os fins deste Decreto, consideram-se: (...) V - prestação de serviço público de saneamento básico: atividade, acompanhada ou não de execução de obra, com objetivo de permitir aos usuários acesso a serviço público de saneamento básico com características e padrões de qualidade determinados pela legislação, planejamento ou regulação; (...) XI - serviços públicos de saneamento básico: conjunto dos serviços públicos de manejo de resíduos sólidos, de limpeza urbana, de abastecimento de água, de esgotamento sanitário e de drenagem e manejo de

\footnotetext{
${ }^{11}$ DI PIETRO, Maria Sylvia Zanella. Direito administrativo. $30^{\mathrm{a}}$ edição. Rio de Janeiro: Forense, 2017, p. 146-149.

${ }^{12}$ CARVALHO FILHO, José dos Santos. Manual de Direito Administrativo. $27^{a}$ edição. São Paulo: Atlas, 2014, p.332.
} 
águas pluviais, bem como infraestruturas destinadas exclusivamente a cada um destes serviços."

\title{
1.3. Saneamento Básico enquanto Direito Social
}

Antes de estabelecer uma correlação com o saneamento básico, é preciso definir o conceito de direitos fundamentais sociais. Nesse sentido, segundo José Afonso da Silva:

\begin{abstract}
"Os direitos fundamentais são uma expressão que se refere a princípios que resumem a concepção de mundo e informam a ideologia política de cada ordenamento jurídico, é reservada para designar, no nível do direito positivo, aquelas prerrogativas e instituições que ele concretiza em garantias de uma convivência digna, livre e igual de todos. No qualificativo fundamentais, acha-se a indicação de que se trata de situações jurídicas sem as quais a pessoa humana não se realiza, não convive e, às vezes, nem mesmo sobrevive; fundamentais da pessoa humana no sentido de que a todos, por igual, devem ser, não apenas formalmente reconhecidos, mas concreta e materialmente efetivados. (...)

Os direitos sociais são compreendidos como dimensão dos direitos fundamentais da pessoa humana, são prestações positivas proporcionadas pelo Estado, direta ou indiretamente, enunciadas em norma constitucionais, que possibilitam melhores condições de vida aos mais fracos, direitos que tendem a realizar a igualização de situações sociais desiguais. São, portanto, direitos que se ligam ao direito de igualdade. Valem como pressupostos do gozo dos direitos individuais na medida em que criam condições materiais mais propícias ao auferimento da igualdade real, o que, por sua vez, proporciona condição mais compatível com o exercício efetivo da liberdade." 13
\end{abstract}

Os direitos sociais são direitos de $2^{\mathrm{a}}$ geração, visam à isonomia material, a redução das desigualdades, bem-estar, justiça social e, assim, requerem prestações positivas, para fruição de direitos fundamentais. Demandam investimentos e recursos, impondo um dever ao Estado Democrático de Direito, conforme os artigos 6º 193 da Constituição Federal de 1988. Em geral, consubstanciam normas programáticas constitucionais as quais, direcionadas aos entes da federação e aos três poderes, determinam objetivos e propósitos do Estado. ${ }^{14}$

\footnotetext{
${ }^{13}$ SILVA, José Afonso da Silva. Curso de Direito Constitucional Positivo. $37^{\mathrm{a}}$ edição. São Paulo: Malheiros, 2014, p. 180. E p. 288-289

${ }^{14}$ SARLET, Ingo Wolfgang. A eficácia dos direitos fundamentais. 12. ed. rev. e atual. Porto Alegre: Livraria do Advogado, 2015. p. 75-79
} 
Ressalta-se que, apesar de serem previsões gerais, as mesmas não são puramente abstratas, ou seja, possuem efeitos normativos concretos, de modo que o Legislativo deve editar leis a seu respeito e a Administração Pública executar políticas públicas na área, sob pena de intervenção do Judiciário, uma vez provocado, em caso de omissão ou inadequada prestação de serviços, para sua concretização, fato que evidencia sua aplicabilidade direta. Ou seja, conforme Krell ${ }^{15}$, ainda que o interprete da Constituição tenha certa autonomia e liberdade de conformação (discricionariedade, juízo de conveniência e oportunidade), quando houver alguma violação clara à Constituição (zona de certeza positiva) o Judiciário poderá ser provocado, pela via processual, para que seja garantida a realização do serviço público de saneamento básico, sem que isso signifique violação ao princípio constitucional da separação dos poderes. Contudo em razão dos limites orçamentários e aspectos federativos, essa questão ainda suscita controvérsias no âmbito doutrinário e jurisprudencial.

Os direitos fundamentais, por sua vez, como alertado por Sonia Aparecida de Carvalho e Luiz Gonzaga Silva Adolfo ${ }^{16}$, estão atrelados ao núcleo de direitos indispensáveis, direito à saúde, meio ambiente equilibrado, educação e moradia, por exemplo. Ou seja, relacionam-se às condições mínimas de existência e vida dignas. Enquanto conjunto, constituem um valor inerente à pessoa humana, seja no âmbito individual, como no social. São, assim, um dos objetivos do Estado brasileiro, conforme os artigos $1^{\circ} \mathrm{e}$ 3º ambos da Constituição Federal de 1988.

Diante do exposto, resta evidente a necessária associação dos serviços públicos de saneamento básico à garantia e efetivação de inúmeros direitos sociais fundamentais, integrantes do mínimo existencial, um feixe de direitos indispensáveis à dignidade humana, tais como acesso à água potável,

\footnotetext{
${ }^{15}$ KRELL, Andreas Joachim. Realização dos direitos fundamentais sociais mediante controle judicial da prestação dos serviços públicos básicos: (uma visão comparativa). Revista de Informação Legislativa, Brasília vol. 36, nº 144, 1999. p. 240-242.

${ }^{16}$ DE CARVALHO, Sonia Aparecida; ADOLFO, Luiz Gonzaga Silva. $O$ direito fundamental ao saneamento básico como garantia do mínimo existencial social e ambiental. Revista Brasileira de Direito, Passo Fundo, v. 8, n. 2, p. 6-37, out. 2012. p. 9-13.
} 
moradia adequada e saúde. Como já fora exposto até o presente momento, as ações na área sanitária são pré-condições, intervenções basilares para a possibilidade de fruição de direitos constitucionalmente previstos, sejam os mesmos individuais ou coletivos.

\subsection{Regime Jurídico do Saneamento Básico}

Neste tópico, pretende-se apenas apresentar brevemente as principais leis e atos normativos que constituem o marco jurídico acerca do saneamento básico. A Lei Federal n ${ }^{\circ}$ 11.445/2007 estabelece as diretrizes nacionais para o saneamento básico. É, assim, a principal referência legislativa infraconstitucional para a matéria. Além de definir princípios setoriais ${ }^{17} \mathrm{e}$ diversos conceitos, como de saneamento básico e os tipos de serviços públicos abrangidos, a referida lei dispõe sobre o exercício da titularidade do saneamento, estabelecendo critérios de regulação, condições e parâmetros de atuação (como a imperiosa elaboração de planos de saneamento básico, vide art. $\left.9^{\circ}, \mathrm{I}\right)$, bem como a prestação regionalizada desses serviços, quando um único prestador atende mais de um Município, havendo uniformidade de planejamento e regulação dos serviços, segundo o seu art. 14. Também aborda aspectos econômicos sociais e técnicos, assim como a possibilidade de participação dos cidadãos no processo, a fim de haver o controle social sobre as atividades. Institui-se a política federal de saneamento básico, atendendo às exigências da constituição quanto às competências da União, cria-se o PNSB - Plano Nacional de Saneamento Básico, conforme o art. 52, e se estabelece como os recursos serão distribuídos e os objetivos da União sobre essa política pública.

\footnotetext{
$17 \mathrm{O}$ artigo $2^{\circ}$ da Lei 11445/2007 elege como princípios fundamentais dos serviços públicos de saneamento básico, dentre outros, a universalização do acesso, a integralidade de todas as atividades, a transparência nas ações, a eficiência e o controle social, possibilitando à sociedade avaliar a discricionariedade do agente público e, quando necessário, intervir na promoção dessa política pública pela via legalmente adequada. Além disso, afirma-se, no inciso VI do referido artigo, a relação diretamente proporcional entre melhoria das condições de saneamento básico com diversas causas de significativo interesse social, tais como desenvolvimento urbano e regional, habitação, combate e erradicação da pobreza, proteção ambiental e promoção da saúde.
} 
Vale, ainda, destacar conforme o artigo $4^{\circ}$ do aludido diploma legal, que "os recursos hídricos não integram os serviços públicos de saneamento", sendo que sua utilização na prestação dos serviços poderá depender, conforme o caso, da outorga de direito de uso, segundo dispõe a lei federal 9433/97. O artigo 10 da Lei 11.445/2007, por sua vez, determina que para delegação dos serviços não poderão ser realizados convênios ou atos similares de natureza precária, mas sim contratos ou instrumentos que garantam estabilidade e segurança à relação jurídica estabelecida. Por fim, o artigo 16 da referida Lei afirma, in verbis, que "a prestação pode ocorrer por órgão, autarquia, fundação de direito público, consórcio público, empresa pública ou sociedade de economia mista estadual, do Distrito Federal, ou municipal, ou por empresa a que se tenham concedido os serviços".

Outro ato normativo relevante é o Decreto $\mathrm{n}^{\circ} 7.217 / 2010$, responsável por regulamentar a Lei $\mathrm{n}^{\circ} 11.445 / 2007$, proporcionando maior eficácia a mesma e segurança jurídica às questões atinentes à temática. Dentre os 70 artigos que o compõem, destaca-se os artigos $2^{\circ}$ e $3^{\circ}$ os quais, respectivamente, conceituam as expressões recorrentes no âmbito do saneamento, como titularidade do serviço e prestador, e explicitam princípios norteadores do sistema, como a universalidade, o controle social, a eficiência e a transparência. Do artigo $4^{\circ}$ ao 17 são discriminados especificamente as atividades associadas ao saneamento básico. Posteriormente, determina-se no artigo 18 a não inclusão dos recursos hídricos no conceito de serviços públicos de saneamento, embora devam ser observadas as normas para uso sustentável da água. Estabelece, também, a necessidade de outorga de direito de uso da água com o ente que detém o domínio do recurso, bem como a exigência de prévio licenciamento ambiental para realização das intervenções e atividades. Detalha-se, ainda, o exercício da titularidade do serviço, a questão do planejamento e regulação, previstas no artigo 23 ao 33 .

No artigo 34 do Decreto $n^{\circ} 7.217 / 2010$, estabelece-se que o controle social dos serviços de saneamento pode ocorrer, por exemplo, através de debates e audiências públicas, bem como na participação em etapas de 
deliberação e do planejamento das políticas. Todos estes são instrumentos que forneçam à população informações, garantindo maior publicidade e legitimidade democrática à execução dos serviços. Em relação à titularidade, ressalta-se o art. 38 do ato normativo supracitado, que trata das modalidades de seu exercício. O referido dispositivo dispõe, in verbis, que:

\begin{abstract}
“Art. 38. O titular poderá prestar os serviços de saneamento básico: I - diretamente, por meio de órgão de sua administração direta ou por autarquia, empresa pública ou sociedade de economia mista que integre a sua administração indireta, facultado que contrate terceiros, no regime da Lei no 8.666, de 21 de junho de 1993, para determinadas atividades; II - de forma contratada: a) indiretamente, mediante concessão ou permissão, sempre precedida de licitação na modalidade concorrência pública, no regime da Lei no 8.987/1995; ou b) no âmbito de gestão associada de serviços públicos, mediante contrato de programa autorizado por contrato de consórcio público ou por convênio de cooperação entre entes federados, no regime da Lei no 11.107/2005;"
\end{abstract}

Por último, são detalhados os aspectos econômicos financeiros, as diretrizes e objetivos, o financiamento das políticas na área, vide artigos 55 e 56, e os planos de saneamento da União, em relação aos quais preconiza-se e prioriza-se a formulação e execução de políticas públicas integradas a fim de promoção do desenvolvimento econômico-social, conforme artigo 48 inciso I, proteção ambiental, combate à pobreza, defesa da saúde e melhoria da qualidade de vida, por meio do saneamento básico.

Outra Lei que guarda relação com o saneamento é a Lei Federal $n^{\circ}$ 8.080/1990, a qual dispõe sobre as condições para fomentar e preservar a saúde, assim como a estruturação dos serviços a ela associados, com destaque para o artigo $2^{\circ}$ do aludido ato normativo. Este dispositivo afirma que a saúde é um direito fundamental do homem e que cabe ao Estado assegurar os requisitos necessários para seu exercício pleno. Desse modo é dever do Estado executar políticas econômico-sociais que, por exemplo, reduzam os riscos de doenças. Alerta-se, ainda, que o mesmo dispositivo explicita que a garantia da saúde é um dever não adstrito apenas ao Estado, mas compartilhado por toda sociedade. Já no artigo $3^{\circ}$, a referida lei afirma a relação diretamente proporcional entre o nível de saúde com 
desenvolvimento econômico e social do País. Esse artigo $3^{\circ}$ da Lei 8080/90 insere como pressupostos para melhoria dos níveis de saúde, por exemplo, "a alimentação, a moradia, o saneamento básico, o meio ambiente, o trabalho e o acesso a bens e serviços essenciais". Evidente, portanto, que o serviço público de saneamento básico é pressuposto para a melhoria da saúde pública e, consequentemente, do desenvolvimento socioeconômico do País.

Também é preciso mencionar a Lei 10257/2001, denominada Estatuto da Cidade, e que prevê em seu artigo $2^{\circ}$, I, entre outras coisas, o direito ao saneamento ambiental, à infra-estrutura urbana e aos serviços públicos como elementos indissociáveis à garantia do direito a cidades sustentáveis, uma diretriz da política urbana cujo objetivo é promover a função social da cidade. Através da rede de serviços públicos de saneamento prestados com observância aos princípios elencados no artigo $2^{\circ}$ da Lei 11/445/2007, assegurar-se-á uma melhor qualidade de vida à sociedade e, consequentemente, a possibilidade de maximizar a fruição de tantos outros direitos relacionados ao meio ambiente urbano, tais como trabalho, moradia, lazer e transporte. Já no inciso XVIII do artigo $2^{\circ}$ da Lei 10257/2001 conferese, no âmbito das políticas públicas urbanas, tratamento prioritário às obras e edificações de infraestrutura relacionadas ao saneamento. ${ }^{18}$

No que tange à Constituição Federal de 1988, ressalta-se o artigo $1^{\circ}$, III, no qual a dignidade da pessoa humana é alçada a fundamento da República. No art. $3^{\circ}$, incisos I, II e III, são considerados objetivos do Estado uma sociedade livre, justa e solidária, o desenvolvimento nacional, a erradicação da pobreza e marginalização, e a redução das desigualdades sociais e regionais. $\mathrm{O}$ art. $6^{\circ}$, por sua vez, elenca diversos direitos, tais como direito a saúde, moradia, previdência social, e classifica-os como sociais.

\footnotetext{
${ }^{18}$ Ou seja, a lei expressamente condiciona e vincula a atuação do administrador e legislador ao determinar a prioridade das políticas públicas relacionadas à concretização dos serviços públicos de saneamento na agenda política do Legislativo e do Executivo. Desse modo, consiste em parâmetro objetivo para o Judiciário aferir a legalidade dos atos da administração pública, inclusive quando envolver atos supostamente discricionários, afetos à conveniência e oportunidade, mas não apartados de observar as normas do ordenamento jurídico. Sobre esse assunto, tratar-se-á oportunamente no capítulo 3 .
} 
Estes direitos são intimamente relacionados ao saneamento básico.

Já no artigo 196, diz-se que através de serviços e políticas socioeconômicas, reduzindo o risco de doenças, por exemplo, o Estado deverá assegurar o direito à saúde, de forma isonômica e universal. Instituise uma noção de saúde preventiva, correlacionada com o saneamento básico e a seguridade social, com a ideia de não praticar ações que coloquem em risco a saúde pública e o meio ambiente. O 197, por sua vez, trata da importância, do relevo público dos serviços de saúde, os quais podem ser prestados diretamente ou por terceiros, indiretamente pelo setor privado, mas sua regulamentação, fiscalização e controle são realizados apenas pelo Poder Público.

Logo depois, o art. 200, IV da Constituição Federal de 1988 afirma que compete ao sistema único de saúde a participação na elaboração de políticas e na execução de ações direcionadas ao saneamento básico. Outro ponto importante é o art. 225, no qual se prevê o direito ao meio ambiente ecologicamente equilibrado como direito coletivo, impondo um dever geral à sociedade para preservação e defesa do meio ambiente, algo absolutamente ligado à questão sanitária.

Além disso, no artigo $225, \S 1^{\circ}$, IV da $\mathrm{CRFB} / 88$ prevê-se a necessidade de realização de prévio licenciamento ambiental para execução de empreendimentos que gerem impacto ambiental. Sinteticamente, o licenciamento ambiental, cuja natureza jurídica é de autorização administrativa - ato temporário e que não gera direitos adquiridos -, consiste no exercício do poder de polícia preventivo através de um procedimento administrativo realizado junto ao órgão ambiental competente, no qual cumpre-se diversas determinações para que se possa efetivamente promover o empreendimento. Esse procedimento aplica-se às necessárias obras de infra-estrutura e à própria operação das atividades relacionadas ao saneamento básico. Isso evidencia o que a plena efetivação do direito ao saneamento ambiental envolve uma série de obrigações e procedimentos, os 
quais tornam a operação complexa e de significativo impacto orçamentáriofinanceiro para o Poder Público.

Na Constituição Federal, observa-se, também, o disposto nos incisos I, VI, VII, IX e X do caput e no parágrafo único do art. 23, para estabelecer normas de cooperação entre os entes de federação no âmbito das competências político-administrativas comuns, especificamente, quanto à questão da melhoria das condições de saneamento básico, defesa do meioambiente e combater às causas da pobreza, deveres estatais de âmbito econômico-social. Esta competência, ainda carente de regulamentação satisfatória, consiste na distribuição e compartilhamento dos ônus econômicos e operacionais, na prestação de serviços e atividades, pela União, Estados e Municípios. Não se define a titularidade, mas a possibilidade de ações conjuntas para melhor atendimento dos objetivos constitucionais. Há, ainda, a Lei Federal 9.433/1997, que institui a Política Nacional de Recursos Hídricos, sendo mais relevantes para a temática em questão os artigos 11 a 14, os quais dispõem sobre a outorga do direito de uso da água.

Cabe, por fim, destacar que a constituição federal afirma que o bemestar e a justiça social são fundamentos da ordem social, que compete concorrentemente à União, Estados e Distrito Federal, legislar sobre florestas, caça, pesca, fauna, conservação da natureza, defesa do solo e dos recursos naturais, proteção do meio ambiente e controle da poluição, vide art. 24, VI. Ressalta-se que a União, nesse caso, estabelece normas gerais, e sua competência não exclui a possibilidade de suplementação, da legislação, pelos Estados, conforme preconiza o artigo $24 \S \S 1^{\circ}$ e $2^{\circ}$. Quanto aos artigos centrais relativos às competências dos entes da federação, os artigos 23, 25, 30 e 241 da CRFB/88, estes serão apresentados e analisados no tópico seguinte.

\subsection{Competências dos Entes Federativos Brasileiros em Matéria de Saneamento Básico}


Os quatro principais artigos sobre saneamento na Constituição Federal são o 23 , IX, 30, V, 25, § $3^{\circ}$, e 200, IV. A principal discussão desse ponto está associada ao fato de que os serviços relacionados ao saneamento básico são, em regra, de predominância do interesse local, de titularidade do Município. De acordo com o artigo 30, I, II e V da Constituição Brasileira, in verbis, "compete aos Municípios legislar sobre assuntos de interesse local; suplementar a legislação federal e a estadual no que couber; organizar e prestar, diretamente ou sob regime de concessão ou permissão, os serviços públicos de interesse local, ...”. Contudo, nas regiões metropolitanas, aglomerações urbanas e microrregiões, não mais se cingem ao Município, devendo, pelo interesse regional, ser compartilhada a competência com o Estado, vide Leis Federais $\mathrm{n}^{\mathrm{o}} 13.089 / 2015$ e $\mathrm{n}^{\mathrm{o}}$ $10.257 / 2001 .{ }^{19}$

Inicialmente, é preciso mencionar que, embora a gestão dos recursos hídricos não faça parte dos serviços públicos de saneamento, é preciso saber qual ente, União Federal ou Estado, conforme o art. 20, III e VI da CRFB/88, possui a titularidade do domínio da água. Como regra, o responsável pela prestação do saneamento básico é o Município, ente que não possui domínio de recursos hídricos. Assim, o mesmo precisará obter a outorga de direito de uso com o detentor do recurso hídrico. Vale destacar que essa concessão, conforme previsão legal, é ato administrativo vinculado, ou seja, uma vez preenchidos os requisitos para a outorga, com base no art. 21, XIX CRFB/88, não pode o ente recusar-se a concedê-la, sob pena de intervenção judicial. ${ }^{20}$

Quanto às competências da União, cabe ao ente político nacional o estabelecimento de diretrizes e normas gerais no âmbito do saneamento, segundo o art. 21, XX e XIX da CRFB/88, bem como, na esfera da competência material comum do Executivo, dar suporte financeiro, técnico,

\footnotetext{
${ }^{19}$ BARROSO, Luis Roberto. Saneamento básico: competências constitucionais da União, Estados $e$ Municípios. Revista Eletrônica de Direito Administrativo Econômico (REDAE), Salvador, Instituto Brasileiro de Direito Público, no 11, 2007. p. 10-14.

${ }^{20}$ MARTINS, Ricardo Marcondes. Titularidade do serviço de saneamento básico. Revista de Direito Administrativo, Rio de Janeiro, v. 249, p. 171-198, set. 2008. p. 177-179.
} 
e, ainda, realizar a proteção do meio ambiente e controle da poluição, em cooperação com os Estados e os Municípios, de acordo com o art. 23, IX CRFB/88. Vale destacar a existência da Lei Complementar n 140/2011, que fixa normas para cooperação federativa, a fim de promoção do bem-estar e desenvolvimento sustentável em âmbito nacional. ${ }^{21}$ Além disso, à união, no art. 200, IV da CRFB/88 incumbe o planejamento e participação na execução mediante, por exemplo, o repasse de verbas. A União pode contribuir, também, estabelecendo critérios técnicos para definição do interesse local ou comum, bem como de outros conceitos e requisitos.

O artigo 241 da Constituição Federal de 1988, por sua vez, dispõe sobre a gestão associada dos serviços públicos, a cooperação dos entes para sua prestação. Isso pode ocorrer através de consórcios públicos de acordo com o art. $3^{\circ}$, II e o art. 24 da lei 11.107/2005, ou seja, pela instituição, em conjunto, de um ente encarregado pela execução e gerenciamento. ${ }^{22}$ Nessa hipótese, há uma divisão voluntária e parcial da competência originariamente atribuída ao titular do serviço de saneamento, havendo compartilhamento de encargos, serviços, pessoal e bens para a prestação dos serviços.

Conforme dispõe o art. 23, IX da Constituição Federal de 1988, a competência político-administrativa dos entes da federação (União, Estados e Municípios) é comum no âmbito do saneamento. Ou seja, a Constituição impõe a cooperação federativa como meio de promover ações positivas e conjuntas no âmbito da Administração Pública nas três esferas federativas em relação a essa matéria.

Já o artigo 24 da CRFB/88, prevê a competência concorrente para legislar. Tal competência aplica-se à União Federal, aos Estados Membros e ao Distrito Federal. Consiste na edição de normas, sobre a mesma matéria, por quaisquer destes entes, sendo que à União cabe elaborar as normas gerais, e, havendo legislação nacional, as normas estaduais, distritais e municipais

\footnotetext{
${ }^{21}$ CARVALHO FILHO, José dos Santos. Manual de Direito Administrativo. $27^{a}$ edição. São Paulo: Atlas, 2014, p. 334-337.

${ }^{22}$ MACHADO, Paulo Affonso Leme. Direito ambiental brasileiro. 22 $2^{\mathrm{a}}$ edição. São Paulo: Malheiros, 2014, p. 677-678.
} 
sejam com ela compatíveis e harmônicas. Os Municípios também podem legislar sobre tais matérias, pois com base no art. 30, incisos I e II da CRFB/88, os mesmos poderão suplementar a legislação dos demais entes federativos, desde que presente o interesse local.

Além disso, no âmbito municipal, com base na prevalência do princípio da predominância do interesse o Município, em razão do interesse local previsto no art. 30, $\mathrm{V}$ da CRFB/88, constitui-se como titular ordinário da competência privativa para execução dos serviços públicos de saneamento, tipicamente de natureza local, adstritos aos limites territoriais. ${ }^{23}$

Excepcionalmente, contudo, quando constatado o interesse comumregional, em decorrência do fenômeno da conurbação, ou na busca pela eficiência, por exemplo, essa responsabilidade é compartilhada com o Estado. Nas regiões metropolitanas, aglomerados urbanos e microrregiões a extensão dos efeitos extrapola o âmbito territorial, de interesse dos Municípios, conforme art. 25, parágrafo $3^{\circ}$ da CRFB/88. Desse modo, é importante realizar a análise da competência de forma casuística. Nesse sentido, o princípio da predominância do interesse orienta as competências constitucionais; a União possui interesse nacional-geral, os Estados, interesse regional, e os Municípios, interesse local. Contudo, em muitas situações não há uma clara fronteira entre esses domínios do interesse para fins de definição da titularidade da competência. Sobre a noção de predominância do interesse cabe destacar a seguinte comentário de Luis Roberto Barroso:

"A noção de predominância de um interesse sobre os demais implica a ideia de um
conceito dinâmico. Isto é: determinada atividade considerada hoje de interesse
predominantemente local, com a passagem do tempo e a evolução dos fenômenos
sociais, poderá perder tal natureza, passando para a esfera de predominância
regional e até mesmo federal. Uma série de fatores pode causar essa alteração:
desde a formação de novos conglomerados urbanos, que acabam fundindo
municípios limitrofes, até a necessidade técnica de uma çãa integrada de vários
municípios, para a realização do melhor interesse público. Também não é
impossível imaginar o processo inverso, diante de uma substancial alteração da
forma de ocupação populacional no território. Assim, todo o serviço público que
não esteja expressamente afetado a outro ente federativo e que possa ser

${ }^{23}$ MOREIRA NETO, Diogo de Figueiredo. Curso de Direito Administrativo. $16^{\mathrm{a}}$ edição. Rio de Janeiro: Forense, 2014, p.476-480. 
caracterizado como de predominante interesse local, relativamente ao interesse dos Estados e da União, será da competência dos Municípios. A regra vale, naturalmente, para os serviços afetos ao saneamento básico.

(...). É preciso fazer menção, por muito importante, que boa parte da doutrina, com razão, aplicando os critérios referidos acima à realidade das regiões metropolitanas, microrregiões ou aglomerações urbanas brasileiras, entende que o saneamento básico é um serviço comum, de titularidade do Estado. Não há, pois, atividades, serviços ou obras que, por natureza intrínseca, sejam considerados de exclusivo interesse local. Assim, por exemplo, os serviços de captação e tratamento de água para consumo público, tradicionalmente, são de interesse local, inscritos na competência do Município. Entretanto, esses mesmos serviços são inequivocamente de interesse comum numa região metropolitana devendo ser de competência regional e não do Município isolado. O mesmo serviço, conforme o enfoque, o lugar, o modo e as circunstâncias de sua prestação, será objeto de interesse local ou regional, dependendo do caso." 24

Ricardo Marcondes Martins ${ }^{25}$ explica que cooperação representa, na verdade, a cooperação entre os entes, não só através de recursos financeiros, mas pela teoria da troca do sujeito, que significa a substituição excepcional e temporária do ente titular para prestar o serviço, por outro (Município, Estado ou União, por exemplo), em decorrência de uma série de razões fáticas e jurídicas, uma vez que a troca pode ocorrer, por exemplo, pela omissão, incapacidade financeira ou prestação inadequada dos serviços pelo ente que possui a competência originária. Assim é possível, seja ao Ministério Público como ao próprio cidadão, requerer-se, judicialmente, a realização do serviço público por outro ente, configurando a troca de sujeito involuntária. Há, também, a troca voluntária, que ocorre quando o próprio titular requer o auxílio de outro ente para prestar o serviço em parceria, em comum acordo, de acordo com o art. 241 da CRFB/88.

Ressalta-se, no entanto, que para haver a troca do sujeito é preciso que certos pressupostos sejam preenchidos, de modo que a substituição total é transitória e não deve o ente, em plenas condições econômico-financeiras, requere-la. Ou seja, não há um completo juízo de conveniência e

\footnotetext{
${ }^{24}$ BARROSO, Luis Roberto. Saneamento básico: competências constitucionais da União, Estados e Municípios. Revista Eletrônica de Direito Administrativo Econômico (REDAE), Salvador, Instituto Brasileiro de Direito Público, nº 11, 2007. p. 11-12. E p.17.

${ }^{25}$ MARTINS, Ricardo Marcondes. Titularidade do serviço de saneamento básico. Revista de Direito Administrativo, Rio de Janeiro, v. 249, 2008. p. 184-186.
} 
oportunidade, de discricionariedade. ${ }^{26}$ Nesse sentido, destaca-se a importância de preservação da autonomia federativa e da repartição constitucional de competências dos entes, as competências exclusivas, privativas e as principiológicas, ou seja, comuns e concorrentes. Neste caso, especificamente, trata-se da integridade da autonomia municipal enfatizada, inclusive, no art. 18 da CRFB/88.

Com base no art. 25, parágrafo $3^{\circ}$ da Constituição Federal de 1988, o Estado poderá editar lei complementar para instituir a região metropolitana, aglomeração urbana ou microrregião - para tanto, conforme já mencionado, deverão estar presentes elementos para sua criação -, definindo quais serviços são de interesse comum, a cargo do estado, e quais são de competência do Município, locais. A integração, neste caso, é compulsória. Nessas regiões urbanas, as novas dinâmicas de circulação de pessoas e capital, as peculiaridades geográficas demandam uma abordagem diferenciada quanto à prestação dos serviços públicos. Um Município depende do outro, e suas ações afetam diretamente os demais, ou seja, através de cada gestão administrativa dos serviços públicos de saneamento básico eles atingem-se mutuamente, positiva ou negativamente. Assim, o Estado, em razão do interesse comum, organiza, planeja e executa funções públicas nestes agrupamentos de Municípios limítrofes.

Com efeito, os Municípios per si, nessas situações, não suportam toda a demanda da população, os processos tornam-se demasiado custosos e complexos, os limites territoriais não são mais perceptíveis faticamente. Nessas áreas, unificam-se os serviços a fim de racionalizar e viabilizar o planejamento e a execução adequada e eficiente de serviços públicos, há uma administração intermunicipal conectada, através do estado instituidor e gestor.

Desse modo, possibilita-se ao Estado promover a integração dos municípios afetados, há uma parceria com o mesmo para promoção dos serviços de saneamento básico, atendendo-se, assim, satisfatoriamente à

\footnotetext{
${ }^{26}$ Ibid. p. 191-192.
} 
população. Há, assim, um deslocamento de interesse do âmbito local para o regional. ${ }^{27}$ Por fim, destaca-se que o caráter compulsório não ferirá a autonomia municipal, desde que verificado o interesse comum-regional, conforme já mencionado.

\title{
1.6. Meio Ambiente Equilibrado e Direito Difuso ao Saneamento Básico
}

Ante ao exposto até o momento, faz-se necessário demonstrar, especificamente, a imbricação entre saneamento básico e meio ambiente. É evidente que a ausência do serviço público de saneamento básico acarreta, entre outras coisas, a poluição ambiental. Seja pela contaminação do solo e da água, como pela proliferação de doenças, ocorrência de deslizamentos de terra e enchentes. Sobre essa relação, cabe destacar o seguinte entendimento:

\begin{abstract}
"O problema do saneamento básico afeta a dignidade do ser humano com o meio natural. A qualidade ambiental deve ser reconhecida como elemento integrante do princípio da dignidade da pessoa humana, sendo fundamental ao desenvolvimento do ser humano e ao bem-estar existencial. A saúde humana depende dos serviços de saneamento básico como fatores determinantes as relações entre o meio ambiente e a saúde. As doenças causadas pelos problemas da falta de saneamento básico atingem especialmente, a população mais carente. Com isso, causa o aumento das desigualdades sociais, além de afrontar os direitos fundamentais sociais constitucionais e à dignidade da pessoa humana." ${ }^{28}$
\end{abstract}

Não é possível, portanto, dissociar o direito ao saneamento básico do direito ao meio ambiente ecologicamente equilibrado, previsto no caput do artigo 225 da Constituição Federal e inspirado no princípio 1 da declaração de Estocolmo ${ }^{29}$. Da leitura do referido dispositivo constitucional, extrai-se

\footnotetext{
${ }^{27}$ BARROSO, Luis Roberto. Saneamento básico: competências constitucionais da União, Estados e Municípios. Revista Eletrônica de Direito Administrativo Econômico (REDAE), Salvador, Instituto Brasileiro de Direito Público, $n^{\circ}$ 11, 2007. p. 9-10.

${ }^{28}$ DE CARVALHO, Sonia Aparecida; ADOLFO, Luiz Gonzaga Silva. $O$ direito fundamental ao saneamento básico como garantia do mínimo existencial social e ambiental. Revista Brasileira de Direito, Passo Fundo, v. 8, n. 2, p. 6-37, out. 2012. p. 8.

${ }^{29}$ Declaração de Estocolmo de 1972 proferida na conferência das Nações Unidas sobre o Meio Ambiente Humano. Princípio 1: O homem tem o direito fundamental à liberdade, à igualdade e ao desfrute de condições de vida adequadas em um meio ambiente de qualidade tal que lhe permita levar uma vida digna e gozar de bem-estar, tendo a solene obrigação de proteger e melhorar o meio
} 
que o meio ambiente é "bem de uso comum do povo e essencial à sadia qualidade de vida". A dicção do dispositivo indica que a preservação ambiental é um direito humano, fundamental e indisponível, ou seja, pertencente a toda coletividade e insuscetível de apropriação privada, vez que a vida e saúde plenos são dependentes do equilíbrio ecológico. ${ }^{30} \mathrm{~A}$ higidez desse direito de natureza difusa impõe à sociedade e ao Estado especial proteção, não apenas por sua fragilidade ante às ações humanas, como pelos incontáveis efeitos deletérios da poluição e degradação ambiental que afetam a sociedade e a biota (fauna e flora).

Outro direito intrínseco ao equilíbrio ecológico é o desenvolvimento sustentável, inserto na Declaração do Rio de Janeiro de 1992 e implicitamente previsto no artigo 225 da Constituição Federal. Sobre a referida Declaração do Rio de Janeiro de 1992, vale explicitar os seguintes dispositivos:

\begin{abstract}
"Princípio 3: O direito ao desenvolvimento deve ser exercido de modo a permitir que sejam atendidas equitativamente as necessidades de desenvolvimento e de meio ambiente das gerações presentes e futuras. Princípio 4: Para alcançar o desenvolvimento sustentável, a proteção ambiental constituirá parte integrante do processo de desenvolvimento e não pode ser considerada isoladamente deste. Princípio 5: Para todos os Estados e todos os indivíduos, como requisito indispensável para o desenvolvimento sustentável, irão cooperar na tarefa essencial de erradicar a pobreza, a fim de reduzir as disparidades de padrões de vida e melhor atender às necessidades da maioria da população do mundo." ${ }^{31}$
\end{abstract}

$\mathrm{O}$ desenvolvimento sustentável possui três aspectos essenciais. ${ }^{32} \mathrm{O}$ primeiro, é estabelecer um equilíbrio entre desenvolvimento econômico e preservação ambiental. Ou seja, é preciso criar métodos de produção, consumo e descarte que sejam o menos nocivo possível ao meio ambiente. $\mathrm{O}$

ambiente para as gerações presentes e futuras. Disponível em: https://bit.ly/2wS3FcW. Acesso em: 17 de maio de 2018.

30 MACHADO, Paulo Affonso Leme. Direito ambiental brasileiro. 22 $2^{\mathrm{a}}$ edição. São Paulo: Malheiros, 2014. p. 61-63, 152.

${ }^{31}$ Declaração do Rio de Janeiro de 1992 no âmbito da conferência das Nações Unidas sobre o meio ambiente e desenvolvimento humano. Disponível em: http://www.onu.org.br/rio20/img/2012/01/rio92.pdf. Acesso em: 17 de maio de 2018.

32 MACHADO, Paulo Affonso Leme. Direito ambiental brasileiro. $22^{\mathrm{a}}$ edição. São Paulo: Malheiros, 2014. p. 69-71. 
segundo ponto consiste na preocupação com as gerações futuras, no reconhecimento de direitos das novas gerações. É a lógica da equidade intergeracional, necessidade de equilíbrio entre economia e preservação ambiental, de modo a reconhecer que se nada for feito para reverter o quadro atual de desenvolvimento insustentável, isso impediria a vida o atingimento das necessidades básicas das próximas gerações, as quais encontrariam o meio ambiente degradado.

O terceiro elemento consiste na necessidade de erradicação da miséria, um fator essencial para redução da poluição e degradação ambiental. Quanto a este ponto, a plena efetivação do direito e a prestação de serviços públicos relacionados ao saneamento básico faz-se imprescindível para diminuir as desigualdades sociais, erradicar a miséria e, por conseguinte, promover o desenvolvimento sustentável, vide art. $3^{\circ} \mathrm{CRFB} / 88$.

Cumpre destacar, ainda, como princípios decorrentes do equilíbrio ecológico, a prevenção e a precaução. Inscrito no artigo 225 da Constituição Federal e previsto como princípio 18 da Declaração de Estocolmo de $1972^{33}$, a prevenção determina que, em havendo certeza científica de que uma determinada atividade causa degradação ambiental, deve-se sopesar seus benefícios e malefícios para a sociedade a fim de, ou proibir totalmente sua prática, ou permitir sua realização, mas mitigando o máximo possível o nocivo impacto ambiental dela decorrente. O princípio da precaução, por sua vez, está presente na Declaração do Rio de Janeiro de $1992^{34}$ e prevê que a ausência de certeza científica quanto aos impactos ambientais decorrentes de determinada atividade não justifica a postergação ou não realização de

\footnotetext{
${ }^{33}$ Declaração de Estocolmo de 1972 proferida na conferência das Nações Unidas sobre o Meio Ambiente Humano. Princípio 18: Como parte de sua contribuição ao desenvolvimento econômico e social deve-se utilizar a ciência e a tecnologia para descobrir, evitar e combater os riscos que ameaçam o meio ambiente, para solucionar os problemas ambientais e para o bem comum da humanidade. Disponível em: Acesso em:

${ }^{34}$ Declaração do Rio de Janeiro de 1992 no âmbito da conferência das Nações Unidas sobre o meio ambiente e desenvolvimento humano. Princípio 15: Com o fim de proteger o meio ambiente, o princípio da precaução deverá ser amplamente observado pelos Estados, de acordo com suas capacidades. Quando houver ameaça de danos graves ou irreversíveis, a ausência de certeza científica absoluta não será utilizada como razão para o adiamento de medidas economicamente viáveis para prevenir a degradação ambiental. Disponível em: Acesso em:
} 
mediadas que visem evitar ou minimizar tal ameaça, pois ante o risco e incerteza da poluição prevalece a proteção ao meio ambiente, ou seja, in dubio pro natura. ${ }^{35}$

Diante do exposto até aqui, percebe-se que a preservação ambiental é um direito indisponível e imprescritível, de terceira geração, da ordem dos direitos difusos, que demanda da sociedade e do Estado um dever de proteção ao meio ambiente. Em relação às gerações de direitos é preciso fazer uma breve explanação. Os direitos de $1^{\mathrm{a}}$ geração são tipicamente direitos de liberdade, de cunho negativo e formal. Ou seja, são direitos individuais, de resistência e oposição ao Estado que geram a este um dever de não fazer. São exemplos os direitos civis e políticos, a legalidade e igualdade formal.

Os direitos de $2^{\mathrm{a}}$ geração, por sua vez, visam a isonomia material, real e possuem natureza positiva. Significa que, enquanto liberdades concretas, exigem do Estado prestações positivas e ações afirmativas e fim de assegurar a igualdade entre os indivíduos. São exemplos os direitos sociais como a saúde, educação, trabalho e moradia. A isonomia material consiste na discriminação consciente, em prol da equidade de condições e oportunidades entre as pessoas. Assim, despende-se, com razoabilidade e proporcionalidade, um tratamento desigual a indivíduos que se encontram em situações (sociais, econômicas, jurídicas) diferentes, na medida de suas desigualdades, a fim de atingir a igualdade concreta entre eles, a equidade.

Já os direitos de $3^{\mathrm{a}}$ geração, denominados direitos de fraternidade e solidariedade, demandam, da sociedade e do Estado, deveres para assegurálos. Consistem em direitos de titularidade difusa, como no caso do meio ambiente e do patrimônio cultural. Sobre essa classificação acima exposta vale destacar a seguinte ementa da decisão do Supremo Tribunal Federal no Mandado de Segurança ${ }^{\circ} 22164^{36}$ :

\footnotetext{
35 MACHADO, Paulo Affonso Leme. Direito ambiental brasileiro. 22 $2^{\mathrm{a}}$ edição. São Paulo: Malheiros, 2014. p. 94-96.

${ }^{36}$ STF, Mandado de Segurança n ${ }^{\circ} 22164$, Rel. Min. Celso de Mello, Tribunal Pleno, Brasília (DF), 30 de outubro de $1995 . \quad$ Disponível http://stf.jus.br/portal/jurisprudencia/listarJurisprudencia.asp?s1=\%28MS\%24\%2ESCLA\%2E+E+
} 
"(...) A QUESTÃO DO DIREITO AO MEIO AMBIENTE ECOLOGICAMENTE EQUILIBRADO - DIREITO DE TERCEIRA GERAÇÃO - PRINCÍPIO DA SOLIDARIEDADE. - O direito à integridade do meio ambiente - típico direito de terceira geração - constitui prerrogativa jurídica de titularidade coletiva, refletindo, dentro do processo de afirmação dos direitos humanos, a expressão significativa de um poder atribuído, não ao indivíduo identificado em sua singularidade, mas, num sentido verdadeiramente mais abrangente, à própria coletividade social. Enquanto os direitos de primeira geração (direitos civis e políticos) - que compreendem as liberdades clássicas, negativas ou formais - realçam o princípio da liberdade e os direitos de segunda geração (direitos econômicos, sociais e culturais) - que se identificam com as liberdades positivas, reais ou concretas - acentuam o princípio da igualdade, os direitos de terceira geração, que materializam poderes de titularidade coletiva atribuídos genericamente a todas as formações sociais, consagram o princípio da solidariedade e constituem um momento importante no processo de desenvolvimento, expansão e reconhecimento dos direitos humanos, caracterizados, enquanto valores fundamentais indisponíveis, pela nota de uma essencial inexauribilidade. Considerações doutrinárias." (STF, Mandado de Segurança ${ }^{\circ}$ 22164, Rel. Min. Celso de Mello, Tribunal Pleno, Brasília (DF), 30 de outubro de 1995)

O direito fundamental ao saneamento básico, nesse panorama, é imprescindível para a fruição de diversos outros direitos humanos, sejam eles de primeira, segunda ou terceira geração. É, portanto, um serviço público essencial que compreende o abastecimento de água, esgotamento sanitário, limpeza e drenagem urbanas e coleta de lixo, cujo inadimplemento viola tanto direitos individuais como coletivos.

Além disso, cabe ressaltar que, de acordo com Rodolfo de Camargo Mancuso $^{37}$, o conceito de meio ambiente deve ser compreendido em todo seu alcance. Ou seja, não se atêm ao aspecto natural, como também inclui o âmbito cultural, artificial e do trabalho. ${ }^{38}$ São essas quatro formas que, conjuntamente equilibradas, constituem o direito ao meio ambiente ecologicamente equilibrado e possibilitam o desenvolvimento da vida. $\mathrm{O}$ autor ainda afirma não haver óbices de natureza jurídica à judicialização de

22164\%2ENUME\%2E\%29+OU+\%28MS\%2EACMS\%2E+ADJ2+22164\%2EACMS\%2E\%29\&b ase=baseAcordaos\&url=http://tinyurl.com/kpozytb. Acesso em: 01 de junho de 2018.

37 MANCUSO, Rodolfo de Camargo. Ação civil pública: em defesa do meio ambiente, do patrimônio cultural e dos consumidores (lei 7.347/85 e legislação complementar). 10a edição. São Paulo: Revista dos Tribunais, 2007. p. 37, 47.

${ }^{38}$ Essa noção a respeito do conceito de meio ambiente é mais abrangente do que a contemplada na Lei 6938/81 que, em seu artigo $3^{\circ}$, I dispõe, in verbis: Art. $3^{\circ}$ - Para os fins previstos nesta Lei, entende-se por: I - meio ambiente, o conjunto de condições, leis, influências e interações de ordem física, química e biológica, que permite, abriga e rege a vida em todas as suas formas. 
políticas públicas que demandam grandes e complexos empreendimentos, os quais podem gerar significativos efeitos sobre o meio ambiente. Entende-se, neste caso, não se tratar de ato administrativo discricionário apto a impedir intervenção do judiciário, pois impende a este Poder constituído assegurar a observância às normas e objetivos constitucionais. Não haveria, assim, violação, a priori, da separação dos poderes.

Em relação à responsabilidade civil por danos ambientais, em razão da própria natureza do direito, a mesma é objetiva, conforme depreende-se da conjugação do artigo $225, \S^{\circ}$ da CRFB/88 com os artigos $4^{\circ}$, inciso VII e $14, \S 1^{\circ}$, ambos da Lei $6935 / 81$, seja o réu particular ou o próprio Estado, vide art. $37 \S 6^{\circ}$ da $\mathrm{CRFB} / 88$. Especificamente nas questões ambientais, o principal objetivo é a recuperação ambiental, a recomposição, in natura, do status anterior aos danos e violações legais. ${ }^{39}$ Desse modo, o objetivo será sempre que possível a execução específica da obrigação. Isso significa que não se cogita substituir o dever de preservação ambiental por uma indenização em pecúnia. Um exemplo de responsabilização ocorre quando o Estado se omite, total ou parcialmente, a cumprir suas competências, como o exercício do poder de polícia ou a implementação de políticas públicas através da prestação adequada de um serviço público, cuja inexecução possa causar danos ambientais. É possível, inclusive, a configuração de dano moral coletivo, em decorrência da violação a valores coletivos que, com base na solidariedade, afeta a todos.

Sendo assim, considerando todas as características e aspectos explanados neste capítulo acerca do saneamento básico, será analisada a ação civil pública como meio adequado para a promoção da tutela judicial dos direitos e interesses envolvidos em torno dessa temática. ${ }^{40}$

\footnotetext{
39 MACHADO, Paulo Affonso Leme. Direito ambiental brasileiro. 22 edição. São Paulo: Malheiros, 2014. p. 418, 433-436.

${ }^{40}$ Como demonstrar-se-á adiante, um dos meios judiciais mais adequados para tutelar esses direitos e interesses é a ação civil pública que, através da exigência de prestação de adequado serviço público de saneamento básico assegura, por exemplo, o direito à saúde, dignidade humana, ao meio ambiente e ao mínimo existencial.
} 


\section{Capítulo 2. Ação Civil Pública e a Efetividade de Políticas Públicas para Acesso ao Sistema de Saneamento Básico}

\subsection{Processo Coletivo, Jurisdição e a Ação Civil Pública na Tutela de Direitos Difusos}

Antes de analisar aspectos processuais da tutela coletiva, especificamente da ação civil pública, é preciso discorrer sucintamente sobre o sentido do processo no Estado Democrático de Direito. Elege-se, nos artigos $1^{\circ}$ e $3^{\circ}$ da CRFB/88 os fundamentos e objetivos da República ${ }^{41}$. Já no artigo $5^{\circ}$, incisos XXXV, LIV e LV da Constituição Federal, prevê-se, respectivamente, a garantia do acesso à justiça, de inafastabilidade da jurisdição, o devido processo legal e, como consequência, o contraditório e a ampla defesa em processo judicial ou administrativo. $\mathrm{O}$ acesso à justiça deve ser não apenas formal, que significa o ingresso no poder judiciário, como também material. Ou seja, deve proporcionar uma prestação jurisdicional que satisfaça inteiramente às necessidades e demandas coletivas ou individuais, realizada num tempo razoável, a fim de garantir o resultado útil do processo, conforme dispõe o artigo $4^{\circ}$ do Código de Processo Civil.

Desse modo, promover-se-á a pacificação social e distribuição de justiça. O devido processo legal (e seus corolários), por sua vez, é um princípio que impõe a observância não apenas da legalidade estrita, mas do ordenamento jurídico e das normas constitucionais. Desse modo, o processo, embora possua sistematização própria, é compreendido como instrumento de concretização do direito material. Quanto a este ponto vale destacar o artigo $8^{\circ}$ da Lei 13105/2015:

“Art. $8^{\circ}$ Ao aplicar o ordenamento jurídico, o juiz atenderá aos fins sociais e às exigências do bem comum, resguardando e promovendo a dignidade da pessoa

\footnotetext{
${ }^{41}$ Em virtude do escopo do trabalho, destacam-se a dignidade da pessoa humana, a construção de uma sociedade livre, justa e solidária, a garantia do desenvolvimento nacional, erradicação da pobreza, da marginalização e redução das desigualdades sociais e regionais.
} 
humana e observando a proporcionalidade, a razoabilidade, a legalidade, a publicidade e a eficiência."

De acordo com Marcelo Abelha Rodrigues ${ }^{42}$, o processo, seja ele judicial, legislativo ou administrativo, deve ser concebido como meio de "concretização de direitos fundamentais" através do qual os poderes constituídos do Estado, democraticamente, atuam. Assim, através de um devido processo democrático, balizado pela adequação, justiça e os demais princípios processuais, haverá, de fato, acesso à justiça. A tutela justa, nesse sentido, ocorre quando se atinge, da maneira mais aproximada possível, a compatibilidade entre o direito material da parte com o resultado da demanda. Destaca-se, então, o seguinte ensinamento de Marcelo Abelha Rodrigues:

\begin{abstract}
"Portanto, o processo nada mais é do que um método de trabalho estatal, que deve pautar o exercício das funções judiciária, executiva e legislativa. O Estado democrático de Direito exige que este método de trabalho seja um espelho do que se espera de uma democracia, ou seja, o processo estatal (administrativo, jurisdicional ou legislativo) deve refletir os cânones democráticos, o que significa dizer que deve ser participativo, impessoal, transparente, fundamentado, com amplo contraditório e defesa, célere, entre outras características que garantam e realizem o que se denomina de direito fundamental ao devido processo. Cingindose ao processo jurisdicional, este método de trabalho tem por finalidade resolver conflitos e pacificar as lides, aí incluída a atividade jurisdicional satisfativa, devendo restar claro que existe um compromisso do método com o resultado para o qual ele existe e serve de instrumento. É, portanto, imperativo constitucional, tanto sob o ponto de vista do dever do Estado Democrático, quanto sob o prisma do direito fundamental do cidadão, que tal processo (método) realize e reflita o devido processo legal; este postulado que é uma cláusula aberta cujo núcleo formativo é a duração razoável, a isonomia, o contraditório e ampla defesa, o dever de fundamentação das decisões judiciais, a imparcialidade, o juiz e promotor natural. O devido processo legal impõe o modo de ser do processo, fazendo com que não seja simplesmente um método qualquer de atuação do estado (judiciário, administrativo e legislativo), mas sim um método democrático de atuação do estado, tal como impõe o texto constitucional. Deve o processo ser um método (ele mesmo um direito fundamental) que realiza os direitos fundamentais materiais individuais e coletivos, respeitando as características e singularidades desses direitos, sob pena de ser um instrumento inútil e descomprometido como o seu fim." 43
\end{abstract}

\footnotetext{
${ }^{42}$ RODRIGUES, Marcelo Abelha. Processo Civil Ambiental. $4^{\mathrm{a}}$ edição. São Paulo: JusPODIVM, 2016.p.92-93

${ }^{43}$ Ibid. p.99.
} 
Nesse sentido, o processo coletivo, especificamente a ação civil pública na tutela de direitos difusos, consagra os pressupostos do Estado Democrático de Direito insertos na Constituição da República Federativa do Brasil de 1988. Afirma-se isso porque a referida ação consiste em eficaz instrumento processual para efetivação de direitos fundamentais e possibilita, através dos legitimados para sua propositura, a participação de diversos atores sociais para defender interesses de titularidade indeterminada e objeto indivisível em juízo. Conforme lecionam Fredie Didier Jr. e Hermes Zaneti $\mathrm{Jr}$ :

\begin{abstract}
"O processo é coletivo se a relação jurídica litigiosa (a que é objeto do processo) é coletiva. uma relação jurídica é coletiva se em um de seus termos, como sujeito ativo ou passivo, encontra-se um grupo (comunidade, categoria, classe, etc.; designa-se qualquer um deles pelo gênero grupo) e, se no outro termo, a relação jurídica litigiosa envolver direito (situação jurídica ativa) ou dever ou estado de sujeição (situações jurídicas passivas) de um determinado grupo. Assim, presentes o grupo e a situação jurídica coletiva, está-se diante de um processo coletivo."

(...)

"O processo coletivo brasileiro, por exemplo, tem suas próprias características variáveis, pois decorrentes de regras jurídicas que podem ser alteradas. essas características compõem o devido processo legal coletivo brasileiro; compõem, enfim, o perfil dogmático do processo coletivo no Brasil. São elas: a) a legitimação para agir, normalmente atribuída a um legitimado extraordinário ope legis; b) o regime da coisa julgada coletiva, que permite a extensão in utilibus para as situações jurídicas individuais; c) a caracterização da litigação de interesse público, que é requisito para o prosseguimento de um processo coletivo, flexibiliza o procedimento a favor da tutela de mérito e determina a intervenção obrigatória do Ministério Público como fiscal do ordenamento jurídico e todas as ações. Todas são características contingenciais do processo coletivo brasileiro - não compõem, porém, o conceito de processo coletivo." 44
\end{abstract}

Sendo assim, observados o conceito e características do processo coletivo, a ação civil pública insere-se como o instrumento hábil para tutelar direitos transindividuais e garantir sua observância pelos agentes públicos e sociais. Essa característica da ação civil pública é de extrema relevância para a ordem jurídica, pois quando, em razão da natureza do direito, não é possível obter-se um provimento jurisdicional através de demanda individual, é na ação coletiva que se possibilita, à sociedade civil, através da legitimação das

${ }^{44}$ DIDIER Jr, Fredie, ZANETI Jr, Hermes. Curso de Direito Processual Civil: Processo Coletivo. $12^{\mathrm{a}}$ edição, volume 4. Salvador, BA: JusPODIVM, 2018. p. 31, 33-34. 
associações, e aos órgãos integrantes do Estado legitimados, a materialização dos interesses da coletividade ${ }^{45}$, sobre os quais orbitam legítimas expectativas de eficácia social das disposições insertas na Constituição Federal. Ou seja, o processo coletivo emerge como componente basilar do Estado Democrático de Direito ao permitir a tutela de direitos tão caros à sociedade, como o meio ambiente, ordem econômica, patrimônio público e social.

\subsubsection{Princípios do Processo Coletivo}

Inicialmente cabe ressaltar que os princípios são importantes para aplicação e interpretação do ordenamento jurídico. Dentre os princípios da tutela coletiva destacam-se os seguintes: representatividade adequada, prevalência do conhecimento de mérito, atipicidade das ações coletivas, não taxatividade, indisponibilidade temperada da demanda, continuidade das ações coletivas, ampla publicidade, reparação integral do dano, tutela específica, boa-fé e cooperação processual. ${ }^{46} \mathrm{O}$ princípio da representatividade adequada ${ }^{47}$ trata da necessidade de o autor possuir as condições materiais e recursos necessários para atuar no processo coletivo, em que há múltiplos interesses de amplo alcance social.

Já o princípio da prevalência do conhecimento de mérito ${ }^{48}$ prima pela instrumentalidade das formas, conferindo maior flexibilidade procedimental para que se julgue o mérito do processo. Assim, é possível sanar vícios formais, como legitimidade, vez que o objetivo primordial do processo é solucionar o litígio, tutelar o direito material. Então, não se extingue o processo sem que se confira a substituição processual pelo Ministério

\footnotetext{
${ }^{45}$ É preciso notar que o interesses público, coletivo e privado muitas vezes são convergentes e, não se vislumbra, indiscriminadamente, atribuir uma absoluta relação de contraposição entre eles. Desse modo, o atendimento ao interesse coletivo - especificamente no caso do saneamento básico também pode repercutir na satisfação de interesses privados.

${ }^{46}$ Ibid. p. 97-104.

${ }^{47}$ DIDIER Jr, Fredie, ZANETI Jr, Hermes. Curso de Direito Processual Civil: Processo Coletivo. $12^{\mathrm{a}}$ edição, volume 4. Salvador, BA: JusPODIVM, 2018. p. 110.

${ }^{48}$ DONIZETTI, Elpídio; CERQUEIRA, Marcelo Malheiros. Curso de Processo Coletivo: Contém Jurisprudência Temática e Índice Alfabético de Assuntos. $1^{a}$ ed. São Paulo: Atlas, 2010. p. 94.
} 
Público, ou abertura de edital para que alguma associação assuma o polo ativo, por exemplo.

Além desses, há o princípio da atipicidade, das ações coletivas ${ }^{49}$, previsto no artigo 83 do Código de Defesa do Consumidor, que significa o cabimento de quaisquer meios processuais válidos para tutelar os bens jurídicos em questão, bem como o uso de medidas preventivas ou repressivas para sua satisfação. Esse princípio, também denominado como da não taxatividade, encontra-se insculpido no artigo $1^{\circ}$, inciso V da Lei $7347 / 85$ (cláusula geral de atipicidade), permitindo a tutela de qualquer outro interesse difuso ou coletivo, não previsto no rol do referido dispositivo. Ou seja, são incluídos aspectos de direito material para proteger qualquer direito transindividual.

Há, também, o princípio da indisponibilidade temperada da demanda ${ }^{50}$. Esse princípio prevê que, em razão da natureza extraordinária da legitimidade ativa da ação civil pública, ao constatar fatos que coloquem em risco direitos transindividuais indisponíveis, o Ministério Público terá o dever de propor a ação coletiva. Ou seja, havendo o interesse social, o autor não pode dispor da demanda.

Esse poder-dever também se aplica à Defensoria Pública e à Advocacia Pública, quando de suas atuações em processos coletivos, pois o Ministério Público não é o único detentor do interesse público. Ressalta-se, também, o princípio da continuidade das ações coletivas ${ }^{51}$. Segundo este, a depender da causa em questão, o Ministério Público deve assumir o polo ativo em caso de abandono ou desistência da ação pelo autor. Outro princípio relevante é o da ampla publicidade ${ }^{52}$, que visa permitir o controle e

\footnotetext{
${ }^{49}$ MAZZILLI, Hugo Nigro. A defesa dos interesses difusos em juízo: meio ambiente, consumidor, patrimônio cultural, patrimônio público e outros interesses. 30. ed. São Paulo: Saraiva, 2017. p. 100.

${ }^{50}$ DIDIER Jr, Fredie, ZANETI Jr, Hermes. Curso de Direito Processual Civil: Processo Coletivo. $12^{\mathrm{a}}$ edição, volume 4. Salvador, BA: JusPODIVM, 2018. p. 121-124.

${ }^{51}$ DONIZETTI, Elpídio; CERQUEIRA, Marcelo Malheiros. Curso de Processo Coletivo: Contém Jurisprudência Temática e Índice Alfabético de Assuntos. $1^{a}$ ed. São Paulo: Atlas, 2010. p. 107-110. ${ }^{52}$ DIDIER Jr, Fredie, ZANETI Jr, Hermes. Curso de Direito Processual Civil: Processo Coletivo. $12^{\mathrm{a}}$ edição, volume 4. Salvador, BA: JusPODIVM, 2018. p. 113-115.
} 
participação social, a ciência dos interessados para adoção das medidas cabíveis, evidenciar a lisura do procedimento e permitir o amplo alcance social dos efeitos da decisão.

Por sua vez, o princípio da reparação integral do dano, conforme $\operatorname{artigos} 1^{\circ}, 3^{\circ}$ e 11 da Lei 7347/85, determina a possibilidade de cumulação de pedidos, de obrigações de fazer, não fazer e indenizar. Essa hipótese coaduna-se com busca pela tutela específica, pois o objetivo é tutelar o bem jurídico em espécie, ou seja, uma obrigação de natureza diversa não pode substituir a responsabilidade do réu de reparar o direito ou interesse transindividual naquilo em que este foi violado. Por exemplo, no caso de danos ambientais é essencial, para restaurar o status quo ante, não só a reparação in natura do dano, como também em toda a sua extensão, patrimonial e extrapatrimonial, inclusive danos futuros e reflexos.

Há, ainda, os princípios da boa-fé e cooperação processual ${ }^{53}$ entre as partes do processo, vide artigos $5^{\circ}$ e $6^{\circ}$ do código de processo civil. Tais princípios foram, inclusive, inseridos no projeto de lei que pretende reformar a Lei 7347/85. Esses postulados impõem, às partes, o cumprimento de deveres processuais, como agir com lealdade e não atuar de modo a procrastinar o processo, conforme art. 77 do código de processo civil. A não observância desses princípios pode acarretar na decretação de litigância de má-fé e, como principal consequência, na sujeição da parte em suportar as custas processuais majoradas, conforme determinam os artigos 17 e 18 da Lei $7347 / 85$.

Por fim, destaca-se o princípio do microssistema de processo coletivo $^{54}$, o qual pressupõe a coexistência de leis que visam atender às peculiaridades das demandas coletivas, que possuem regras e valores específicos cuja aplicação é sistemática. O microssistema de tutela coletiva possui coerência própria, engloba e impõe, ao intérprete do direito, a

\footnotetext{
${ }^{53}$ DONIZETTI, Elpídio; CERQUEIRA, Marcelo Malheiros. Curso de Processo Coletivo: Contém Jurisprudência Temática e Índice Alfabético de Assuntos. $1^{a}$ ed. São Paulo: Atlas, 2010. p. 88.

${ }^{54}$ DIDIER Jr, Fredie, ZANETI Jr, Hermes. Curso de Direito Processual Civil: Processo Coletivo. $12^{\mathrm{a}}$ edição, volume 4. Salvador, BA: JusPODIVM, 2018. p. 124-126.
} 
integração e complementação normativa de diversos diplomas legais, tais como: Lei 4.717/65 (Ação Popular), Lei 7.347/85 (Ação Civil Pública), Lei 8.078/1990 (CDC), Lei 8.429/92 (Defesa da Probidade), Lei 12.016/09 (Mandado de Segurança Coletivo), Lei 12.529/11 (Defesa da Concorrência), Lei 8.069/90 (ECA), Lei 10.741/2003 (Estatuto do Idoso) e Lei 12.527/2012 (Acesso à informação). Desse modo, o Código de Processo Civil aplica-se subsidiariamente, no que for compatível com os preceitos do processo coletivo.

\subsection{Ação Civil Pública e Direitos Difusos}

O processo coletivo surge ante a necessidade de resposta jurisdicional adequada à novas demandas da sociedade, não mais comportadas pela lógica processual tradicional de tutela de direitos subjetivos e individuais ${ }^{55}$. São interesses que, pela sua natureza, não podem ser reivindicados individualmente. Em uma sociedade que é cada vez mais plural, dinâmica, e tecnológica, é comum a ocorrência de conflitos complexos, que atingem um número amplo e indeterminado de pessoas, como no caso do direito ao meio ambiente e dos mais diversos direitos sociais. Trata-se de direitos transindividuais, em sua maioria fundamentais e indisponíveis, de titularidade indeterminada. Assim, impõe-se ao Direito apresentar institutos e ferramentas que, de fato, confiram efetividade a esses direitos.

As ações coletivas, nesse cenário, permitem a participação social através da ação dos substitutos processuais, que postulam em juízo os interesses da coletividade com objetivo, por exemplo, de controlar, rever e adequar atos administrativos e políticas públicas que não se coadunam com a ordem jurídica. Tem-se, assim, o acesso à justiça e a democratização do processo, que é notadamente de interesse público, ao dispensar-se um

\footnotetext{
55 MANCUSO, Rodolfo de Camargo. Ação civil pública: em defesa do meio ambiente, do patrimônio cultural e dos consumidores (lei 7.347/85 e legislação complementar). 10 ${ }^{a}$ edição. São Paulo: Revista dos Tribunais, 2007. p. 52-54.
} 
tratamento adequado aos conflitos nos quais haja a presença de direitos difusos.

Vale ainda destacar que a legislação sobre a tutela coletiva de direitos não é uniformizada em um código, de modo que se reconhece a existência de diversas leis esparsas que dialogam entre si, complementam-se e constituem um microssistema legal ${ }^{56}$. O objeto da tutela coletiva é composto, precipuamente, por direitos humanos de $3^{\mathrm{a}}$ geração, direitos de solidariedade, difusos, mas também abarcam os de $2^{\mathrm{a}}$ geração, direitos de igualdade, sociais, e $1^{a}$ geração, direitos de liberdade, individuais. Especificamente quanto a ação civil pública, o objeto, os legitimados e a coisa julgada constituem-se como características marcantes dessa ação coletiva. Elementos que serão abordados, pontualmente, em tópico próprio a seguir.

A ação civil pública, prevista no artigo 129, III da CRFB/88 e regulamentada na lei 7347/1985, é uma espécie de ação de natureza coletiva que possui como objeto direitos transindividuais e um rito especial destinado à sua tutela específica. ${ }^{57}$ Por meio da atuação da sociedade civil no processo judicial, seja pelas associações, como administração pública ou representação do Ministério Público e Defensoria Pública, a ação civil pública cinge-se como ferramenta de defesa social, da cidadania. Ou seja, o Poder Judiciário é instado a agir e proferir decisão com alcance erga omnes, de largo espectro e cuja finalidade é eficácia jurídica e social de direitos previstos no ordenamento jurídico. Possibilita-se, inclusive, recorrer-se ao Judiciário, em certos casos, para adoção de medidas que concretizem as determinações firmadas pela legislação referentes às bases de políticas públicas voltadas para os direitos sociais. ${ }^{58}$

\footnotetext{
${ }^{56}$ DIDIER Jr, Fredie, ZANETI Jr, Hermes. Curso de Direito Processual Civil: Processo Coletivo. $12^{\mathrm{a}}$ edição, volume 4. Salvador, BA: JusPODIVM, 2018. p. 124.

${ }^{57}$ CARVALHO FILHO, José dos Santos. Manual de direito administrativo. $27^{\mathrm{a}}$ edição. São Paulo: Atlas, 2014. p.1082.

${ }^{58}$ MAZZILLI, Hugo Nigro. A defesa dos interesses difusos em juízo: meio ambiente, consumidor, patrimônio cultural, patrimônio público e outros interesses. 30. ed. São Paulo: Saraiva, 2017. p. $187-189$
} 
Rodolfo de Camargo Mancuso ${ }^{59}$, afirma que a natureza pública dessa ação civil decorre justamente de seu objeto, da pretensão material objetivada, sobre a qual se inserem "um largo espectro de interesses e valores de inegável relevância social", inclusive direitos e garantias fundamentais constitucionalmente consagrados. ${ }^{60}$ São conflitos transindividuais que necessitam de tutela processual própria para que se garanta o acesso à justiça formal e material, ou seja o ingresso no poder judiciário e a efetiva prestação jurisdicional.

A ação civil pública é, portanto, um instrumento processual cujo objetivo é garantir interesses e direitos transindividuais, incluídos os difusos, coletivos e individuais homogêneos, vide art. 81 do Código de Defesa do Consumidor. ${ }^{61}$ Conforme evidencia a cláusula genérica do art. $1^{\circ}$, IV da Lei 7347/85, seu objeto é amplo e engloba todas as espécies de direitos transindividuais. ${ }^{62}$ Nesse sentido, destacam-se os conceitos previstos no artigo 81, parágrafo único, incisos I, II e III da Lei n 8078/1990. No caso dos direitos difusos, o objeto é indivisível, ou seja, não pode ser apreendido individualmente de forma exclusiva, mas por toda a sociedade atingida, havendo uma titularidade indeterminada.

Assim, consequentemente, a satisfação que leva à reparação da lesão aos direitos de um titular produz efeitos para todos uniformemente e instantaneamente. Além disso, os titulares de interesses ou direitos difusos são indeterminados e vinculados por uma situação fática temporária e mutável, não há entre eles uma relação jurídica base. Especialmente nesses

\footnotetext{
${ }^{99}$ MANCUSO, Rodolfo de Camargo. Ação civil pública: em defesa do meio ambiente, do patrimônio cultural e dos consumidores (lei 7.347/85 e legislação complementar). $10^{a}$ edição. São Paulo: Revista dos Tribunais, 2007. p.22.

${ }^{60}$ É reconhecida a amplitude do objeto da ação civil pública, seja pelo artigo $1^{\circ}$, IV da lei $7347 / 85$, como pelo artigo 129, III CRFB/88 e do art. 37 da CRFB/88 conjugado com o artigo art. 22 do CDC. ${ }^{61}$ Também denominados supraindividuais, metaindividuais ou coletivos lato sensu. Neste capítulo o enfoque dar-se-á nos aspectos gerais da tutela coletiva e da ação civil pública envolvendo direitos difusos, tema do presente trabalho, através do direito difuso ao saneamento básico. Conforme já explicitado, o objetivo do presente trabalho monográfico não é adentrar amiúde nos aspectos processuais, nem tampouco nas controvérsias doutrinárias e jurisprudenciais de seus institutos.

${ }^{62}$ Sobre as espécies de direitos transindividuais: MAZZILLI, Hugo Nigro. A defesa dos interesses difusos em juízo: meio ambiente, consumidor, patrimônio cultural, patrimônio público e outros interesses. 30. ed. São Paulo: Saraiva, 2017. p. 52-60.
} 
direitos há maior conflituosidade e disputa política, pois há incidência de interesses diversos, muitas vezes diametralmente opostos ${ }^{63}$.

O objeto da ação civil pública abrange, como depreende-se do artigo $1^{\circ}$ da Lei 7347/85, a proteção ao meio ambiente, ao consumidor, ao patrimônio público, social e cultural ${ }^{64}$, à ordem econômica, urbanística, à honra e dignidade de grupos étnicos, raciais ou religiosos, bem como a quaisquer outros interesses difusos, coletivos e individuais homogêneos. Desse modo, possibilita, dentre outras coisas, o controle judicial de atos administrativos e de políticas públicas, a tutela do interesse público primário $^{65}$, de minorias, hipossuficientes e vulneráveis, de valores constitucionais. São questões de ordem pública e social.

\subsection{Ação Civil Pública: Disposições Gerais e Aspectos Processuais}

A legitimidade ativa na ação civil pública é de natureza extraordinária, pois o autor atua em nome próprio, sobre direitos materiais que não são seus ou exclusivamente seus, é um caso de substituição processual. ${ }^{66}$ Os legitimados são identificados pela legislação como representantes adequados e substituem-se à coletividade, por isso é extraordinária a legitimação. Essa legitimidade ativa é plúrima, concorrente-disjuntiva ${ }^{67}$, como observa-se no rol do artigo $5^{\circ}$ da Lei $7347 / 85$ e no art. $129 \S 1^{\circ}$ da CRFB/88, o qual dispõe que a legitimação do Ministério Público para a ação civil pública não impede a de terceiros. Os legitimados concorrem entre si para propor a ação e não dependem para tal, da intervenção ou concordância dos demais, ou seja, a atuação de cada um é autônoma em relação ao outro. Deve, ainda, haver a

\footnotetext{
${ }^{63}$ DIDIER Jr, Fredie, ZANETI Jr, Hermes. Curso de Direito Processual Civil: Processo Coletivo. $12^{\mathrm{a}}$ edição, volume 4. Salvador, BA: JusPODIVM, 2018. p. 76.

${ }^{64}$ Conforme dispõem os artigos 129, III e 215 e 216 da CRFB/88.

${ }^{65} \mathrm{Na}$ ação civil pública há a presença do interesse público primário, complexo de interesses que prevalecem na sociedade. Objetiva-se a proteção e concretização de valores e objetivos constitucionais, inclusive através do controle de políticas públicas.

${ }^{66}$ DIDIER Jr, Fredie, ZANETI Jr, Hermes. Curso de Direito Processual Civil: Processo Coletivo. $12^{\mathrm{a}}$ edição, volume 4. Salvador, BA: JusPODIVM, 2018. p. 199.

${ }^{67}$ MANCUSO, Rodolfo de Camargo. Ação civil pública: em defesa do meio ambiente, do patrimônio cultural e dos consumidores (lei 7.347/85 e legislação complementar). $10^{\mathrm{a}}$ edição. São Paulo: Revista dos Tribunais, 2007. p. 107. Op. Cit. p. 417-419.
} 
representação adequada, pois os legitimados ativos atuam representando direitos alheios e, assim, devem possuir recursos e condições técnicas e materiais para tal. Os legitimados, no artigo $5^{\circ}$, são o Ministério Público, Defensoria Pública, Administração Pública Direta e Indireta e Associação Civil constituída há mais de um ano e com a presença da finalidade institucional de defesa de direitos transindividuais.

O Ministério Público tem atuação com fundamento constitucional na propositura de ações civis públicas. Sua legitimidade decorre do art. 129, III da CRFB/88, que determina como sua função institucional "promover $o$ inquérito civil e a ação civil pública, para a proteção do patrimônio público e social, do meio ambiente e de outros interesses difusos e coletivos", bem como do art. $5^{\circ}$, I da Lei 7347/85. Em relação ao inquérito civil, trata-se de procedimento administrativo cuja realização é facultada ao Ministério Público, conforme art. $8^{\circ}, \S 1^{\circ}$ e art. $9^{\circ}$ da Lei $7347 / 85$, através do qual se pretende apurar os fatos para adoção das medidas cabíveis, quais sejam, o arquivamento do caso, realização de compromisso de ajustamento de conduta com a parte potencial causadora do dano, ou propositura da ação civil pública.

Conforme determina o artigo 127 da CRFB/88, incumbe ao Ministério Público, enquanto instituição permanente e essencial à jurisdição estatal, " $a$ defesa da ordem jurídica, do regime democrático e dos interesses sociais e individuais indisponíveis". São, justamente, bens jurídicos como direitos indisponíveis e o interesse social aqueles tutelados via ação civil pública. Vale ainda destacar a Lei Complementar $n^{\circ} 75 / 93$, que dispõe sobre a organização e atribuições do Ministério Público da União Federal. Destacase, no referido diploma legal, o art. $6^{\circ}$, VII, onde há previsão para o Parquet promover a ação civil pública, e o artigo $5^{\circ}$, o qual elenca como funções institucionais uma ampla série de direitos e interesses tutelados pelo Ministério Público, como o patrimônio público e social, o meio ambiente, direitos e interesses coletivos, lato sensu. $\mathrm{O}$ artigo $5^{\circ}$, ainda, no inciso $\mathrm{V}$, alíneas a e b dispõe, in verbis: 
“Art. $5^{\circ}$ São funções institucionais do Ministério Público da União:

(...)

V - Zelar pelo efetivo respeito dos Poderes Públicos da União e dos serviços de relevância pública quanto:

a) aos direitos assegurados na Constituição Federal relativos às ações e aos serviços de saúde e à educação;

b) aos princípios da legalidade, da impessoalidade, da moralidade e da publicidade;"

Nesse sentido, o art. 11 da Lei Complementar $n^{\circ} 75 / 93$, ao dispor que "a defesa dos direitos constitucionais do cidadão visa à garantia do seu efetivo respeito pelos Poderes Públicos e pelos prestadores de serviços de relevância pública”, fundamenta a atenção dada na esfera da proteção do patrimônio público. Ressalta-se também, a Lei 8625/93, que no art.25, IV prevê a atribuição do Ministério Público para promover a ação civil pública e, no art. 27, dispõe, in verbis que:

"Art. 27. Cabe ao Ministério Público exercer a defesa dos direitos assegurados nas Constituições Federal e Estadual, sempre que se cuidar de garantir-lhe o respeito: I - pelos poderes estaduais ou municipais;

II - pelos órgãos da Administração Pública Estadual ou Municipal, direta ou indireta;

III - pelos concessionários e permissionários de serviço público estadual ou municipal;

IV - por entidades que exerçam outra função delegada do Estado ou do Município ou executem serviço de relevância pública."

De acordo com o entendimento de Rodolfo de Camargo Mancuso ${ }^{68}$, a atuação do Ministério Público através de ação civil pública corresponde às suas funções institucionais, como se observa na lei 8625/93, artigo 25, IV e artigos 127 e 129, III da CRFB/88. Desse modo, depreende-se que o interesse de agir do Parquet é legalmente presumido, ou seja, presentes o trinômio necessidade, utilidade e adequação (analisados casuisticamente), o interesse

\footnotetext{
${ }^{68}$ MANCUSO, Rodolfo de Camargo. Ação civil pública: em defesa do meio ambiente, do patrimônio cultural e dos consumidores (lei 7.347/85 e legislação complementar). $10^{a}$ edição. São Paulo: Revista dos Tribunais, 2007. p. 53-54
} 
público, direitos e interesses coletivos indisponíveis, estará ele apto a promover a ação civil pública, sem mais requisitos. ${ }^{69}$

Além disso, no artigo $5^{\circ}$ Lei $7347 / 85$, parágrafos $1^{\circ}$ à $6^{\circ}$, determinase que não sendo o Ministério Público o autor da ação, o mesmo obrigatoriamente intervirá no processo como custos legis, sob pena de nulidade do feito. Havendo desistência ou abandono da ação pelo autor, o mesmo tem o poder dever de assumir o polo ativo, caso verifique-se a pertinência social. Podem, ainda, o Ministério Público ou órgãos da Administração Pública realizar o compromisso de ajustamento de conduta com o interessado. Por fim, faculta-se a instituição de litisconsórcio ativo entre os Ministérios Públicos dos Estados, do Distrito Federal e da União. Vale ressaltar que o Ministério Público, conforme artigos $6^{\circ}$, XV e $8^{\circ}$, I a VIII da lei complementar 75/93, pode manifestar-se em qualquer fase do processo.

A Defensoria Pública, por sua vez, é legitimada ativa para propositura da ação civil pública como previsto no inciso II do artigo $5^{\circ}$ da Lei 7347/85. Assim como o Ministério Público, seu interesse de agir é presumido por lei. Sua atuação ocorre à luz do artigo 134 da CRFB/88, no qual essa instituição é referida como permanente e indispensável ao regime democrático e à jurisdição estatal. Conforme determina o referido dispositivo, atribui-se a ela, precipuamente, as funções de "orientação jurídica, promoção dos direitos humanos e a defesa, em todos os graus, judicial e extrajudicial, dos direitos individuais e coletivos, de forma integral e gratuita, aos necessitados, na forma do inciso LXXIV do art. $5^{\circ}$ da CRFB/88." Nota-se, portanto, que a Constituição expressamente prevê sua atuação na defesa de direitos coletivos.

Desse modo, cabe destacar que o artigo $5^{\circ}$, LXXIV da CRFB/88 estabelece que "o Estado prestará assistência jurídica integral e gratuita aos que comprovarem insuficiência de recursos". Portanto, combinando o teor

\footnotetext{
${ }^{69}$ Sobre a atuação do Ministério Público na ação civil pública: MAZZILLI, Hugo Nigro. A defesa dos interesses difusos em juízo: meio ambiente, consumidor, patrimônio cultural, patrimônio público e outros interesses. 30. ed. São Paulo: Saraiva, 2017. p. 94-110, 409-417.
} 
do art. $5^{\circ}$, LXXIV com o disposto no art. 134 da CRFB/88, a função institucional da Defensoria Pública consiste na defesa e assistência jurídica dos necessitados. Assim, para constatar-se a legitimatio ad causam da Defensoria Pública na ação civil pública, haverá, como regra, a presença do interesse dos necessitados ${ }^{70}$, como por exemplo, grupos vulneráveis, hipossuficientes e minoritários. Ressalta-se que, havendo a presença de hipossuficientes, a Defensoria Pública possui legitimidade para atuar na defesa de direitos transindividuais mesmo quando também houver titulares economicamente suficientes, em razão da indivisibilidade do objeto da ação e do interesse público subjacente à causa.

Quanto a legitimidade da Defensoria Pública há, por fim, a Lei Complementar $\mathrm{n}^{\circ} 80$ de 1994, com as alterações introduzidas pela Lei Complementar $n^{\circ} 132 / 2009$. O referido diploma legal, reproduz no art. $1^{\circ} \mathrm{o}$ disposto no art. 134 da CRFB/88. Além disso, em seu artigo $4^{\circ}$, inciso VII dispõe como função institucional da Defensoria Pública, in verbis, "promover ação civil pública e todas as espécies de ações capazes de propiciar a adequada tutela dos direitos difusos, (...) quando o resultado da demanda puder beneficiar grupo de pessoas hipossuficientes."

Importante, ainda, quanto aos demais legitimados, destacar a presença das associações civis, com legitimidade inserta no inciso $\mathrm{V}$, alíneas a e b do artigo $5^{\circ}$ da Lei $7347 / 85$. Ressalta-se que as mesmas devem cumprir dois requisitos para constatar-se sua legitimidade. Quais sejam, estarem constituídas há, no mínimo, 1 (um) ano segundo os termos da lei civil ${ }^{71}$ e também haver a pertinência temática, aferida quando a associação possui, entre suas finalidades institucionais, previstas no estatuto ou contrato social, a defesa de algum bem jurídico objeto no rol do artigo $1^{\circ}$ da Lei $7347 / 85$, que se pretende tutelar via ação civil pública. ${ }^{72}$

\footnotetext{
${ }^{70}$ CARVALHO FILHO, José dos Santos. Manual de direito administrativo. $27^{\mathrm{a}}$ edição. São Paulo: Atlas, 2014. p.1086-1087.

${ }^{71}$ Conforme dispõem os artigos 45 e 46 do Código Civil de 2002 e artigos 114 a 121 da lei 6015/73.

${ }^{72}$ MAZZILLI, Hugo Nigro. A defesa dos interesses difusos em juízo: meio ambiente, consumidor, patrimônio cultural, patrimônio público e outros interesses. 30. ed. São Paulo: Saraiva, 2017. p. $395-408$
} 
Também é preciso dispensar atenção à legitimidade dos entes federativos e de órgãos da Administração Pública direta e indireta que está, respectivamente, presente nos incisos III e IV do artigo $5^{\circ}$ da Lei 7347/85.

Já em relação à legitimidade passiva, de acordo com José dos Santos Carvalho Filho:

"No polo passivo, não há qualquer especificidade. Quem quer que se conduza de forma ofensiva a tais interesses, seja pessoa física ou jurídica, pública ou privada, será o demandado na ação civil pública. A legitimação passiva, por conseguinte, é daquele cuja conduta vulnerar os interesses sob tutela." 73

É possível, por exemplo, haver litisconsórcio passivo entre a Administração Pública e os possíveis causadores de lesão aos direitos transindividuais. É preciso notar que a amplitude do polo passivo na ação civil pública decorre da natureza indisponível dos bens jurídicos veiculados, os quais demandam reparação integral e tutela específica. Para isso, portanto, é essencial incluir todos aqueles que concorreram para o dano.

\subsubsection{Competência na Ação Civil Pública}

A competência para o processamento da ação civil pública decorre da conjugação do artigo $2^{\circ}$ da Lei 7347/85 com o artigo 93 do Código de Defesa do Consumidor. ${ }^{74}$ Em regra, determina-se a competência jurisdicional pelo local do dano, mas deve-se observar a competência absoluta da Justiça Federal, conforme art. 109, I da CRFB/88, nos casos de danos afetos à União Federal, suas autarquias ou empresas públicas.

Sendo de âmbito local, aplica-se o artigo $2^{\circ}$ da Lei $7347 / 85$. No caso de danos de âmbito regional ou nacional, a competência será do foro da capital do Estado ou do Distrito Federal. Assim, usualmente, a competência

\footnotetext{
${ }^{73}$ CARVALHO FILHO, José dos Santos. Manual de direito administrativo. $27^{\text {a }}$ edição. São Paulo: Atlas, 2014. p. 1087.

${ }^{74}$ MAZZILLI, Hugo Nigro. A defesa dos interesses difusos em juízo: meio ambiente, consumidor, patrimônio cultural, patrimônio público e outros interesses. 30. ed. São Paulo: Saraiva, 2017. p. 337-340, 349-356.
} 
será do juízo de primeira instância do local do dano. Será processada na justiça comum estadual, hipótese que se configura no caso do saneamento básico, geralmente. Contudo, se a União ou uma autarquia federal for parte, a Justiça Federal será competente. Ressalta-se, ainda, que se aplica subsidiariamente as regras do Código de Processo Civil para casos de conflitos de competência.

\subsection{Sentença e Efeitos da Decisão na Ação Civil Pública que Tutela Direitos Difusos}

Como regra geral, a sentença na ação civil pública tem caráter condenatório e cominatório, ou seja, há possibilidade de cumulação das obrigações previstas no artigo $3^{\circ}$ cujo objetivo é proporcionar a tutela específica ao bem jurídico objeto da demanda coletiva, vide artigo 11 da Lei 7347/85. Além disso, a decisão pode assumir natureza repressiva ou preventiva. ${ }^{75}$ No primeiro caso, impõe-se uma obrigação de não fazer e de reparar o dano (obrigações de fazer e indenizar), como no caso de decisões mandamentais que versam sobre políticas públicas. Já na segunda hipótese, pretende-se evitar a ocorrência do dano. Ressalta-se que a ação civil pública também pode ter natureza declaratória, quando reconhece a existência de algum direito. Quanto a natureza da sentença vale destacar o ensinamento de Jose dos Santos Carvalho Filho:

"A sentença, na ação civil pública, dependerá da natureza do pedido formulado na
ação, que pode variar conforme o caso. Dita o art. $3^{\circ}$ da Lei no $7.347 / 1985$ que "a
ação civil poderá ter por objeto a condenação em dinheiro ou o cumprimento de
obrigação de fazer ou não fazer". No primeiro caso, se procedente a ação, a
sentença terá conteúdo condenatório pecuniário, já que o réu será condenado a
pagar em dinheiro a indenização pelos danos causados por sua conduta ofensiva.
No segundo, a sentença terá natureza condenatória mandamental (ou simplesmente
mandamental), pois que caberá ao réu cumprir obrigação de fazer ou não fazer
determinada pelo juiz. No caso de improcedência, a sentença terá natureza
declaratória negativa, já que estará declarando que o réu não vulnerou os interesses
transindividuais sob tutela. A Lei $\mathrm{n}^{\circ} 7.347 / 1985$ só previu essas duas formas de
tutela. Todavia, a Lei no ${ }^{\circ} 8.078 / 1990$ (o Código do Consumidor) passou a admitir

${ }^{75}$ CARVALHO FILHO, José dos Santos. Manual de direito administrativo. $27^{\mathrm{a}}$ edição. São Paulo: Atlas, 2014. p. 1084-1085. 
hipóteses em que o pedido é o de anulação de atos ou de cláusulas contratuais. A Lei $n^{\circ}$ 8.625/1993 (Lei Orgânica Nacional do Ministério Público), a seu turno, também admite a ação civil pública para invalidação de atos. Em tais casos, a sentença que acolher a pretensão terá a natureza constitutiva (ou desconstitutiva), já que extinguirá relação jurídica anteriormente formada. Se improcedente a decisão, a sentença também será declaratória negativa."76

Rodolfo de Camargo Mancuso, por sua vez, assevera que:

“(...) a ação civil pública se afigura, em linha de princípio, de índole predominantemente cominatória, nesse sentido de ser vocacionada a comandos de fazer ou de se abster, ao passo que a efetividade real da prestação jurisdicional no campo das políticas públicas muitas vezes demandará um provimento de cunho mandamental. Mas a dificuldade poderá ser contornada no caso concreto, dependendo de como se faça, com engenho e arte, o pedido, por exemplo: em vez de pleitear que o judiciário ordene à administração pública ré que implemente tal ou qual sistema de despoluição de um rio, pode-se formular a pretensão no sentido de que o município venha condenado a abster-se de ali despejar esgoto não tratado" 77

Conforme depreende-se da leitura do artigo 16 da Lei 7347/85, conjugado com o art. 113 da Lei 8078/90, a sentença terá eficácia erga omnes, exceto a decisão de improcedência por falta de provas, a qual não faz coisa julgada material. Nessa hipótese específica, qualquer legitimado poderá ajuizar nova ação, inclusive com os mesmos fundamentos da anterior, e apresentar outras provas. ${ }^{78}$ Ressalta-se que a tramitação da ação coletiva não impede ou prejudica a propositura de ações individuais, conforme resta evidente nos $\S 1^{\circ}, 2^{\circ}$ e $3^{\circ}$ do artigo 113 do código de defesa do consumidor. Não há, assim, litispendência entre a ação coletiva e a individual, conforme prevê o art. 104 da Lei 8078/90. Sobre o regime diferenciado da coisa julgada na ação civil pública, ressalta-se o ensinamento de José dos Santos Carvalho Filho:

\footnotetext{
"Em relação à coisa julgada, repetimos aqui o que dissemos a respeito da ação popular, cujo art. 18 serviu de modelo para o art. 16 da Lei $n^{\circ} 7.347 / 1985$. Em termos idênticos, reza o dispositivo que a sentença civil fará coisa julgada erga

${ }^{76}$ Ibid. p. 1087.

77 MANCUSO, Rodolfo de Camargo. Ação civil pública: em defesa do meio ambiente, do patrimônio cultural e dos consumidores (lei 7.347/85 e legislação complementar). $10^{\mathrm{a}}$ edição. São Paulo: Revista dos Tribunais, 2007. p. 46.

${ }^{78}$ Ibid. p. 316.
} 
omnes, salvo no caso em que a ação for julgada improcedente por deficiência da prova, hipótese em que qualquer legitimado poderá ajuizar nova ação com o mesmo fundamento, socorrendo-se de nova prova. A regra será a produção da coisa julgada erga omnes. Será, todavia, inter partes quando a prova for deficiente, e nesse caso poderá ser ajuizada nova ação para o mesmo fim, recorrendo o autor à nova prova. Mais uma vez o legislador, por questão de política legislativa, preocupou-se em não deixar que o trânsito em julgado da decisão improcedente, por questão de prova, deixasse sem proteção, para o futuro, os interesses coletivos e difusos. Fixando esse efeito limitado, o legislador permite que tais interesses sejam defendidos em ação idêntica, na qual outra (e melhor) prova possa ser produzida para demonstrar a violação por parte do réu. Vigora aqui, mais uma vez, o princípio da renovabilidade da ação, calcado na relevância que merecem os interesses sob tutela." 79

Percebe-se, portanto, que a decisão em ação civil pública cujo objeto consista em direito difuso pode, não apenas reprimir a ocorrência de um dano, como também evitá-la. Relativamente ao alcance deste ato jurídico, os efeitos produzidos são estendidos a toda sociedade, observado o limite da competência territorial do órgão prolator, como dispõe o art. 16 da Lei $7347 / 85$.

\subsubsection{Fundo de Defesa de Direitos Difusos}

Em relação à liquidação e execução da sentença coletiva, o artigo 15 da Lei 7347/85 autoriza sua realização por qualquer co-legitimado, ficando o Ministério Público obrigado a promovê-la caso outro legitimado não o faça no prazo legal. No caso de o objeto da ação civil pública versar sobre direitos difusos, havendo condenação em dinheiro, o valor será destinado a um fundo específico, nos termos do artigo 13 da Lei 7347/85. A regulação do fundo federal de direitos difusos dá-se pela lei 9.008 e os Estados têm suas próprias leis regulando os fundos estaduais. No âmbito federal será gerido pelos Ministérios do Meio Ambiente e da Justiça, com a presença de representantes do Ministério Público e de associações civis. ${ }^{80}$ Em relação à execução,

\footnotetext{
${ }^{79}$ CARVALHO FILHO, José dos Santos. Manual de direito administrativo. $27^{\mathrm{a}}$ edição. São Paulo: Atlas, 2014. p. 1087-1088.

${ }^{80}$ MAZZILLI, Hugo Nigro. A defesa dos interesses difusos em juízo: meio ambiente, consumidor, patrimônio cultural, patrimônio público e outros interesses. 30. ed. São Paulo: Saraiva, 2017. p. 641-648.
} 
aplica-se o código de processo civil naquilo que for compatível com os preceitos da tutela coletiva.

\title{
2.5. Ação Civil Pública na Esfera do Processo Coletivo na Busca da Promoção do Interesse Público Primário
}

Inicialmente, é preciso compreender a afirmativa sobre ser o processo coletivo um processo de interesse público, como destacam Fredie Didier Junior e Hermes Zaneti Junior que compreendem o processo coletivo como “espécie de processo de interesse público”:

\begin{abstract}
"Os processos coletivos servem à "litigação de interesse público" (LIP); ou seja, servem às demandas judiciais que envolvam, para além dos interesses meramente individuais, aqueles referentes à preservação da harmonia e à realização dos objetivos constitucionais da sociedade e da comunidade. Interesses de uma parcela da comunidade constitucionalmente reconhecida, a exemplo dos consumidores, do meio ambiente, do patrimônio artístico, histórico e cultural, saúde, educação, bem como na defesa dos interesses dos necessitados e dos interesses minoritários nas demandas individuais clássicas (não os dos habituais polos dessas demandas, credor/devedor), como os das crianças e adolescentes, das pessoas institucionalizadas em hospitais e presídios, dos negros, dos índios, das mulheres, podem ser passíveis de serem vinculados como situações jurídicas coletivas merecedoras de tutela através de ações coletivas que permitam a tutela molecular de todo o grupo." 81
\end{abstract}

Sendo assim, cabe realizar breve consideração sobre o interesse público, por possuir conceituação jurídica de difícil apreensão, ${ }^{82}$ indeterminada. $\mathrm{O}$ interesse público, de acordo com a doutrina ${ }^{83}$, pode ser caracterizado como primário ou secundário. Quanto aos interesses primários, estes vinculam a administração pública e consubstanciam-se em princípios e valores que a norteiam, ínsitos às suas finalidades constitucionais e à ordem pública, são valores que preponderam no meio social. Os direitos difusos, nesse sentido, são um exemplo, seja pela dimensão e alcance do ilícito, do

\footnotetext{
${ }^{81}$ DIDIER Jr, Fredie, ZANETI Jr, Hermes. Curso de Direito Processual Civil: Processo Coletivo. $12^{\mathrm{a}}$ edição, volume 4. Salvador, BA: JusPODIVM, 2018. p. 38.

${ }^{82}$ Há controvérsias doutrinárias sobre sua determinabilidade, contudo não se adentrará neste mérito. ${ }^{83}$ MOREIRA NETO, Diogo de Figueiredo. Curso de Direito Administrativo. 16 $6^{\text {a }}$ edição. Rio de Janeiro: Forense, 2014. p. 95-97.
} 
dano, dos valores associados e dos bens jurídicos tutelados, como pelo número de pessoas atingidas.

Há, assim, a função social do Estado e evidente indisponibilidade dos direitos correlatos, ou seja, não podem ser objetos de renúncia, alienação e transação. Nestes casos, por exemplo, verificada a violação ao direito pela Administração Pública, cabe aos legitimados da sociedade civil provocarem o Judiciário para que este realize o controle jurisdicional de políticas públicas. Portanto, os poderes constituídos possuem o dever de observar o interesse público primário, o qual confere legitimidade à sua atuação. Enfim, o interesse público primário abrange direitos fundamentais e está intimamente associado ao interesse social, da coletividade. ${ }^{84}$

O interesse público secundário, por sua vez, consiste nos meios através dos quais o Estado se vale para atingir seus objetivos. São os interesses da administração pública enquanto sujeito de direito. Os direitos, neste caso, são disponíveis, em geral possuem natureza patrimonial e relacionam-se a questões financeiro-orçamentárias. Ressalta-se, ainda, que ao atender ao interesse público o Estado não se sobrepõe arbitrariamente ao interesse privado, terá que seguir a legalidade, atentar aos princípios e direitos fundamentais constitucionais igualmente relevantes, sob pena de violação à própria Constituição. ${ }^{85}$

Seguindo esta linha assinala Fredie Didier Jr. que:

"A defesa do interesse público primário por meio de processos cíveis, inclusive na
atuação de controle e realização de políticas públicas, permite falar aqui de uma
expansão da tradicional judicial review brasileira voltada ao controle dos atos da
administração e da constitucionalidade das leis em casos individuais, para uma

${ }^{84}$ MAZZILLI, Hugo Nigro. A defesa dos interesses difusos em juízo: meio ambiente, consumidor, patrimônio cultural, patrimônio público e outros interesses. 30. ed. São Paulo: Saraiva, 2017. p. 4952.

${ }^{85}$ Parte significativa da doutrina mais atual compreende que as esferas, público e privada não são antagônicas, pelo contrário, são interligadas e complementares. Desse modo, não haveria que se considerar, a priori, a supremacia de um interesse sobre o outro, mas, a partir da ponderação dos bens jurídicos em questão, analisar à luz do caso concreto e do ordenamento jurídico a solução mais adequada e consentânea às disposições e finalidades constitucionais. O que ocorre, na realidade, é a disputa entre interesses privados e coletivos. Sobre o tema: LEITE, Carlos Henrique Costa. A supremacia do interesse público sobre o privado e os conceitos jurídicos fundamentais de Wesley Hohfeld. Revista Jus Navigandi, ISSN 1518-4862, Teresina, ano 16, n. 3069, 26 nov. 2011. Disponível em: <https://jus.com.br/artigos/20509>. Acesso em: 4 jun. 2018. 
judicial review em defesa de direitos coletivos, permitindo o controle e a adequação dos atos da administração pública e do poder legislativo à luz do direito material coletivo, tutelando todos os membros do grupo, de forma indistinta. A Litigação de Interesse Público nesses casos visa a medidas estruturantes, postuladas por meio de ações coletivas ou certificadas em compromissos de ajustamento de conduta (acordo coletivo celebrado por órgão público legitimado à tutela coletiva) que permitam coordenar as atividades pela intervenção dos órgãos de garantia (ministério público e poder judiciário) até a satisfação integral da tutela do direito coletivo."

(...)

"A complexidade da matéria envolvida na implementação e aplicação de políticas públicas força a migração de um modelo meramente responsivo e repressivo do poder judiciário, modelo de atuação posterior aos fatos já ocorridos para aplicação da norma jurídica; para um modelo resolutivo e participativo, que pode anteceder aos fatos lesivos e resultar na construção conjunta de soluções jurídica adequadas. Essa mudança está amplamente amparada pela ótica do processo civil do Estado Democrático Constitucional adotada pelo CPC, a exemplo dos princípios da solução consensual, da primazia do julgamento de mérito, da boa-fé processual objetiva e da cooperação (artigos 3, 4, 5 e 6 do CPC), mas é ainda mais necessária para solução dos problemas surgidos em razão da sindicabilidade judicial de políticas públicas por meio de ações coletiva. A partir daí começaram a surgir na doutrina discussões sobre o modelo experimentalista de reparação, através do qual o juiz abre mão da centralidade no processo, reconhecendo a complexidade do problema da escolha das medidas necessárias, trazendo para o processo a ampla participação de todos os envolvidos, inclusive a sociedade civil, para delimitação de um programa de resolução do conflito. Assim, são tomadas decisões mais flexíveis e provisórias, com inclusão dos envolvidos na supervisão das medidas adotadas, com a possibilidade de contínuas revisões para adequação dessas medidas aos problemas surgidos ao longo de sua implementação, iniciando-se por decisões estruturantes (organizativas) que estabeleçam metas, objetivos e parâmetros de controle do cumprimento e da efetividade das medidas judicias adotadas."

(...)

"A própria noção de execução muda, passando a ser exigida a execução civil desdobrada no tempo, e execução das chamadas "medidas judiciais estruturantes". Essas medidas são voltadas para a tutela específica das obrigações, muito além da pretensão obrigacional de satisfação de um crédito em dinheiro. trata-se de medidas de performance específica (specific performance) em decisões com caráter estruturante (structural injunctions), adotando-se, na espécie, um modelo muito parecido com o modelo de execução do common law, voltado para a adequação da medida executiva às necessidades práticas de efetivação. A noção experimentalista e as medidas estruturantes permitem a um só tempo o conhecimento colaborativo do problema pelas partes e pelo juiz (colaborative learning) e uma maior responsabilização e legitimação democrática (democratic accountability), visando à efetividade da decisão judicial." ${ }^{86}$

\section{O objeto da ação civil pública é amplo e também alcança as políticas}

públicas. Segundo Rodolfo de Camargo Mancuso, a doutrina e jurisprudência mais recentes reconhecem cada vez mais a possibilidade de realizar o

${ }^{86}$ DIDIER Jr, Fredie, ZANETI Jr, Hermes. Curso de Direito Processual Civil: Processo Coletivo. $12^{\mathrm{a}}$ edição, volume 4. Salvador, BA: JusPODIVM, 2018. p. 39-41. 
controle judicial de atos administrativos. Reduz-se, então, o campo de atuação estritamente discricionária do agente político, compreendendo-se, assim, que:

\begin{abstract}
“(...) a grande maioria dos atos administrativos, em sentido largo, é de algum modo vinculada, seja porque seu agente está no exercício de um múnus público, seja pela própria natureza desses atos de gestão, seja pela precípua indisponibilidade do interesse público." 87
\end{abstract}

Esta sindicabilidade judicial pode atingir não só atos comissivos, mas também omissivos, especialmente visando a efetivação de políticas públicas indispensáveis à ordem social e à eficácia de direitos e garantias constitucionais, como exemplo no caso do direito à educação e à saúde. Assim, seria possível a ação civil pública determinar à Administração Pública uma obrigação de fazer que acarrete em despesas, como por exemplo a prestação de um serviço público essencial previsto em lei, como no caso do saneamento.

Nesse sentido, através da ação civil pública, busca-se tão somente a execução de medidas garantidoras de direitos fundamentais já consagrados constitucionalmente, previstas em leis infraconstitucionais. Portanto a intervenção na esfera típica de outro Poder da República seria legítima a medida em que se propõe conferir eficácia social às normas jurídicas. ${ }^{88}$ Assim, a ação civil pública torna-se ferramenta que possibilita assegurar a concretização de políticas públicas voltadas para a promoção de direitos sociais, como é o caso do acesso ao adequado serviço público de saneamento básico, que é garantido por lei. ${ }^{89}$

\footnotetext{
${ }^{87}$ MANCUSO, Rodolfo de Camargo. Ação civil pública: em defesa do meio ambiente, do patrimônio cultural e dos consumidores (lei 7.347/85 e legislação complementar). $10^{\mathrm{a}}$ edição. São Paulo: Revista dos Tribunais, 2007. p. 43-44.

${ }^{88}$ Este tema será especificamente tratado no capítulo 3. Contudo, ressalta-se que essa intervenção do judiciário deve ser temperada e balizada por critérios rígidos e claros, a fim de impedir distorções e ingerências indevidas nas competências do Poder Executivo ou Legislativo. Não se pretende determinar, pelo Judiciário, o juízo de oportunidade e conveniência da Administração Pública.

${ }^{89}$ Op. Cit. p. $45-48$.
} 


\section{Capítulo 3. Ação Civil Pública como Meio Processual para Concretização do Acesso ao Serviço de Saneamento Básico pela Via Judicial e a Reserva do Possível}

\subsection{Direito ao Saneamento Básico e Controle de Políticas Públicas}

A Constituição Federal estabelece, quando dispõe a respeito dos direitos e garantias fundamentais, no artigo $5^{\circ}, \S 1^{\circ}$, a aplicabilidade imediata das normas que versam sobre direitos e garantias fundamentais, consistindo em comando que visa à máxima eficácia desses direitos. Essa constatação, à luz do caso concreto, impõe ao julgador uma interpretação sistemática do ordenamento jurídico. Desse modo, sendo o saneamento básico um direito social, este gera um direito de prestação e configura um poder-dever ao administrador público e ao legislador, pois há Lei Nacional editada, assim, não é apenas uma promessa, mas norma exigível, que necessariamente deve ser efetivada pelo Estado. O direito ao saneamento básico, contudo, encontra desafios à sua eficácia social em razão de limites fáticos orçamentários. ${ }^{90}$

Não obstante a condicionante orçamentária, a não concretização dos ditames da política pública de saneamento básico significa atentar contra a dignidade humana, a saúde, o meio ambiente e a qualidade de vida. Nesse sentido, os serviços públicos de saneamento básico são urgentes e essenciais. Vinculam o Poder Público por previsão na Constituição, como também na legislação infraconstitucional. Logo, observados certos critérios, a atuação dos agentes públicos nesse campo é passível de controle pelo Judiciário, pois a efetivação do saneamento básico é indispensável para o exercício de tantos outros direitos.

Sendo assim, como condição para uma compreensão mais clara da natureza da atuação judicial na efetivação de direitos sociais prestacionais

\footnotetext{
${ }^{90}$ SARLET, Ingo Wolfgang. A eficácia dos direitos fundamentais: uma teoria geral dos direitos fundamentais na perspectiva constitucional. 12. ed. rev. atual e ampl. Porto Alegre: Livraria do Advogado, 2015. p. 297.
} 
através de ações civis públicas impende, inicialmente, explicitar o significado corrente da expressão "políticas públicas". Nesse sentido, cabe destacar que, segundo Estefânia Maria de Queiroz Barboza e Katya Kozicki $^{91}$, políticas públicas podem ser compreendidas como propósitos coletivos lato sensu materializados a partir de ações positivas do Estado, o qual tem sua atuação vinculada à consecução dessas, sobretudo no âmbito dos direitos sociais.

Adda Pellegrini Grinover ${ }^{92}$, por sua vez, define políticas públicas como o conjunto de atividades estatais, delineadas pelos poderes da República, primordialmente pelos Poderes Executivo e Legislativo, direcionadas para o atingimento dos objetivos do Estado.

Andreas Joachim Krell13 assinala que cabe precipuamente ao legislador e ao administrador, por meio de sua "liberdade de conformação", estabelecer sobre que parâmetros dar-se-á efetividade aos direitos sociais. Dessa compreensão, extrai-se o caráter excepcional da interferência judicial no âmbito das competências discricionárias de outro poder, que ocorrerá quando constatadas claras situações de ilegalidade e inconstitucionalidade.

Daniel Sarmento ${ }^{94}$, também destaca que incumbe primordialmente, em observância às funções típicas e à "capacidade institucional superior”, ao legislador e administrador público a tarefa de concretizar as garantias associadas ao mínimo existencial através da realização de políticas públicas. Ressalta, no entanto, que é legítima a intervenção, a posteriori, do Judiciário para corrigir eventuais falhas no cumprimento desse poder-dever constitucional atribuído ao Poder Público.

\footnotetext{
${ }^{91}$ BARBOZA, Estefânia Maria de Queiroz; KOZICKI, Katya. Judicialização da política e controle judicial de políticas públicas. Revista Direito GV, vol. 8, no 1, 2012. p. 72.

${ }^{92}$ GRINOVER, Ada Pellegrini. O controle das políticas públicas pelo poder judiciário. Revista do Curso de Direito da Faculdade de Humanidades e Direito, v. 7, n. 7, 2010. p. 6 e 9.

93 KRELL, Andreas Joachim. Realização dos direitos fundamentais sociais mediante controle judicial da prestação dos serviços públicos básicos: (uma visão comparativa). Revista de Informação Legislativa, Brasília vol. 36, n 144, 1999. p241.

94 SARMENTO, Daniel. O mínimo existencial / The right to basic conditions of life. Revista de Direito da Cidade, [S.1.], v. 8, n. 4, p. 1644- 1689, nov. 2016. p. 1664-1665, 1669-1670.
} 
Assim, embora caiba precípua e tipicamente ao legislador e administrador público determinar a aplicação e alocação de recursos públicos, bem como executar as respectivas políticas públicas, em caso de exercício irregular do poder - ainda que no âmbito do poder discricionário, pois a atuação dos agentes públicos deve coadunar com as finalidades constitucionais - os tribunais possuem legitimidade e competência para realizar o controle de políticas - avaliar a qualidade ou ausência de prestação de serviços públicos - e a destinação de recursos públicos, bem como impor prestações positivas ao poder público com o intuito de concretizá-los e tornálos mais eficientes. Isso evidencia o fenômeno de judicialização da política. ${ }^{95}$ Portanto, espera-se que o Poder Executivo administre para atender ao interesse público e cumpra seu papel determinado pela Constituição, cabendo ao Judiciário, quando devidamente provocado, realizar o controle da adequação dos atos administrativos e legislativos ao ordenamento jurídico ${ }^{96}$, como a observância ou não aos princípios constitucionais da moralidade, legalidade e eficiência, vide art. 37 da CRFB/88. Enfim, sobre a relação entre o sentido e finalidade das políticas públicas e a atuação do Estado, vale destacar que:

\begin{abstract}
"Considerando as políticas públicas como o conjunto de ações estatais, por meio das quais são traçadas as diretrizes e metas a serem fomentadas pelo Estado, sobretudo na implementação dos objetivos e direitos fundamentais dispostos na Constituição, o controle judicial da Administração Pública não se deve restringir simplesmente ao controle estrito da legalidade. Os atos normativos e administrativos vinculadores de políticas públicas devem observar os princípios constitucionais e os pressupostos do Estado Democrático de Direito como um todo. Dessa forma, amplia-se a atuação do Judiciário no controle do ato administrativo. Aquilo que outrora se restringia à legalidade e de maneira mecânica afastava a
\end{abstract}

\footnotetext{
${ }^{95}$ RIBEIRO DA SILVA, Airton; PINTO WEIBLEN, Fabrício. A reserva do possível e o papel do judiciário na efetividade dos direitos sociais. Revista Eletrônica do Curso de Direito da UFSM, Santa Maria, RS, vol. 2, n' 2, agosto de 2007. p. 48

96 Sobre as hipóteses de violação à ordem jurídica, vale destacar o art. $2^{\circ}$ da Lei 4717/65, que dispõe, in verbis: Art. $2^{\circ}$ São nulos os atos lesivos ao patrimônio das entidades mencionadas no artigo anterior, nos casos de: (...) c) ilegalidade do objeto; d) inexistência dos motivos; e) desvio de finalidade. Parágrafo único. Para a conceituação dos casos de nulidade observar-se-ão as seguintes normas: (...) c) a ilegalidade do objeto ocorre quando o resultado do ato importa em violação de lei, regulamento ou outro ato normativo; d) a inexistência dos motivos se verifica quando a matéria de fato ou de direito, em que se fundamenta o ato, é materialmente inexistente ou juridicamente inadequada ao resultado obtido; e) o desvio de finalidade se verifica quando o agente pratica o ato visando a fim diverso daquele previsto, explícita ou implicitamente, na regra de competência.
} 
apreciação do núcleo do ato, passa agora a demandar a aferição da compatibilidade do mérito do ato administrativo com os princípios constitucionais. Ainda dentro dessa perspectiva de análise, é essencial reconhecer que existe uma efetiva separação entre as funções estatais que deve ser mantida, mas ela está condicionada aos objetivos e direitos fundamentais que orientam a Constituição, os quais gozam de plena força normativa, vinculando todos os poderes constituídos. Portanto, o controle judicial das políticas públicas encontra seu refúgio fundamental na Constituição de 1988. A omissão ou inadimplência dos Poderes Legislativo e Executivo na implementação de políticas públicas realizadoras de direitos fundamentais passa a ser uma questão constitucional." ${ }^{\text {97 }}$

A atuação do Judiciário para fins de controle e correção dos atos praticados pelo Poder Executivo e Legislativo, é preciso ressaltar, possui assento constitucional e legal, como a inafastabilidade da jurisdição, insculpida no artigo $5^{\circ}$, inciso XXXV da CFRB/88. Portanto, associar, $a$ priori, o fenômeno da judicialização da política com o usual estereótipo negativo atribuído ao ativismo judicial constitui-se um equívoco ${ }^{98}$. A judicialização da política pauta-se na ocorrência de legítimas demandas judiciais cujo deslinde requer intervenção, com fundamento no ordenamento jurídico, do Poder Judiciário na seara Política, observe-se:

\begin{abstract}
"No âmbito da judicialização da política, portanto, o simples fato de se adotar uma decisão desta natureza não pode ser considerada ativista. Alguns comportamentos adotados nesta seara podem ser assim enquadrados a partir de alguns critérios, como quando o Poder Judiciário adentra em determinada questão política ainda que os Poderes estatais não tenham se omitido; quando eventual lesão a direito fundamental decorreu da impossibilidade fática do Estado em garanti-lo e não de seu descaso; quando os Poderes Executivo e Legislativo atuaram de forma razoável na implementação do direito social, tendo adotado políticas públicas eficazes; bem como quando o legislador atuou dentro do livre espaço de conformação que lhe foi outorgado pela Constituição, com a observância da margem de discricionariedade a que estava adstrito." 99
\end{abstract}

\footnotetext{
${ }^{97}$ GRANDO, Fabiane. O controle judicial das políticas públicas. Revista Internacional Consinter de Direito ano I, $\mathrm{n}^{\circ} \mathrm{I}$, p. 499-516, $2^{\circ}$ semestre de 2015. p. 508-509.

${ }^{98} \mathrm{O}$ ativismo judicial é comumente relacionado a atuações proativas do Poder Judiciário que extrapolam suas competências funcionais insculpidas no ordenamento jurídico e que tendem a violar, dentre outros preceitos, os princípios constitucionais democrático e da separação dos poderes. Portanto, é preciso ter-se cautela ao analisar essa atuação do Judiciário quando do controle de políticas públicas, pois configura-se um equívoco associá-la, aprioristicamente, a um "ativismo judicial" que inobserva a legitimidade democrática dos representas eleitos pelo povo, na medida em que os juízes careceriam de legitimidade e competência para atuar nessa seara.

99 BICCA, Carolina Scherer. Judicialização da Política e Ativismo Judicial. Revista de Direito Brasileira, vol. 2, n 2, 2012. p. 138.
} 
A atuação pautada em critérios objetivos e comprometida com a ordem jurídica não macula a intervenção judicial, pelo contrário, demonstra maturidade institucional e reconhecimento da necessária justiça social, efetividade dos direitos sociais. Não há procedência no argumento de que o princípio da Separação dos Poderes, insculpido no artigo $2^{\circ}$ da CRFB/88, constitui óbice à intervenção judicial no campo das políticas públicas. Inicialmente, há que se ter em conta que o princípio da separação dos poderes pressupõe a existência de controles recíprocos entre os Poderes Legislativo, Executivo e Judiciário, o sistema de freios e contrapesos. ${ }^{100}$ A própria dicção do dispositivo constitucional, ao afirmar que os Poderes são independentes e harmônicos entre si, não prevê uma separação absoluta, mas um regime de complementação, de permeabilidade e controle mútuo entre os mesmos, para cumprimento dos objetivos da Constituição Federal.

Ou seja, "a separação dos poderes não é um fim em si mesmo"101, deve coexistir harmonicamente com outros princípios constitucionais - dos quais inclusive extrai seu substrato valorativo, como os direito fundamentais, que norteiam o Estado Democrático de Direito - e não justificar ou impedir que o judiciário, devidamente provocado, atue positivamente para conferir eficácia jurídica e social a direitos sociais. Assim, esse princípio é interpretado não como uma absoluta divisão, mas um sistema que visa ao equilíbrio de forças. ${ }^{102}$ Embora cada poder tenha suas atribuições típicas, isso não pode significar, na prática, a não possibilidade de correção de situações flagrantemente inconstitucionais.

Também não há impedimento quanto à legitimidade democrática do Judiciário. Na defesa das minorias e da ordem constitucional, o Poder Judiciário tem legitimidade para atuar de forma contra majoritária. Por exemplo, ao tutelar os direitos sociais, na busca pela isonomia material entre

\footnotetext{
${ }^{100}$ BARCELLOS, Ana Paula de. A eficácia jurídica dos princípios constitucionais: O princípio da dignidade humana. $3^{\mathrm{a}}$ ed. revista e atualizada. Rio de Janeiro: Renovar, 2011. p. 268-270.

${ }^{101}$ Ibid. p. 262-264.

${ }^{102}$ MAZZILLI, Hugo Nigro. A defesa dos interesses difusos em juízo: meio ambiente, consumidor, patrimônio cultural, patrimônio público e outros interesses. 30. ed. São Paulo: Saraiva, 2017. p. 186-187.
} 
os indivíduos, o princípio majoritário não impede que se adentre o campo das políticas públicas.

\title{
3.2. Direitos Sociais Prestacionais e a Reserva do Possível
}

A reserva do possível pode ser compreendida como a incapacidade do Estado em atender a todas as ilimitadas necessidades e demandas sociais, diante da limitabilidade dos recursos disponíveis para tanto. $\mathrm{O}$ alcance desse instituto abrange não apenas a possibilidade de escassez das finanças públicas, os limites orçamentários do erário, como também a razoabilidade da pretensão exigida perante o Estado. Sobre a definição do que se entendo por reserva do possível, vale destacar o ensinamento de Ingo Wolfgang Sarlet:

\begin{abstract}
"A partir do exposto, há como sustentar que a assim designada reserva do possível apresenta pelo menos uma dimensão tríplice, que abrange a) a efetiva disponibilidade fática dos recursos para a efetivação dos direitos fundamentais; b) a disponibilidade jurídica dos recursos materiais e humanos, que guarda íntima conexão com a distribuição de receitas e competência tributarias, orçamentarias, legislativas e administrativas, entre outras, e que, além disso, reclama equacionamento, notadamente no caso do Brasil, no contexto do nosso sistema constitucional federativo; c) já na perspectiva (também) do eventual titular de um direito a prestações sociais, a reserva do possível envolve o problema da proporcionalidade da prestação, em especial no tocante à sua exigibilidade e, nesta quadra, também da sua razoabilidade." 103
\end{abstract}

A reserva do possível no âmbito jurídico, por exemplo, visa à observância das normas orçamentárias quando da confluência com direitos sociais prestacionais. ${ }^{104}$ No aspecto fático relaciona-se a ausência absoluta de recursos para adimplir a obrigação de efetivar as ações exigidas. Ou seja, consiste na impossibilidade, de ordem material, do Estado prestar, a todos, o

\footnotetext{
103 SARLET, Ingo Wolfgang. A eficácia dos direitos fundamentais: uma teoria geral dos direitos fundamentais na perspectiva constitucional. 12. ed. rev. atual e ampl. Porto Alegre: Livraria do Advogado, 2015. p. 296.

${ }^{104}$ BARCELLOS, Ana Paula de. A eficácia jurídica dos princípios constitucionais: O princípio da dignidade humana. $3^{\mathrm{a}}$ ed. revista e atualizada. Rio de Janeiro: Renovar, 2011. p. 277-278.
} 
direito exigido ${ }^{105}$. Caso seja inviável, essa condição de realidade simplesmente não viabiliza, de imediato, a integral garantia das prestações formuladas, pois a escassez de recursos é um problema que extrapola o âmbito do Direito.

Ingo Wolfgang Sarlet ${ }^{106}$ salienta que os direitos sociais prestacionais, através do sopesamento de diferenças de ordem material e fornecimento adequado de serviços e bens a toda a população, visam promover a justiça social. Afirma que todos esses elementos da reserva do possível associam-se a princípios constitucionais e demandam, conjuntamente, um juízo de adequação a fim de preservar, ao máximo, os efeitos concretos dos direitos fundamentais. Nesse sentido, não consistiria a reserva do possível em um obstáculo aos direitos sociais prestacionais, mas um meio de assegurá-los. Além disso, entende que a reserva do possível não é um valor e limite indissociável aos direitos fundamentais. Sobre esse ponto, destaca:

\footnotetext{
"A reserva do possível constitui, em verdade (considerada toda sua complexidade), espécie de limite jurídico e fático dos direitos fundamentais, mas também poderá atuar, em determinadas circunstâncias, como garantia dos direitos fundamentais, por exemplo, na hipótese de conflitos de direitos, quando se cuidar da invocação observados sempre os critérios da proporcionalidade e de garantia do mínimo existencial em relação a todos os direitos - da indisponibilidade de recursos com o intuito de salvaguardar o núcleo essencial de outro direito fundamental."107
}

Em sentido similar, afirma Ana Paula de Barcellos ${ }^{108}$ que a reserva do possível deve ser interpretada à luz dos valores do Estado Democrático de Direito previstos na Constituição. Nesse sentido, o orçamento deve refletir as diretrizes constitucionais, o que significa no campo dos direitos sociais a proibição do excesso ou da proteção insuficiente desses direitos, havendo a

\footnotetext{
105 SARMENTO, Daniel. O mínimo existencial / The right to basic conditions of life. Revista de Direito da Cidade, [S.1.], v. 8, n. 4, nov. 2016. p. 1672-1673.

106 SARLET, Ingo Wolfgang. A eficácia dos direitos fundamentais: uma teoria geral dos direitos fundamentais na perspectiva constitucional. 12. ed. rev. atual e ampl. Porto Alegre: Livraria do Advogado, 2015. p. 225.

${ }^{107}$ Ibid. p. 296.

108 BARCELLOS, Ana Paula de. A eficácia jurídica dos princípios constitucionais: O princípio da dignidade humana. $3^{\mathrm{a}}$ ed. revista e atualizada. Rio de Janeiro: Renovar, 2011. p. 282-284.
} 
prioridade das pretensões relativas ao mínimo existencial quando comparadas a outras despesas realizadas pelo Estado.

$\mathrm{O}$ entendimento prevalecente na jurisprudência brasileira ${ }^{109}$ consiste em estabelecer que a recusa de cumprimento da obrigação pelo Estado sob o argumento da reserva do possível não pode ser genérica, devendo haver comprovação da inexistência de recursos por parte do ente federativo. ${ }^{110}$ Além disso, mesmo diante do cenário no qual os recursos econômicofinanceiros, naturalmente escassos, são contrapostos a demandas sociais ilimitadas, cumpre ao agente público a manutenção das condições mínimas (mínimo existencial) de fruição dos direitos fundamentais. Logo, nesses casos, "justifica-se um escrutínio muito mais rigoroso do Poder Judiciário sobre as escolhas alocativas e desalocativas dos poderes públicos, para que se verifique a sua compatibilidade com prioridades que derivam da própria Constituição. ",111

Ante ao exposto até agora, percebe-se que a atuação do Judiciário no campo das políticas públicas, para garantia de direitos fundamentais, é juridicamente possível e deverá pautar-se nos princípios da dignidade humana e do mínimo existencial.

\subsection{Critérios: Ponderação, Razoabilidade e Proporcionalidade}

Sendo assim, a teoria do discurso ${ }^{112}$, que engloba as técnicas da argumentação jurídica e da ponderação, é de suma importância

\footnotetext{
109 Vide: STJ, Recurso Especial $n^{\circ}$ 1.150.392, Rel. Min. Sérgio Kukina, Brasília (DF), 13 de setembro de 2016; STF, Medida Cautelar na Arguição de Descumprimento de Preceito Fundamental $n^{\circ}$ 45, $1^{\text {a }}$ Turma, Rel. Min. Celso de Mello, Brasília (DF), 29 de abril de 2004; TJMG, Apelação

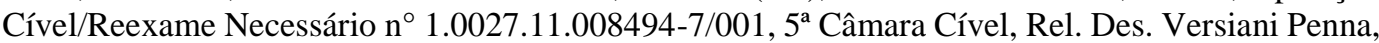
Belo Horizonte (MG), 18 de dezembro de 2014; TJRJ, Apelação Cível $\mathrm{n}^{\circ}$ 002249008.2012.8.19.0001, 6 ${ }^{\text {a }}$ Câmara Cível, Rel. Des. Claudia Pires dos Santos Ferreira, de 2015.

${ }^{110}$ HENNIG LEAL, Mônia Clarissa; SCHNORR ALVES, Fernando Roberto. Razoabilidade $e$ Teoria da Reserva do Possível como Fundamentos para o Controle Jurisdicional de Políticas Públicas: Uma Análise a partir da Teoria do Discurso. Espaço Jurídico Journal of Law, vol. 17, $\mathrm{n}^{\circ}$ 2, 2016. p. 592.

${ }^{111}$ SARMENTO, Daniel. O mínimo existencial / The right to basic conditions of life. Revista de Direito da Cidade, [S.1.], v. 8, n. 4, nov. 2016. p. 1674.

${ }^{112}$ HENNIG LEAL, Mônia Clarissa; SCHNORR ALVES, Fernando Roberto. Razoabilidade $e$ Teoria da Reserva do Possível como Fundamentos para o Controle Jurisdicional de Políticas
} 
especialmente nesses casos de garantia de direitos fundamentais através da intervenção do Judiciário, pois aos prever critérios objetivos, possibilita uma análise racional e bem fundamentada do caso, conferindo maior exequibilidade e conformidade das decisões judiciais com o ordenamento jurídico. A proporcionalidade, nesse contexto, figura como critério para obter o melhor resultado da forma menos gravosa, na adequação entre meios e fins. Este princípio, por sua vez, subdivide-se nos postulados da adequação, necessidade e proporcionalidade em sentido estrito.

A adequação consiste na restrição parcial de algum direito para promover outros bens jurídicos de igual valor, de modo que as vantagens decorrentes dessa decisão superem as desvantagens. Já a necessidade, significa na opção, dentre as possíveis e legítimas escolhas para solucionar o caso, pela menos nociva ao direito mitigado, em relação a qual também devese demonstrar a urgência e utilidade da medida. A proporcionalidade em sentido estrito, por sua vez, é o sopesamento dos valores envolvidos para afirmar qual deles preponderará no caso. Assim equilibrar-se-á, através de uma gradação quanto a importância da satisfação de um direito e a afetação dos demais valores. Em suma, visa-se aplicar a norma ao caso concreto com equidade. $^{113}$

A técnica da ponderação por sua vez, compreende que a norma jurídica é composta por regras e princípios, de modo que a interpretação e aplicação dos dispositivos constitucionais e infraconstitucionais seja realizada considerando-se "valores jurídicos suprapositivos, no qual as ideias de justiça e de realização dos direitos fundamentais desempenham um papel central." 114 Essa abordagem acerca da norma jurídica conduz, com frequência, a colisão de princípios de similar hierarquia e relevância. Sendo assim, recorre-se à ponderação, técnica de interpretação através da qual "à

Públicas: Uma Análise a partir da Teoria do Discurso. Espaço Jurídico Journal of Law, vol. 17, $\mathrm{n}^{\circ}$ 2, 2016. p. 604.

113 Ibid. p. 598-600.

114 BARROSO, Luis Roberto; BARCELlOS, Ana Paula de. O começo da história. A nova interpretação constitucional e o papel dos princípios no direito brasileiro. Revista de Direito Administrativo, Rio de Janeiro, v. 232, 2003. p. 148. 
vista do caso concreto, o intérprete irá aferir o peso que cada princípio deverá desempenhar na hipótese, mediante concessões recíprocas, e preservando o máximo de cada um, na medida do possível. "115 Isso significa observar a máxima da menor restrição possível de princípios, a fim de preservar seu núcleo essencial, a eficácia do preceito básico nele contido. Assim, em caso de conflito de princípios, a aplicação de um deles não excluirá, por completo, a dos outros, havendo que se considerar, para tanto, as contingências fáticas e jurídicas.

Nesse sentido, o direito ao saneamento básico, enquanto direito social prestacional inclui-se no rol de direitos fundamentais. Desse modo, a partir do caso concreto, será apurada sua aplicabilidade e extensão, assim como analisar-se-á, observando certas balizas e à luz do ordenamento jurídico, a corretude ou não dos atos e critérios da Administração Pública ao aplicar os recursos públicos e dispô-los no orçamento.

Caso sejam constatadas violações, caberá ao Judiciário exercer sua função jurisdicional e tutelar adequadamente os direitos e interesses envolvidos. Assim, o disposto no artigo $5^{\circ}, \S^{\circ}$ da CRFB/88 só é mitigado excepcionalmente e temporariamente em caso devidamente justificado em razão de inviabilidade de ordem material, comprovável pelo poder público, pois a este incumbe o dever de efetivar esses direitos e diretrizes respeitando o mínimo existencial.

Andreas Joachim Krell afirma que as normas constitucionais que versam sobre direitos fundamentais constituem expressões vagas, de conceito indeterminado e, por isso, requerem uma interpretação valorativa e ponderada, de modo que o tradicional método lógico de subsunção, torna-se insuficiente para tutelar o direito material, nesses casos. Ou seja, interpretar juridicamente direitos fundamentais "deixa de ser um problema de correta subsunção do fato à norma para se tornar um problema de conformação

${ }^{115}$ Ibid. p. 149. 
política dos fatos, isto é, de sua transformação conforme um projeto ideológico (e não lógico)." 116

\title{
3.4. Controle Jurisdicional de Políticas Públicas, via Ação Civil Pública, envolvendo o Saneamento Básico: Análise de Decisões Judiciais
}

Ante ao exposto até o presente ponto, cabe avaliar como esse conteúdo formal, doutrinário e teórico é aplicado, na prática, pelo Poder Judiciário. Neste tópico, portanto, pretende-se realizar uma análise da jurisprudência, de alguns tribunais de Justiça, acerca de ações civis públicas que envolvam pretensões relativas à efetivação dos serviços públicos de saneamento básico.

Inicialmente, cumpre destacar a decisão do Superior Tribunal de Justiça em sede de Recurso Especial n ${ }^{\circ} 1.220 .669^{117}$, de relatoria do Ministro Herman Benjamin, no qual o STJ assentou que o direito ao saneamento básico é um poder-dever do Estado e que este, ao imiscuir-se do seu efetivo cumprimento, sujeita-se ao controle judicial de legalidade dos atos da Administração Pública. Destaca-se, então, a seguinte parte da Ementa do acórdão supracitado:

\begin{abstract}
"SANEAMENTO. PROCESSUAL CIVIL. AÇÃO CIVIL PÚBLICA. CONTROLE JUDICIAL DE ATOS DO EXECUTIVO. LEGALIDADE. DEVERPODER ESTATAL PASSÍVEL DE CONTROLE JUDICIAL. LEI 11.445/2007 (LEI DA POLÍTICA FEDERAL DE SANEAMENTO BÁSICO). CARÊNCIA AFASTADA. 1. Trata-se na origem de Ação Civil Pública oriunda de lançamento de dejetos em córrego em região onde não fora criada, por omissão do Poder Público, rede de coleta de esgoto. Pediu-se a condenação do Município a urbanizar o local com implantação de coletores e interceptores sanitários no curso d'água, e da Copasa a dotar a rua de sistema de esgotamento sanitário, tudo sob pena de multa. A sentença de procedência foi anulada pelo Tribunal de origem, sob o fundamento de que ao Poder Judiciário não é dado determinar e definir a realização, pelo Executivo, de obras públicas de grande envergadura. 2. A Administração
\end{abstract}

\footnotetext{
116 KRELL, Andreas Joachim. Realização dos direitos fundamentais sociais mediante controle judicial da prestação dos serviços públicos básicos: (uma visão comparativa). Revista de Informação Legislativa, Brasília vol. 36, nº 144, 1999. p. 250.

${ }_{117}$ STJ, Recurso Especial n 1.220.669 - MG (2010/0193970-0), Rel. Min. Herman Benjamin, Brasília (DF), 17 de abril de 2012. Disponível em: https://ww2.stj.jus.br/processo/revista/inteiroteor/?num_registro=201001939700\&dt_publicacao=1 8/12/2015. Acesso em: 25 de maio de 2018.
} 
Pública submete-se, nem precisaria dizer, ao império da lei, inclusive quanto à conveniência e oportunidade do ato administrativo. Se comprovado tecnicamente ser imprescindível, para a proteção da saúde da população e do ambiente, a realização de obras e atividades, atribui-se ao Ministério Público e a outros colegitimados da Ação Civil Pública o direito de exigi-las judicialmente. 3. No que se refere ao saneamento ambiental, o que se tem hoje no Brasil, ao contrário da situação prevalente até poucos anos atrás, não mais é a frouxa opção abstrata de agir deixada à Administração Pública, mas verdadeiro dever-poder de caráter ope legis, e não ope judicis. Daí que o autor de Ação Civil Pública, em tal contexto, não postula que o juiz invente obrigações estatais, escreva ou reescreva, a seu modo, lei que nunca existiu, mas deveria ter existido, ou lei que existe, mas descuidou-se de dispor da matéria como seria, na sua opinião pessoal, de rigor. Diversamente, pretende-se, e não parece muito, que o Judiciário se recuse a assistir - como se fora instituição fantoche do discurso e da prática jurídicos - deveres legais serem aberta e impunemente descumpridos pelo administrador-destinatário da norma federal, estadual ou municipal. (...). 5. Desaconselhável impedir, ab initio, o Poder Judiciário de atuar no dever-poder de fiscalização do cumprimento da lei pelo Estado, desautorizando, assim, o trâmite de demandas propostas que visem à proteção da saúde pública e do ambiente por motivo de atos supostamente omissivos. Precipitada, portanto, a extinção do processo sem julgamento de mérito, com amparo no art. 267, VI, do CPC, quando presentes as condições da ação: legitimidade das partes, interesse processual e pedido juridicamente possível. 6 . Recurso Especial provido para anular o acórdão recorrido, determinando-se ao Tribunal de origem que proceda ao julgamento do mérito da demanda." (STJ, Recurso Especial n ${ }^{\circ}$ 1.220.669 - MG (2010/0193970-0), Rel. Min. Herman Benjamin, Brasília (DF), 17 de abril de 2012)

No caso concreto, o Recurso Especial reformou decisão do Tribunal de Justiça de Minas Gerais que havia estabelecido não ser possível ao Judiciário impor, ao Executivo, a realização de obras públicas tão impactantes e amplas. Fixou-se, pela Corte Federal, que mesmo no exercício do poder discricionário, o Poder Público submete-se à lei. Ou seja, que o autor da ação civil pública tão somente aduziu em juízo a observância, pelo Estado, de seu poder-dever, constitucional e legal, em garantir o saneamento ambiental.

Em relação ao poder discricionário, José dos Santos Carvalho Filho o define como "prerrogativa concedida aos agentes administrativos de elegerem, entre várias condutas possíveis, a que traduz maior conveniência e oportunidade para o interesse público."118 Desse modo, os juízos de conveniência e oportunidade atribuídos ao administrador não podem se

${ }^{118}$ CARVALHO FILHO, José dos Santos. Manual de direito administrativo. $27^{\mathrm{a}}$ edição. São Paulo: Atlas, 2014. p. 51-52. 
dissociar do "o atendimento aos interesses da coletividade." Ou seja, ao escolher como e quando praticar determinado ato, o administrador não pode escusar-se de atentar para sua compatibilidade ante ao ordenamento jurídico e suas finalidades, sob pena de constituir-se tal poder um locus de arbítrios, abusos de poder, e violações às normas jurídicas, aos direitos fundamentais.

Assim, caso constate-se não haver, de fato, adequada disponibilização do serviço público de saneamento básico, imediatamente surge o interesse público e social na sua efetivação, o qual é insuscetível de disposição pelos agentes públicos. Caberá, então, aos legitimados da ação civil pública provocar o Judiciário para que o mesmo, tutelando os direitos difusos envolvidos, corrija as condutas praticadas pelo Estado que não se coadunam com a ordem jurídica.

Ademais, salienta-se que a legítima pretensão autoral na ação civil pública reside na busca pelo cumprimento das disposições e finalidades constitucionais e legais que estejam sendo inobservadas pelo Poder Público. Consequentemente, o acórdão reconhece expressamente, nesses casos, a possibilidade jurídica do pedido, a legitimidade das partes e o interesse processual.

Ainda no âmbito do Superior Tribunal da Justiça, no Recurso Especial $\mathrm{n}^{\circ} 1366331^{119}$, reconheceu-se a violação ao artigo 45 da Lei 11445/2007, quando o TJRS não determinou que fossem adotadas todas as providencias necessárias para a total implantação da pretensão veiculada na ação civil pública sobre o serviço público de saneamento básico. Assim, deu-se provimento ao Recurso Especial para reformar a decisão do Tribunal gaúcho, e determinar o cumprimento das obrigações pendentes pelo Poder Público, nos seguintes termos:

"ADMINISTRATIVO. PROCESSO CIVIL. AÇÃO CIVIL PÚBLICA. REDE DE ESGOTO. VIOLAÇÃO AO ART. 45 DA LEI N. 11.445/2007. OCORRÊNCIA.

${ }^{119}$ STJ, Recurso Especial n ${ }^{\circ} 1.366 .331$ - RS (2012/0125512-2), Rel. Min. Humberto Martins, Brasília (DF), 16 de dezembro de 2014. Disponível em: https://ww2.stj.jus.br/processo/revista/inteiroteor/?num_registro=201201255122\&dt_publicacao $=1$ 9/12/2014. Acesso em: 25 de maio de 2018. 
DISCRICIONARIEDADE DA ADMINISTRAÇÃO. RESERVA DO POSSÍVEL. MÍNIMO EXISTENCIAL. (...) 5. O acórdão recorrido deu interpretação equivocada ao art. 45 da Lei n. 11.445/2007. No caso descrito, não pode haver discricionariedade do Poder Público na implementação das obras de saneamento básico. A não observância de tal política pública fere os princípios da dignidade da pessoa humana, da saúde e do meio ambiente equilibrado. 6. Mera alegação de ausência de previsão orçamentária não afasta a obrigação de garantir o mínimo existencial. O município não provou a inexequibilidade dos pedidos da ação civil pública. 7. Utilizando-se da técnica hermenêutica da ponderação de valores, notase que, no caso em comento, a tutela do mínimo existencial prevalece sobre a reserva do possível. Só não prevaleceria, ressalta-se, no caso de o ente público provar a absoluta inexequibilidade do direito social pleiteado por insuficiência de caixa - o que não se verifica nos autos. Recurso especial provido." (STJ, Recurso Especial $\mathrm{n}^{\circ} 1.366 .331$ - RS (2012/0125512-2), Rel. Min. Humberto Martins, Brasília (DF), 16 de dezembro de 2014)

Nota-se que o acórdão do STJ expressamente refere-se à ponderação como técnica hermenêutica que permite compatibilizar os valores envolvidos quando, por vezes, há colisão entre a aplicação de uma norma em relação às demais. Esta solução permite harmonizar, através da análise das circunstâncias fáticas e jurídicas de cada caso, a garantia de eficácia dos direitos fundamentais com os princípios orçamentários. Nesse sentido, a supracitada decisão enfatiza a necessidade de absoluta escassez de recursos para mitigar, temporária e parcialmente eficácia de direito sociais, a obrigatoriedade de cumprimento das pretensões requisitadas ao ente federativo.

No REsp $n^{\circ} 1150392^{120}$, por sua vez, o Min. Sérgio Kukina asseverou no a legitimidade do Ministério Público, com fundamento no artigo 129, II e III da CRFB/88, para promover a ação civil pública para fins de compelir o ente federativo a promover o sistema de tratamento de esgoto sanitário, serviço de extrema relevância pública. No caso concreto, reformou-se decisão do TJSC que havia extinguido o processo sem julgamento de mérito por entender que haveria impossibilidade jurídica do pedido.

${ }^{120}$ STJ, Recurso Especial n 1.150 .392 - SC (2009/0142023-8), Rel. Min. Sérgio Kukina, Brasília (DF), 13 de setembro de 2016. Disponível em: https://ww2.stj.jus.br/processo/revista/inteiroteor/?num_registro=200901420238\&dt_publicacao=2 0/09/2016. Acesso em: 27 de maio de 2018. 
Já em relação aos Tribunais de Justiça dos Estados, ressalta-se a decisão do TJRJ na Apelação Cível $\mathrm{n}^{\circ}$ 0384805-82.2012 ${ }^{121}$, na qual reconhece-se a natureza difusa e social do direito ao saneamento básico, atrelado ao meio ambiente, à saúde pública e à moradia. No caso em questão o legitimado ativo da ação civil pública foi a Defensoria Pública, eis que havia a presença de vulneráveis. No polo passivo, por sua vez, incluiu-se o Município do Rio de Janeiro e sua autarquia municipal. Sobre esse ponto específico, a decisão não se atentou à existência de solidariedade do Estado do Rio de Janeiro para figurar na demanda em litisconsórcio passivo, visto que o problema se cinge em área abrangida por Região Metropolitana, fato que atrai, em cooperação como o Município, a responsabilidade e competência do Estado na consecução dos serviços públicos de saneamento básico $^{122}$.

A complexidade da questão reside na necessidade de realização de perícias, licenciamento ambiental, obras de infraestrutura e ações integradas que demandam do Poder Público significativos recursos operacionais e financeiros. No entanto, mesmo reconhecendo-se a escassez e limitabilidade dos recursos públicos, afirmou-se no acórdão não ser este um fato, por si só, apto a obstaculizar o cumprimento das obrigações legais e constitucionais impostas pelo Judiciário.

Assim sendo, a eventual escusa, aventada sobre o argumento da reserva do possível, deverá restar claramente comprovada pelo ente federativo. Nesse sentido, cabe destacar a Ementa do acórdão:

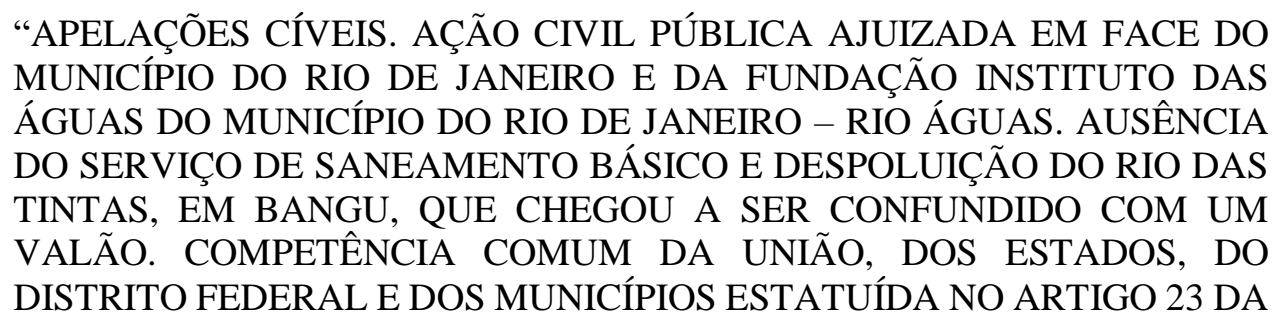

${ }^{121}$ TJRJ, Apelação Cível n 0384805-82.2012.8.19.0001, Décima Primeira Câmara Cível, Rel. Des. Claudio de Mello Tavares, Rio de Janeiro (RJ), 10 de junho de 2015. Disponível em: http://www4.tjrj.jus.br/ejud/ConsultaProcesso.aspx? $\mathrm{N}=2015.001 .15022$. Acesso em: 25 de maio de 2018.

${ }^{122}$ Sobre o tema, ver tópico 1.5. do Capítulo 1. 
CONSTITUIÇÃO FEDERAL. A FALTA DO SANEAMENTO BÁSICO EXPÕE A POPULAÇÃO AO CONTATO COM ANIMAIS PERNICIOSOS E, CONSEQUENTEMENTE, AO RISCO DE CONTRAIR DOENÇAS, AFRONTANDO-SE O DIREITO FUNDAMENTAL À SAÚDE E AO MEIO AMBIENTE EQUILIBRADO, CUJA TUTELA É IMPOSTA A TODOS OS ENTES DA FEDERAÇÃO. A ALEGAÇÃO DO MUNICÍPIO DE QUE A POPULAÇÃO OCUPA IRREGULARMENTE O ENTORNO DO RIO, POR SE TRATAR DE ÁREA NON AEDIFICANDI, APENAS REFORÇA A NEGLIGÊNCIA NA PRESTAÇÃO DO SERVIÇO PÚBLICO, TENDO EM VISTA A AUSÊNCIA DA NECESSÁRIA FISCALIZAÇÃO DECORRENTE DA ATRIBUIÇÃO CONSTITUCIONAL DE PROMOÇÃ̃O DO ADEQUADO ORDENAMENTO URBANO. A INVOCAÇÃO DA RESERVA DO POSSÍVEL, DESACOMPANHADA DA EFETIVA COMPROVAÇÃO DE INSUFICIÊNCIA DE RECURSOS, NÃO SE SOBREPÕE À GARANTIA DO MÍNIMO EXISTENCIAL. CORRESPONDENTE AOS DIREITOS FUNDAMENTAIS BASILARES À SAÚDE, AO MEIO AMBIENTE EQUILIBRADO E À MORADIA DIGNA. DANO MORAL COLETIVO INEXISTENTE, PORQUANTO OS RÉUS NÃO FIGURAM COMO ÚNICOS RESPONSÁVEIS PELA DEGRADAÇÃO AMBIENTAL INVOCADA. RECURSOS PARCIALMENTE PROVIDOS.” (TJRJ, Apelação Cível n ${ }^{\circ}$ 038480582.2012.8.19.0001, Décima Primeira Câmara Cível, Rel. Des. Claudio de Mello Tavares, Rio de Janeiro (RJ), 10 de junho de 2015)

Em síntese, o acórdão reconhece a falha na prestação do serviço público pelo Município e do exercício de seu poder-dever de polícia, bem como a possibilidade de uma ação civil pública veicular a pretensão de obrigação de fazer, dirigida ao Estado, para promover políticas públicas associadas à concretização de direitos sociais e da garantia de preservação da dignidade das pessoas através da vedação à proteção insuficiente do Estado a direitos fundamentais.

Neste ponto, é preciso destacar algumas decisões que expressam a necessidade de as decisões judiciais observarem os princípios da razoabilidade e proporcionalidade. Assim, cabe destacar a Apelação Cível n ${ }^{\circ}$ $0014560362012^{123}$ do TJRJ, que determina a ampliação dos prazos dos prazos estipulados para cumprimento das obrigações previstas na sentença do juízo de primeira instância, assim como exclui determinada imposição que se figurava invasiva à competência da Administração Pública. Desse modo, destaca-se o seguinte trecho da decisão:

${ }^{123}$ TJRJ, Apelação Cível n ${ }^{\circ}$ 0014560-36.2012.8.19.0061, 15 a Câmara Cível, Rel. Des. Maria Regina Nova, Rio de Janeiro (RJ), 04 de agosto de 2015. Disponível em: http://www4.tjri.jus.br/ejud/ConsultaProcesso.aspx?N=2015.001.30973. Acesso em: 25 de maio de 2018. 
“AÇÃO CIVIL PÚBLICA. DIREITO AMBIENTAL. MUNICÍPIO DE TERESÓPOLIS. SENTENÇA DE PROCEDÊNCIA DO PEDIDO DE REVITALIZAÇÃO DO LAGO "IACI", TOMBADO PELO DECRETO N 3003/2003, COM IMLANTAÇÃO DE PROJETO DE SANEAMENTO BÁSICO PARA A REGIÃO DO ENTORNO E ACIMA DA ÁREA DO CORPO HÍDRICO. REDEFINIÇÃO DO ESPELHO D’ÁGUA EM RAZÃO DA IMPLANTAÇÃO DO PROJETO DE REVITALIZAÇÃO. (...) Reforma da sentença apenas para excluir a condenação do Réu a proceder à alteração do Decreto ${ }^{\circ}$ 3003/2003 visando à diminuição do espelho d'água do Lago, considerando que neste caso o Judiciário estará extrapolando de sua função jurisdicional, bem como para ampliar os prazos concedidos para o cumprimento da liminar e das demais providências determinadas pela sentença, as quais foram mantidas por esta instância revisora. (...)” (TJRJ, Apelação Cível n 0014560-36.2012.8.19.0061, 15 Câmara Cível, Rel. Des. Maria Regina Nova, Rio de Janeiro (RJ), 04 de agosto de 2015)

Nesse mesmo sentido, converge a decisão do Agravo de Instrumento $\mathrm{n}^{\circ} 10567100061694001^{124}$ em ação civil pública proferido pelo TJMG, na qual assentou-se:

“AGRAVO DE INSTRUMENTO - AÇÃO CIVIL PÚBLICA - ALEGAÇÃO DE
DEGRADAÇÃO AMBIENTAL - LANÇAMENTO DE EFLUENTES
INDUSTRIAIS E DOMÉSTICOS EM CORPOS HÍDRICOS DO MUNICÍPIO
DE SABARÁ - PRETENSÃO LIMINAR MINISTERIAL DE RESERVA DE
DOTAÇÃO ORÇAMENTÁRIA PARA IMEDIATA IMPLANTAÇÃO DE
SISTEMA DE TRATAMENTO DE ESGOTO EM TODO O MUNICÍPIO -
SUBSTITUIÇÃO DAS CAIXAS COLETORAS EXISTENTES POR FOSSAS
SÉPTICAS - OBRAS DE EXPRESSIVO VULTO - AUSÊNCIA DE
DELIMITAÇÃO DOS RECURSOS DEMANDADOS E DAS OBRAS A SEREM
REALIZADAS - NECESSIDADE DE PRÉVIO ESTUDO E PLANEJAMENTO
TÉCNICO - OPORTUNIDADE DO AGUARDAR A INSTRUÇÃO
PROBATÓRIA PARA MELHOR ESCLARECIMENTO DA QUESTÃO -
RECURSO PROVIDO. 1 - Admite-se o controle judicial do atendimento pelo
Executivo das respectivas incumbências constitucionais, inclusive no que toca à
obrigação do ente público em providenciar a realização de obras para evitar o
prejudicial lançamento de esgoto não tratado diretamente no meio ambiente. 2 - É
notório que a proteção dos corpos hídricos demanda tutela prioritária; todavia, não
se pode ignorar a vultuosidade das obras de infraestrutura necessárias à adequação
do lançamento de resíduos em rios aos níveis toleráveis pelo meio ambiente, a
demandar estudos técnicos prévios que indiquem quais medidas poderão ser
eficientes no controle da degradação ambiental, assim como de que forma e em
quanto tempo poderão ser razoavelmente realizadas. 3 - Envolvendo o feito obras
de engenharia e evidenciada a amplitude do pedido liminar ministerial,
consubstanciado na ordem ao ente público de reserva de dotação orçamentária para
solução de todo o problema ambiental do lançamento de resíduos sólidos nos rios
locais, mostra-se razoável aguardar a instrução do feito para a demonstração de
exequibilidade do empreendimento pela municipalidade." (TJMG, Agravo de

${ }^{124}$ TJMG, Agravo de Instrumento n ${ }^{\circ}$ 1.0567.10.006169-4/001, $6^{\circ}$ Câmara Cível, Rel. Des. Sandra Fonseca, Belo Horizonte (MG), 19 de fevereiro de 2013. Disponível em:

http://www5.tjmg.jus.br/jurisprudencia/formEspelhoAcordao.do. Acesso em: 25 de maio de 2018. 
Instrumento $\mathrm{n}^{\circ}$ 1.0567.10.006169-4/001, 6 Câmara Cível, Rel. Des. Sandra Fonseca, Belo Horizonte (MG), 19 de fevereiro de 2013)

O supracitado Agravo de Instrumento tratou de analisar a plausibilidade da liminar concedida pelo juízo de primeira instância em ação civil pública na qual se determinou reserva de dotação orçamentária para que fossem realizadas imediatamente as medidas requeridas pelo autor da ação coletiva. O Tribunal, a seu turno, reconheceu a competência e responsabilidade do Município, mas constatou que o pedido formulado pelo autor e concedido pelo juízo singular era demasiado genérico, amplo ao determinar a vinculação de recursos públicos para a execução das medidas de saneamento básico. Assim, afirmou-se ser irrazoável que se determinasse de modo tão amplo e de forma imediata e integral a solução do problema de saneamento em toda a extensão territorial do Município.

Ademais, os Desembargadores entenderam que caso se ratificasse a decisão, comprometer-se-ia a própria exequibilidade da liminar. Não seria adequado em tutela provisória, determinar mediadas tão impactantes, financeira e estruturalmente, sobre o Município, inclusive não se havendo ainda especificado quais obras são necessárias, nem mesmo um planejamento para tanto. Reconheceu-se, assim, a necessidade de maior dilação probatória e delimitação da extensão das ações necessárias para fazer cessar as irregularidades que foram constatadas. Além disso, como se trata de um problema complexo, o acórdão também reformou a decisão em tutela provisória no sentido de conferir um tempo maior, mais razoável e hábil, para cumprimento da decisão. No caso em questão, notou-se, ainda, que o Município não havia se quedado totalmente inerte e que já havia buscado um plano de esgotamento sanitário junto a autarquias e empresas públicas estatuais.

O ponto central desse julgado é que ele intenta o equilíbrio na intervenção do Judiciário sobre o Poder Público através da ação civil pública, para agregar mais o aspecto técnico, realizar estudos mais profundos, avaliar 
as nuances do caso concreto com mais precisão e compatibilizar, ao máximo, o interesso social com as limitações do ente federativo.

Importante destacar que toda a jurisprudência colacionada até o momento se coaduna com o entendimento segundo o qual, com base no art. $5^{\circ}$ parágrafo $1^{\circ}$ da $\mathrm{CRFB} / 88$, caberá ao Ente Público o dever de comprovar a escassez ou indisponibilidade de recursos e a gestão eficiente dos mesmos. Em suma:

“(...) os responsáveis pela proteção e implementação de direitos fundamentais, inclusive e especialmente no caso de direitos sociais, onde a insuficiência ou inoperância (em virtude da omissão plena ou parcial do legislador e administrador) causa impacto mais direto e expressivo, deverão observar os critérios parciais da adequação (aptidão do meio no que diz com a consecução da finalidade almejada), necessidade (menor sacrifício do direito restringido) e da proporcionalidade em sentido estrito (avaliação da equação custo-benefício - para alguns, da razoabilidade - no que diz com a relação entre os meios e os fins), respeitando sempre o núcleo essencial do(s) direito(s) restringido(s), mas também não poderão, a pretexto de promover algum direito, desguarnecer a proteção de outro(s) - no sentido de ficar aquém de um patamar minimamente eficiente de realização e de garantia do direito" 125

Enfim, as decisões reconhecem a legitimidade e interesse de agir na propositura de ações civis públicas voltadas ao atendimento do direito ao saneamento básico, analisam a possibilidade jurídica do pedido, a inexistência de recursos financeiros deve ser demonstrada pela Administração Pública, não podendo argui-la genérica e abstratamente, para justificar o não cumprimento de direitos fundamentais. Esse foi o entendimento consignado na Apelação Cível/Reexame Necessário $\mathrm{n}^{\circ}$ $10027110084947001^{126}$ do Tribunal de Justiça de Minas Gerais. e atuação vinculada do administrador público em efetivar o direito ao saneamento básico.

\footnotetext{
${ }^{125}$ SARLET, Ingo Wolfgang. A eficácia dos direitos fundamentais: uma teoria geral dos direitos fundamentais na perspectiva constitucional. 12. ed. rev. atual e ampl. Porto Alegre: Livraria do Advogado, 2015. p. 374.

126. TJMG, Apelação Cível/Reexame Necessário n ${ }^{\circ}$ 1.0027.11.008494-7/001, $5^{\text {a }}$ Câmara Cível, Rel. Des. Versiani Penna, Belo Horizonte (MG), 18 de dezembro de 2014. Disponível em: http://www5.tjmg.jus.br/jurisprudencia/formEspelhoAcordao.do. Acesso em: 27 de maio de 2018.
} 
À guisa de enriquecer o debate, é válido apresentar algumas decisões que se contrapõem à possiblidade de sindicância judicial, em qualquer caso, nas hipóteses de controle de políticas públicas. Nesse sentido, destaca-se a Apelação Cível n ${ }^{\circ} 70030325963^{127}$ decorrente de ação civil pública proposta na comarca de Santa Maria, no Rio Grande do Sul. Admitiu-se, na hipótese, o não cabimento da ação civil pública em razão da inexigibilidade imediata das medidas veiculadas na ação coletiva, em razão do poder discricionário da Administração Pública. Nesse sentido, dispôs a ementa:

\begin{abstract}
“APELAÇÃO CÍVEL. DIREITO PÚBLICO NÃO ESPECIFICADO. AÇÃO CIVIL PÚBLICA. SENTENÇA DE PROCEDÊNCIA, DETERMINANDO A CONFECÇÃO DE PROJETO DE CONSTRUÇÃO DE REDE DE ESGOTO CLOACAL E SUA EXECUÇÃO PELA CONCESSIONÁRIA DE SERVIÇO PÚBLICO - CORSAN. NÃO-CABIMENTO. INTELIGÊNCIA DO ART. 45 DA LEI FEDERAL N ${ }^{\circ}$ 11.445/07 E ARTIGOS 104, 106 E 108 DO DECRETO ESTADUAL $\mathrm{N}^{\circ}$ 23.430/74. INEXISTÊNCIA DE LEI QUE OBRIGUE O PODER PÚBLICO, POR SI OU CONCESSIONÁRIA, A CONSTRUIR REDE COLETORA DE ESGOTO SANITÁRIO. CRITÉRIOS DE CONVENIÊNCIA E OPORTUNIDADE DO ATO ADMINISTRATIVO. IMPOSSIBILIDADE DE ANÁLISE PELO PODER JUDICIÁRIO. ENTENDIMENTO JURISPRUDENCIAL. A rede de esgotos é obra pública indispensável. Sua implantação, todavia, importa demorados projetos técnicos dada a complexidade, além de vultosos investimentos. Por isso nenhuma cidade brasileira dispõe da coleta e do tratamento de esgotos cloacais em todos os seus logradouros, o que constitui, não há esconder, grave problema de saúde pública e de degradação ambiental; umas disponibilizam o serviço em maior, outras em menor extensão; outras tantas nada oferecem. À vista dessa constatação, ou seja, quando ou enquanto não disponibilizada rede pública de esgotamento sanitário, se não para prevenir, ao menos reduzir os danos à saúde e ao meio ambiente, a legislação, assim federal como do Estado do Rio Grande do Sul admitem solução individual e obrigatória, consistente na instalação do sistema de fossas sépticas e sumidouros. $\mathrm{Na}$ verdade, não há lei que obrigue o poder público, por si ou por concessionária, a construir rede coletora de esgoto sanitário, ainda que obra indispensável, como disse acima. É que sua realização exige técnica aprimorada e recursos públicos a mais das vezes insuficientes. Por isso fica a depender das disponibilidades orçamentárias e do juízo de conveniência e oportunidade próprios dos atos de administração. À vista disso o ordenamento jurídico, dá a solução para evitar ou minimizar os danos à saúde ou ao meio ambiente - a instalação em cada edificação do sistema de fossa séptica e sumidouro para colher os efluentes. Apelo provido.
\end{abstract}

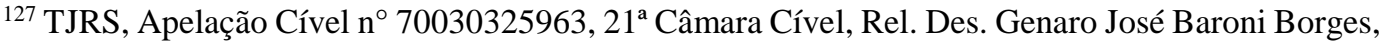
Porto Alegre (RS), 11 de novembro de 2009. Disponível em: http://www.tjrs.jus.br/busca/search?q=70030325963\&proxystylesheet=tjrs_index\&client=tjrs_inde $\underline{x} \&$ filter $=0 \&$ getfields $=* \& a b a=j u r i s \& e n t s p=a \quad$ politica-site $\& w c=200 \& w c \quad m c=1 \& o e=U T F-$ $\underline{8 \& \mathrm{ie}=\mathrm{UTF}-}$

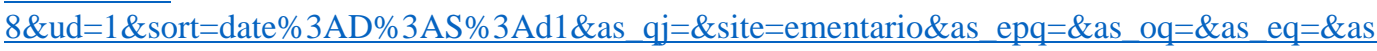
_q=+\#main_res_juris. Acesso em: 27 de maio de 2018. 
Unânime." (TJRS, Apelação Cível n 70030325963, 21 a Câmara Cível, Rel. Des. Genaro José Baroni Borges, Porto Alegre (RS), 11 de novembro de 2009)

O que se constatou, no caso, foi que a imposição obrigatória de rede coletora de esgoto sanitário adentraria o mérito dos atos do administrador público quanto à oportunidade e conveniência, pois inclusive seria possível solucionar o problema de modo mais razoável, através de um meio menos oneroso e complexo para a municipalidade, que seria a implantação de fossas sépticas e sumidouros. Como esse fato foi comprovado através de provas, inclusive pericial, com parecer do órgão ambiental competente (IBAMA), o Tribunal entendeu que a via eleita não se mostrava razoável e proporcional, devendo ser reformada nesse sentido. Vale destacar que o autor da ação civil

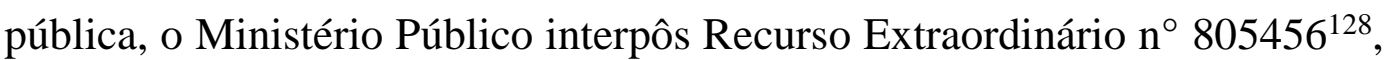
sobre o qual, em decisão monocrática, fora negado seguimento por não atender aos pressupostos de admissibilidade do Recurso Especial. Sobre a decisão que negou conhecimento ao Recurso Extraordinário, vale destacar:

\begin{abstract}
“(...) 2. O Recorrente afirma que o Tribunal de origem teria contrariado os arts. $2^{\circ}$, 200, incisos IV e VIII, e 225 da Constituição da República. 3. Razão jurídica não assiste ao Recorrente. 4. A jurisprudência do Supremo Tribunal Federal é pacífica quanto à possibilidade de o Poder Judiciário examinar a legalidade dos atos da Administração Pública, sem que isso represente ofensa ao princípio da separação dos poderes. Entretanto, o que se tem na espécie vertente é diverso. 5. Com base no laudo de vistoria e perícia técnicas realizadas por profissional capacitado, o Desembargador Relator no Tribunal de Justiça gaúcho convenceu-se de caracterizar mérito administrativo a pretensão do Ministério Público de exigir do Poder Executivo a construção de rede pública de esgoto sanitário por sua concessionária de serviços de saneamento básico. Nesse sentido, a análise da conveniência e oportunidade de execução da obra controvertida é de competência exclusiva da Administração Pública. 6. Assim, a apreciação do pleito recursal demandaria a análise prévia da legislação infraconstitucional aplicável à espécie (Lei federal n. 11.445/2007 e Decreto estadual n. 23.430/1974.) e do conjunto fático probatório dos autos. A alegada contrariedade à Constituição da República, se tivesse ocorrido, seria indireta, o que não viabiliza o processamento do recurso extraordinário.” (STF, Recurso Especial nº 805456/RS, Rel. Min. Cármen Lúcia, Brasília (DF), 2 de maio de 2014)
\end{abstract}

\footnotetext{
${ }^{128}$ STF, Recurso Especial no 805456/RS, Rel. Min. Cármen Lúcia, Brasília (DF), 2 de maio de 2014. Disponível em: http://stf.jus.br/portal/processo/verProcessoAndamento.asp?incidente=4553576. Acesso em: 27 de maio de 2018.
} 
Em sentido semelhante decidiu o Tribunal de Justiça mineiro em Reexame Necessário em Apelação Cível n $10024111808432001^{129}$ :

\begin{abstract}
"REEXAME NECESSÁRIO \ APELAÇÃO CÍVEL - AÇÃO CIVIL PÚBLICA DIREITO CONSTITUCIONAL E ADMINISTRATIVO - OMISSÃO DO PODER PÚBLICO. PRELIMINARES - ILEGITIMIDADE ATIVA AD CAUSAM - AUSÊNCIA DE INTERESSE DE AGIR - INADEQUAÇÃO DA VIA ELEITA - ILEGITIMIDADE PASSIVA DO MUNICÍPIO DE BELO HORIZONTE - REJEIÇÃO. MÉRITO - DIREITO SOCIAL AO SANEAMENTO BÁSICO - INSTALAÇÃO DE "BOCAS-DE-LOBO" E BUEIROS EM VIAS PÚBLICAS - OMISSÃO ABUSIVA POR PARTE DO PODER PÚBLICO MUNICIPAL, A CARACTERIZAR INJUSTIFICÁVEL INÉRCIA ESTATAL INOCORRÊNCIA - DANO AMBIENTAL - AUSÊNCIA DE COMPROVAÇÃO - ATUAÇÃO DO PODER JUDICIÁRIO - IMPOSSIBILIDADE, EM OBSERVÂNCIA A PRINCÍPIOS CONSTITUCIONAIS E LEGAIS POSSIBILIDADE DE VIOLAÇÃO AO PRINCÍPIO DA SEPARAÇÃO DOS PODERES - SENTENÇA REFORMADA, EM REEXAME NECESSÁRIO. 1. Em regra, é defeso ao Poder Judiciário adentrar no mérito dos atos administrativos de efetivação de políticas públicas, cabendo-lhe unicamente examiná-los sob o aspecto de legalidade e moralidade. Tal entendimento tem como fundamento básico o princípio da separação dos Poderes. 2. Todavia, não constitui ingerência indevida a atuação do Judiciário quando impõe ao Executivo o cumprimento de obrigação constitucional e legal, relativamente à qual se posta manifestamente omisso o administrador, notadamente quando a inação estatal implica violação a direito fundamental do indivíduo. 3. Para tanto, a omissão deve decorrer de absoluta inércia da Administração Pública na consecução de seu objetivo de cumprir suas obrigações legais e constitucionais. 4. Não verificação de omissão, na espécie, em que há constatação da existência de sistema de drenagem pluvial nas vias públicas em questão e projeto de realização de obra que solucionaria o problema narrado na presente ação civil pública, respeitada a prioridade definida por órgãos técnicos e profissionais especializados na área. 5. Pretensão inicial que adentra no mérito dos atos administrativos, em especial no tocante à destinação de recursos orçamentários, não sendo possível ao Poder Judiciário impor ao Executivo a maneira como deva agir diante da mora em promover melhorias em rede de drenagem pluvial já existente, quando sequer há comprovação da ocorrência de qualquer dano ambiental. 6. Sentença reformada, em reexame necessário. Prejudicado o recurso voluntário." (TJMG, Apelação Cível/Reexame Necessário $\mathrm{n}^{\circ}$ 1.0024.11.180843-2/001, 5 $5^{\mathrm{a}}$ Câmara Cível, Rel. Des. Áurea Brasil, Belo Horizonte (MG), 26 de setembro de 2013)
\end{abstract}

Neste julgado, reconhece-se a ação civil pública como mecanismo processual eficaz para tutelar direitos difusos, no caso o saneamento básico. Enfatiza-se a primazia pela tutela específica, que o objetivo da ação coletiva é solucionar o problema com o tratamento mais adequado, preferencialmente

\footnotetext{
${ }^{129}$ TJMG, Apelação Cível/Reexame Necessário n ${ }^{\circ}$ 1.0024.11.180843-2/001, $5^{\text {a }}$ Câmara Cível, Rel. Des. Áurea Brasil, Belo Horizonte (MG), 26 de setembro de 2013. Disponível em: http://www5.tjmg.jus.br/jurisprudencia/formEspelhoAcordao.do. Acesso em: 27 de maio de 2018.
} 
através de obrigações de fazer e não fazer. Além disso, afirma-se que, não obstante a Administração Pública dispor, como regra, sobre políticas públicas, quando constatadas violações e omissões na prestação do serviço essencial de saneamento básico, é legítima atuação do Judiciário para preservar a ordem jurídico-social.

Ao longo do acórdão, no entanto, contatou-se que já havia um sistema de rede de esgoto sanitário, embora não completo, e que não houve abuso de poder apto a configurar uma inação inconstitucional do Estado. Assim, decidiu-se pela autocontenção judicial, não se ingerindo nesse caso, para não afrontar a separação dos poderes. Ou seja, haveria certa restrição à ingerência judicial em relação aos atos administrativos que estejam adequados aos critérios da legalidade e aos preceitos da ordem jurídica, pois aí reside a legítima discricionariedade administrativa. ${ }^{130}$

É notório, portanto, que a atuação do Judiciário ocorre à luz dos elementos fáticos e jurídicos presentes no caso concreto. Especificamente no âmbito dos direitos sociais prestacionais, em havendo flagrante omissão, total ou parcial, do Poder Executivo ou Legislativo quanto ao poder-dever de cumprir a diretriz constitucional de conferir efetividade a esses direitos caberá, ao Estado-Juiz, devidamente provocado, intervir com fins de sanar a atuação ilegal do Poder Público, com base em critérios objetivamente estabelecidos. ${ }^{131}$ A necessidade de estabelecimento de parâmetros para atuação judicial, nesses casos, aumenta sensivelmente quando há a presença de conceitos jurídicos indeterminados, pois aí a margem de discricionariedade do administrador é maior. Não obstante essa liberdade de atuação, Ingo Wolfgang Sarlet ${ }^{132}$ aponta para a o poder-dever atribuído ao Poder Público em atentar para as diretrizes e objetivos constitucionais,

\footnotetext{
${ }^{130}$ CARVALHO FILHO, José dos Santos. Manual de direito administrativo. $27^{a}$ edição. São Paulo: Atlas, 2014. p. 54.

${ }^{131}$ BICCA, Carolina Scherer. Judicialização da Política e Ativismo Judicial. Revista de Direito Brasileira, vol. 2, $\mathrm{n}^{\circ}$ 2, 2012. p. 132-133.

${ }^{132}$ SARLET, Ingo Wolfgang. A eficácia dos direitos fundamentais: uma teoria geral dos direitos fundamentais na perspectiva constitucional. $12^{\mathrm{a}}$ ed. rev. atual, e ampl. Porto Alegre: Livraria do Advogado, 2015. p. 387.
} 
principalmente ao exercer o poder discricionário ou deparar-se com conceitos jurídicos indeterminados.

Importante, ainda, destacar a diferença entre conceitos jurídicos indeterminados e poder discricionário. Enquanto aqueles constituem-se expressões vagas, de textura aberta a interpretações, este não significa indeterminação, mas a possibilidade de escolher determinada conduta, dentre outras igualmente válidas. Ou seja, a discricionariedade consiste num poder delegado ao administrador pelo legislador, conferindo a este a competência sobre o modo e tempo para aplicar, dar eficácia à norma, mas não é um método totalmente desvinculado, pois há subordinação do ato administrativo aos preceitos do ordenamento jurídico e suas finalidades. Já em relação à interpretação de conceitos jurídicos indeterminados, esta ocorre num momento anterior à aplicação da norma, pois seus efeitos estão legalmente predefinidos. $^{133}$

\subsubsection{Exequibilidade das Decisões Judiciais}

Diante do exposto até o momento, é possível aferir que é juridicamente admissível e possível uma ação civil pública veicular a responsabilização de agentes públicos em decorrência da omissão a efetivação de políticas públicas, e obrigá-los a proceder às respectivas providências através de obrigações de fazer, não fazer ou mesmo indenizar, de maneira a cumprir a ordem constitucional de eficácia jurídica e social dos direitos fundamentais. No caso do saneamento básico, por exemplo, figura-se razoável requerer, através de obrigação de não fazer, que o ente federativo não lance resíduos sem tratamento sanitário nas águas fluviais, bem como proceda a obrigação de fazer no sentido de promover a respectiva obra de infraestrutura para adequada prestação dos serviços públicos essenciais relacionados ao saneamento básico. Além disso, ainda será possível a requisição de danos

133 CARVALHO FILHO, José dos Santos. Manual de direito administrativo. $27^{\mathrm{a}}$ edição. São Paulo: Atlas, 2014. p. 55-56. 
morais coletivos, se constatadas consequências diretas de danos à saúde coletiva e ao meio ambiente em razão da insalubridade ambiental.

Esses são alguns exemplos de pedidos que podem ser aduzidos em juízo. ${ }^{134}$ Fato este que não significa, na análise das circunstancias fáticas de cada caso, que o Poder Judiciário irá sempre conceder o pleito autoral. Isso porque também cabe ao juiz avaliar a razoabilidade do pedido e a exequibilidade da decisão. Assim, é lícito ao juiz, em observância aos princípios da razoabilidade e proporcionalidade, ampliar os prazos para cumprimento das obrigações, e até mesmo só incluir as despesas relativas às prestações materiais nos orçamentos subsequentes, preservando o equilíbrio orçamentário em determinados casos de comprovada escassez de recursos financeiros.

Além disso, também poderá valer-se do auxílio de peritos e experts no assunto, bem como do conhecimento e estrutura de outras instituições do Estado $^{135}$, o próprio ente federativo ou, por exemplo, autarquias como órgãos ambientais, agências reguladoras, para que estes forneçam ao juízo o máximo possível de subsídios para Todas essas medidas são exemplos que refletem a necessidade de atenção à exequibilidade da decisão judicial na ação civil pública que versar sobre o direito ao saneamento básico, pois a possibilidade de o Poder Judiciário intervir na área de políticas públicas na defesa de direitos sociais não se confunde com a efetividade da sua decisão, algo que por vezes extrapola os limites da ciência jurídica.

Nesse sentido, José dos Santo Carvalho Filho ${ }^{136}$ salienta que na busca por uma maior efetividade dos direitos sociais, compreendidos como direito

\footnotetext{
${ }^{134}$ Conforme dispõe o Artigo 497 do Código de Processo Civil: Na ação que tenha por objeto a prestação de fazer ou de não fazer, o juiz, se procedente o pedido, concederá a tutela específica ou determinará providências que assegurem a obtenção de tutela pelo resultado prático equivalente. Parágrafo único. Para a concessão da tutela específica destinada a inibir a prática, a reiteração ou a continuação de um ilícito, ou a sua remoção, é irrelevante a demonstração da ocorrência de dano ou da existência de culpa ou dolo.

135 Como uma forma de diálogo institucional e flexibilização do procedimento. Sobre o tema ver: SARMENTO, Daniel. O mínimo existencial / The right to basic conditions of life. Revista de Direito da Cidade, [S.1.], v. 8, n. 4, p. 1644- 1689, nov. 2016. p. 1678-1679.

136 CARVAlHO FILHO, José dos Santos. Ação Civil Pública, Comentários por Artigo (Lei $n^{o}$ 7.347, de 24/7/85). $6^{\text {a }}$ edição. Rio de Janeiro: Editora Lumen Juris, 2007. p. 88, 90-91.
} 
subjetivo público a prestações estatais, têm-se diminuído a margem de discricionariedade da administração pública. Afirma em relação a esse fenômeno que é preciso critérios, pois não se pode pretender utilizar a ação civil pública para formular pretensões inexequíveis, com impossibilidade jurídica de cumprimento, manifestamente desarrazoáveis.

Em relação à possibilidade jurídica do pedido veiculado na ação civil pública, reconhece que, embora reconhecida a amplitude do objeto da referida ação e, somado a isso, a possiblidade de cumulação de pedidos para fins da máxima satisfação do direito, a ação civil pública não pode configurar meio para imiscuição, sobre quaisquer circunstâncias, do Judiciário na função administrativa típica de Estado. Desse modo, segundo ele, será juridicamente possível o pedido "quando estiver preordenado a determinada situação concreta, comissiva ou omissiva, causada pelo Estado, da qual se origine a violação dos interesses coletivos ou difusos". ${ }^{137}$ Não o será, contudo, quando se exigir do Estado o cumprimento "de forma genérica, abstrata, inespecífica e indiscriminada, de obrigação de fazer e não fazer." Ou seja, segundo o referido doutrinador, não é possível que se pretenda realizar uma ingerência genérica na atuação da Administração Pública.

Assim, a pretensão veiculada do direito social prestacional deverá considerar as especificidades do caso concreto, ao pretender a efetivação de um direito fundamental. ${ }^{138} \mathrm{Ou}$ seja, como o interesse de agir deve atender aos critérios da necessidade, utilidade e adequação, o pedido deve ser juridicamente possível e a decisão exequível. Desse modo, a condenação na obrigação de fazer na ação civil pública, diante da reserva do possível, por vezes, consistirá na inserção, no orçamento, da verba requisitada para, então, a destinação deste recurso voltada ao cumprimento da obrigação principal. ${ }^{139}$

\footnotetext{
${ }^{137}$ Ibid. p. 85 .

${ }^{138}$ SARLET, Ingo Wolfgang. A eficácia dos direitos fundamentais: uma teoria geral dos direitos fundamentais na perspectiva constitucional. 12. ed. rev. atual e ampl. Porto Alegre: Livraria do Advogado, 2015. p. 292.

${ }^{139}$ GRINOVER, Ada Pellegrini. O controle das políticas públicas pelo poder judiciário. Revista do Curso de Direito da Faculdade de Humanidades e Direito, v. 7, n. 7, 2010. p. 17.
} 
Em relação ao caráter dessas decisões, é preciso mencionar que seu cumprimento envolve atos complexos e de grande amplitude. Suponha-se uma decisão que condene um Município a prover, através de obras, toda a infraestrutura e a posterior execução dos serviços públicos que integram o saneamento básico. Nesse exemplo, o Município deverá realizar cumulativamente, dentre outras medidas, a obtenção de prévio licenciamento ambiental junto ao órgão ambiental competente para o projeto, a instalação e operação dos serviços. Também precisará obter a outorga do direito de uso da água junto ao ente federativo que detiver o domínio do recurso hídrico.

Além disso, provavelmente deverá realizar procedimentos licitatórios para realizar as obras necessárias ao empreendimento e, posteriormente, para delegar a prestação do serviço público ao terceiro setor. Afora esses vetores, ainda terá que compatibilizar e equilibrar os elevados custos financeiros de todas essas obrigações (despesas) em seu respectivo orçamento, que também deverá atender a outras prioridades sociais. O que se pretende com isso é apenas demonstrar algumas das dificuldades práticas que o gestor público deverá suportar quando da execução dessas decisões judiciais.

São decisões que envolvem diversos aspectos técnicos, complexos e com potencial de impacto na própria estrutura do Estado. Desse modo, o Judiciário, ao atuar no controle de políticas públicas, deveria intentar dialogar com as demais instituições do Estado, para proferir a decisão a mais exequível e harmônica com a ordem jurídica possível, tutelando adequadamente a demanda social. Nas palavras de Daniel Sarmento:

\footnotetext{
"Essas técnicas decisórias podem ser empregadas no Brasil tanto no âmbito de ações coletivas como no contexto da jurisdição constitucional concentrada. Elas viabilizam intervenções jurisdicionais mais inteligentes, inclusive para o enfrentamento de lesões sistemáticas ao mínimo existencial, que frequentemente ocorrem em países subdesenvolvidos e que não teriam como ser equacionadas de forma satisfatória pelo Poder Judiciário. Veja-se, no Brasil contemporâneo, as questões atinentes à péssima qualidade do ensino público (...), bem como a deficiência das políticas públicas de universalização do saneamento básico, que "mata" anualmente milhares de pessoas carentes. O mínimo existencial está diretamente implicado nesses casos e, nada obstante, não parece que o Judiciário tenha a menor condição de equacioná-los sozinho.
}

(...) 
O Judiciário pode destravar bloqueios políticos e sociais existentes no equacionamento de certos temas, conferindo visibilidade a questões importantes ligadas ao mínimo existencial e forçando os demais poderes a agir, sem, no entanto, apresentar soluções prontas para problemas altamente complexos, que muitas vezes ele não teria condições de elaborar a contento.

(...)

O Poder Judiciário tem plena legitimidade para atuar nessa seara, garantindo o mínimo existencial mesmo quando isso envolva eventual interferência nas escolhas alocativas e desalocativas adotadas pelo Estado, que não se coadunem com a prioridade constitucional de atendimento às necessidades básicas das pessoas. Mas os déficits de capacidade institucional do Judiciário não permitem que ele assuma qualquer tipo de protagonismo na matéria. Esse déficit, aliado ao princípio democrático, recomenda que, quando for necessário criar ou alterar políticas públicas para garantir o mínimo existencial, a atuação jurisdicional se dê preferencialmente por meio de técnicas flexíveis, baseadas no diálogo interinstitucional. O mínimo existencial deve ser garantido pelo Estado e pela sociedade para todos, mas o foco prioritário tem de recair sobre os segmentos mais vulneráveis da população." ${ }^{140}$

Assim, é possível destacar, como alguns dos principais princípios norteadores da atuação do Judiciário no controle de políticas públicas, a proporcionalidade, a razoabilidade, a garantia do mínimo existencial, a universalidade dos serviços públicos, a justiça social. Diante disso, a reserva do possível pode ser compreendida como um postulado de razoabilidade ao se exigir, individual ou coletivamente, o cumprimento de um direito ou pretensão ao Estado.

Esse princípio, como ficou consignado até aqui, não pode impedir a garantia do mínimo existencial e da dignidade humana. Ou seja, não obstante a reserva do possível não se configurar um obstáculo intransponível à efetivação de direitos, - especialmente quando se tratar de direitos fundamentais, tão básicos e essenciais que impõem urgência e indispensabilidade de efetividade, como é o caso do saneamento, saúde e meio ambiente - em certos casos, como de constatada escassez de verbas, será um parâmetro para orientar o padrão e a razoabilidade das decisões judiciais - que não deverá ser olvidado pelos magistrados - para contribuir a uma maior eficiência e exequibilidade das mesmas, quando de seu cumprimento. E, como segundo aspecto da reserva do possível a se

\footnotetext{
${ }^{140}$ SARMENTO, Daniel. O mínimo existencial / The right to basic conditions of life. Revista de Direito da Cidade, [S.1.], v. 8, n. 4, p. 1644- 1689, nov. 2016. p. 1678-1679.
} 
considerar, a disponibilidade fática de recursos financeiros do Estado para efetivar as pretensões aduzidas, situação que pode significar uma postergação parcial, temporária e excepcional da plena eficácia do direito em razão de circunstancias que extrapolam o campo de controle jurídico.

Em suma, cabe destacar que no caso do saneamento básico se está diante de um direito difuso a prestações estatais, cuja efetivação invariavelmente produz efeitos benéficos a todos, um direito público por excelência. Nas demandas coletivas, essas questões podem ser examinadas pelo Judiciário de um modo mais completo e abrangente ${ }^{141}$, e os legitimados para propositura da ação civil pública como regra devem dispor de condições adequadas para representar os direitos difusos. Esse caráter geral da ação coletiva vai de encontro ao princípio da universalização do acesso ao serviço público de saneamento básico, que é um princípio basilar.

${ }^{141}$ BARCELLOS, Ana Paula de. A eficácia jurídica dos princípios constitucionais: O princípio da dignidade humana. $3^{\text {a }}$ ed. revista e atualizada. Rio de Janeiro: Renovar, 2011. p. 355-356, 359-360. 


\section{Conclusão}

A ação civil pública é um instrumento de proteção de direitos difusos, portanto, é possível promover a tutela coletiva que tenha por objeto o serviço público de saneamento básico, quando se pretende, através da sindicância judicial sobre políticas públicas e prestação de serviços, que a efetivação de direitos sociais prestacionais seja realizada pelo Estado.

O saneamento básico compreende um conjunto de estruturas e serviços públicos, de significativa amplitude e complexidade, cuja implementação é indispensável à garantia da saúde pública e do meio ambiente ecologicamente equilibrado. É inegável a presença do interesse público e social nesse caso, pois a efetivação desse direito não só previne a proliferação de doenças, como possibilita o desenvolvimento humano em seus aspectos físico, mental e social.

O direito ao saneamento básico possui envergadura constitucional, constituindo-se autêntico direito social prestacional fundamental, que demanda do Estado uma atuação positiva para sua plena eficácia. Outrossim, possui esse direito uma robusta previsão na legislação infraconstitucional, através da qual é expressamente elencado, na esfera de lei nacional que cuida da política pública voltada ao saneamento, constituindo sua efetividade um poder-dever da Administração Pública.

O Estado tem que atender um patamar básico de eficácia dos direitos fundamentais, uma baliza que proíbe a tutela insuficiente do direito, mas que não impede que os direitos fundamentais sejam progressivamente efetivados e aprimorados.

Os direitos fundamentais, insculpidos no título II da CRFB/88 abrangem os direitos individuais e coletivos, os direitos de nacionalidade, os políticos e os sociais, além dos demais previstos na legislação, em razão da amplitude conferida pelo art. $5^{\circ}, \S 2^{\circ}$ da CRFB/88. Dentre as principais características dos direitos fundamentais, destacam-se, a universalidade, indistintamente destinam-se a todos, a inalienabilidade, ou seja, são 
indisponíveis e não podem ser transferidos. Além dessas, há a inviolabilidade, pois impõem respeito tanto pelo Estado, eficácia vertical dos direitos fundamentais, como pela sociedade, eficácia horizontal dos direitos fundamentais.

Outra característica marcante é a limitabilidade, ou seja, não são direitos absolutos, desde que razoáveis e proporcionais, podem sofrer restrições. São, ainda, interdependentes, complementares, de modo que a interpretação de uma norma sobre direitos fundamentais não pode desconsiderar a coexistência das demais, a fim de observar a máxima efetividade desses preceitos. Por fim, ressaltam-se a historicidade desses direitos, que são passíveis de mutação em seu significado e alcance ao longo do tempo, bem como o reconhecimento de que um direito pode restringir a aplicação do outro, na medida em que não há hierarquia entre eles. Essa última característica demanda uma técnica interpretativa específica de ponderação dos valores envolvidos, a fim de harmonizá-los, restringindo-os o mínimo possível, a fim de assegurar o núcleo essencial do direito fundamental ao decidir-se qual deles prevalecerá no caso concreto.

Os direitos fundamentais, portanto, consistem em posicionamentos jurídicos positivados direcionados à proteção dos indivíduos e coletividade, cujo conteúdo é de extrema relevância no ordenamento jurídico, parte integrante da própria finalidade do Estado, a ponto de constituírem-se tais direitos autênticas cláusulas pétreas. São, portanto, insuscetíveis de disposição pelos Poderes Constituídos da República. Enquanto espécie do gênero direito fundamentais, os direitos sociais são, concomitantemente, direitos de defesa da liberdade e igualdade, e deveres de prestação, de ação concreta do Estado para sua realização no plano fático. Uma das premissas dos direitos sociais consiste em atribuir, equitativamente, um tratamento legal desigual a indivíduos que faticamente encontram-se em situação de flagrante desigualdade, seja de ordem econômica, como social.

Considerando a dimensão objetiva dos direitos sociais prestacionais, as normas constitucionais que versam sobre direitos fundamentais impõem 
obrigatoriamente ao legislador atuação comissiva no sentido de criar leis regulamentando-as e positivando-as, para sua fruição, o que ocorreu com o direito ao saneamento básico. São preceitos que, ao concederem e garantirem o direito subjetivo a uma pretensão realizada pelo Estado, requerem do legislador e administrador público atuação para efetivá-los. Em sua dimensão subjetiva, significam o direito de receber prestações de caráter social do Estado e sua relação com os limites de esforços e obrigações do Estado para concretizá-los, da justiça social, e de que maneira esses interesses podem ser veiculados e exigidos na via judicial.

Nota-se que o uso da via judicial nesses casos, é absolutamente legítima e harmônica com a ordem jurídica. Contudo, ainda que a incidência da judicialização de questões políticas seja possível, esse fenômeno reflete a omissão e descumprimento de deveres pelos Poderes Executivo e Legislativo, vez que destes espera-se a primazia para elaborar e implementar políticas públicas, obras e serviços de interesse social.

O controle de atos administrativos e a intervenção judicial no campo de políticas públicas não significa, a priori, violação à separação dos poderes. Esse princípio pressupõe, na realidade, a possibilidade de controles recíprocos entre os poderes constituídos. Não se pode olvidar que mesmo no exercício do poder discricionário, a administração pública sujeita-se aos princípios constitucionais, como a legalidade, eficiência e moralidade, conforme determina o artigo 37 da CRFB/88. Isso significa que a gestão dos recursos públicos não é atividade totalmente desvinculada e insuscetível de controle judicial. O erário público deve ser bem administrado e suas verbas direcionadas à consecução dos objetivos da Constituição Federal. Especialmente, no âmbito do saneamento básico, a noção de necessidade de proteção suficiente do direito deve ser um elemento considerado pelo julgador ao exercer o controle de políticas públicas, a fim de conferir-lhe eficácia social.

No que diz respeito à reserva do possível, esta pode ser compreendida tanto como um critério de razoabilidade da pretensão aduzida frente ao 
Estado, como uma condição de realidade que, em razão da escassez de recursos públicos, decorrente de justo e comprovado motivo, poderá mitigar, de forma parcial e temporária, a eficácia social de um direito social prestacional. Na verdade, a insuficiência de recursos materiais não deve ser compreendida como um óbice à concretização de direitos sociais, mas uma circunstância que, ao ser analisada no caso concreto, poderá influir em como aplicar-se-ão os postulados da razoabilidade e proporcionalidade.

É preciso critérios, balizas, tanto para aferir a compatibilidade da decisão judicial com a ordem jurídica, como sua exequibilidade. Assim, através da jurisprudência elencada, a qual reconhece a possibilidade da intervenção judicial, buscou-se demonstrar como a prática forense lida com essas questões sensíveis. No caso de a garantia de eficácia do direito ao saneamento básico colidir com outros valores e direitos consagrados no ordenamento jurídico, a técnica da ponderação deverá ser usada para solucionar o aparente impasse e, concomitantemente, preservar ao máximo os demais preceitos que não prevaleçam no caso concreto.

O Brasil ainda é fortemente marcado pelas desigualdades sociais e violações a direitos elementares do ser humano. Diante desse panorama, a omissão e negligência do Poder Público para cumprir seus deveres no âmbito do direito social ao saneamento básico não são razoáveis ou mesmo consentâneas com os propósitos constitucionais de proteção à dignidade humana, de promoção do bem comum numa sociedade livre, justa e solidária, que visa à erradicação da pobreza e garantia do desenvolvimento da nação. Para tanto, consignou-se que a reserva do possível e a separação dos poderes, são valores que podem e devem ser harmonizados com a garantia dos direitos fundamentais, não constituindo obstáculo intransponível à sua eficácia social.

Assim, a ação civil pública figura como um dos instrumentos previstos no ordenamento jurídico mais adequados para provocação do Poder Judiciário a fim de que o mesmo, atento aos limites de suas atribuições, obrigue o Executivo a proceder conforme os objetivos da Constituição 
Federal e legislação infraconstitucional, a concretizar o acesso universal ao serviço público de saneamento básico, efetivando um direito social fundamental que está intrinsecamente relacionado à saúde pública e à higidez ambiental. 


\section{Bibliografia}

BARCELlOS, Ana Paula de. A eficácia jurídica dos princípios constitucionais: $O$ princípio da dignidade humana. $3^{\mathrm{a}}$ edição revista e atualizada. Rio de Janeiro: Renovar, 2011. 378 p.

BARBOZA, Estefânia Maria de Queiroz; KOZICKI, Katya. Judicialização da política e controle judicial de políticas públicas. Revista Direito GV, vol. 8, $\mathrm{n}^{\mathrm{o}}$ 1, p. 059-085, janeiro de 2012. Disponível em: <http://bibliotecadigital.fgv.br/ojs/index.php/revdireitogv/article/view/2397 0>. Acesso em: 15 de outubro de 2017.

BARROSO, Luis Roberto. Saneamento básico: competências constitucionais da União, Estados e Municípios. Revista Eletrônica de Direito Administrativo Econômico (REDAE), Salvador, Instituto Brasileiro de Direito Público, n 11, agosto/setembro/outubro de 2007. Disponível em: <http://www.direitodoestado.com.br//redae.asp>. Acesso em: 15 de outubro de 2017.

BARROSO, Luis Roberto. Curso de direito constitucional contemporâneo: os conceitos fundamentais e a construção do novo modelo. $4^{\mathrm{a}}$ edição. São Paulo: Saraiva, 2013. 505 p.

BARROSO, Luis Roberto; BARCELLOS, Ana Paula de. O começo da história. A nova interpretação constitucional e o papel dos princípios no direito brasileiro. Revista de Direito Administrativo, Rio de Janeiro, vol. 232, p. 141-176, abril de 2003. Disponível em: <http://bibliotecadigital.fgv.br/ojs/index.php/rda/article/view/45690/45068> . Acesso em: 21 de maio de 2018. 
BICCA, Carolina Scherer. Judicialização da Política e Ativismo Judicial. Revista de Direito Brasileira, vol. 2, n 2, p. 121-139, outubro de 2012. Disponível em: Disponível em: <http://www.indexlaw.org/index.php/rdb/article/view/2700>. Acesso em: 04 de junho de 2018.

CALIXTO, Fernanda Karoline Oliveira. Orçamento público e proteção ambiental. Custos do direito ao meio ambiente ecologicamente equilibrado. Revista Jus Navigandi, ISSN 1518-4862, Teresina, ano 19, n. 4024, 8 jul. 2014. Disponível em: <https://jus.com.br/artigos/28674>. Acesso em: 13 out. 2017.

CARVALHO FILHO, José dos Santos. Ação Civil Pública, Comentários por Artigo (Lei n ${ }^{\circ}$ 7.347, de 24/7/85). $6^{\text {a }}$ edição. Rio de Janeiro: Editora Lumen Juris, 2007. 518 p.

CARVALHO FILHO, José dos Santos. Manual de direito administrativo. $27^{a}$ edição. São Paulo: Atlas, 2014. 1331 p.

DE CARVAlHO, Sonia Aparecida; ADOLFO, Luiz Gonzaga Silva. $O$ direito fundamental ao saneamento básico como garantia do mínimo existencial social e ambiental. Revista Brasileira de Direito, Passo Fundo, vol. 8, $\mathrm{n}^{\mathrm{o}}$ 2, p. 6-37, outubro de 2012. Disponível em: $\langle$ https://seer.imed.edu.br/index.php/revistadedireito/article/view/286>. Acesso em: 15 out. 2017.

DIDIER Jr, Fredie, ZANETI Jr, Hermes. Curso de Direito Processual Civil: Processo Coletivo. $12^{\mathrm{a}}$ edição, volume 4. Salvador, BA: JusPODIVM, 2018. $576 \mathrm{p}$. 
DI PIETRO, Maria Sylvia Zanella. Direito administrativo. 30ª edição. Rio de Janeiro: Forense, 2017. 1088 p.

DONIZETTI, Elpídio; CERQUEIRA, Marcelo Malheiros. Curso de Processo Coletivo: Contém Jurisprudência Temática e Índice Alfabético de Assuntos. $1^{\mathrm{a}}$ edição. São Paulo: Atlas, 2010. 557 p.

GRANDO, Fabiane. O controle judicial das políticas públicas. Revista Internacional Consinter de Direito ano $\mathrm{I}, \mathrm{n}^{\circ} \mathrm{I}, \mathrm{p} .499-516,2^{\circ}$ semestre de 2015. Disponível em:

<https://editorialjurua.com/revistaconsinter/revistas/ano-i-volume-i/>. Acesso em: 15 de outubro de 2017.

GRINOVER, Ada Pellegrini. O controle das políticas públicas pelo poder judiciário. Revista do Curso de Direito da Faculdade de Humanidades e Direito, vol. $7, \quad \mathrm{n}^{\mathrm{o}} \quad 7, \quad 2010 . \quad$ Disponível em: $<$ https://www.metodista.br/revistas/revistasims/index.php/RFD/article/view/1964/1969>. Acesso em: 04 de junho de 2018.

HENNIG LEAL, Mônia Clarissa; SCHNORR ALVES, Fernando Roberto. Razoabilidade e Teoria da Reserva do Possível como Fundamentos para o Controle Jurisdicional de Políticas Públicas: Uma Análise a partir da Teoria do Discurso. Espaço Jurídico Journal of Law, vol. 17, n² 2, p. 587-606, agosto de 2016. Disponível em: <https://editora.unoesc.edu.br/index.php/espacojuridico/article/view/9255>. Acesso em: 16 outubro de 2017.

KRELL, Andreas Joachim. Realização dos direitos fundamentais sociais mediante controle judicial da prestação dos serviços públicos básicos: (uma visão comparativa). Revista de Informação Legislativa, Brasília vol. 36, nº 
144, p. 239-260, outubro/dezembro 1999. Disponível em: <http://www2.senado.leg.br/bdsf/handle/id/545>. Acesso em: 15 de outubro de 2017.

LEITE, Carlos Henrique Costa. A supremacia do interesse público sobre o privado e os conceitos jurídicos fundamentais de Wesley Hohfeld. Revista Jus Navigandi, ISSN 1518-4862, Teresina, ano 16, n. 3069, 26 nov. 2011. Disponível em: <https://jus.com.br/artigos/20509>. Acesso em: 4 jun. 2018.

MACHADO, Paulo Affonso Leme. Direito ambiental brasileiro. $22^{\mathrm{a}}$ edição. São Paulo: Malheiros, 2014. 1424 p.

MANCUSO, Rodolfo de Camargo. Ação civil pública: em defesa do meio ambiente, do patrimônio cultural e dos consumidores (lei 7.347/85e legislação complementar). $10^{\mathrm{a}}$ edição. São Paulo: Revista dos Tribunais, 2007. 445 p.

MARTINS, Ricardo Marcondes. Titularidade do serviço de saneamento básico. Revista de Direito Administrativo, Rio de Janeiro, vol. 249, p. 171198, setembro de 2008. Disponível em: <http://bibliotecadigital.fgv.br/ojs/index.php/rda/article/view/2545/2858>. Acesso em: 28 de outubro de 2017.

MAZZILLI, Hugo Nigro. A defesa dos interesses difusos em juízo: meio ambiente, consumidor, patrimônio cultural, patrimônio público e outros interesses. 30. ed. São Paulo: Saraiva, 2017. 1024 p.

MILARÉ, Édis. Direito do ambiente. $10^{\mathrm{a}}$ edição. São Paulo: Revista dos Tribunais, 2015. $1707 \mathrm{p}$. 
MOREIRA NETO, Diogo de Figueiredo. Curso de Direito Administrativo. $16^{\mathrm{a}}$ edição. Rio de Janeiro: Forense, 2014. 887 p.

NADIM DE LAZARI, Rafael José. Da Possibilidade de Implementação de Normas Sociais Programáticas pelo Poder Judiciário: análise de viabilidade. RFD- Revista da Faculdade de Direito da UERJ-RFD, vol.1, $\mathrm{n}^{\mathrm{o}}$ 20, julho de 2011. Disponível em: <http://www.epublicacoes.uerj.br/index.php/rfduerj/article/view/1484/1643>. Acesso em: 14 de outubro de 2017.

RIBEIRO DA SILVA, Airton; PINTO WEIBLEN, Fabrício. A reserva do possível e o papel do judiciário na efetividade dos direitos sociais. Revista Eletrônica do Curso de Direito da UFSM, Santa Maria, RS, vol. 2, $\mathrm{n}^{\mathbf{o}}$ 2, agosto de 2007. Disponível em: <https://periodicos.ufsm.br/revistadireito/article/view/6793/4109>. Acesso em: 14 de outubro de. 2017.

RODRIGUES, Marcelo Abelha. Processo Civil Ambiental. $4^{\mathrm{a}}$ edição. São Paulo: JusPODIVM, 2016. 320 p.

SILVA, José Afonso da. Curso de Direito Constitucional Positivo. 37 edição. São Paulo: Malheiros, 2014. 934 p.

SARLET, Ingo Wolfgang. A eficácia dos direitos fundamentais: uma teoria geral dos direitos fundamentais na perspectiva constitucional. 12. ed. rev. atual e ampl. Porto Alegre: Livraria do Advogado, 2015. 512 p.

SARLET, Ingo Wolfgang. Os Direitos Fundamentais (Sociais) e a assim chamada Proibição do retrocesso: Contributo para uma Discussão. Revista do Instituto do Direito Brasileiro: RIDB. Faculdade de Direito da 
Universidade de Lisboa. Ano 2, $\mathrm{n}^{\circ}$ 1, 2013. p. 769-820. Disponível em: <http://www.cidp.pt/revistas/ridb/2013>. Acesso em: 14 de outubro de 2017.

SARMENTO, Daniel. O mínimo existencial / The right to basic conditions of life. Revista de Direito da Cidade, [S.1.], vol. 8, no 4, p. 1644-1689, novembro de 2016. Disponível em: <http://www.epublicacoes.uerj.br/index.php/rdc/article/view/26034/19156>. Acesso em: 15 maio 2018.

TORRES, Ricardo Lobo. O mínimo existencial e os direitos fundamentais. Revista de Direito Administrativo, Rio de Janeiro, vol. 177, p. 29-49, jul./set. $1989 . \quad$ Disponível em: 〈http://bibliotecadigital.fgv.br/ojs/index.php/rda/article/view/46113〉. Acesso em: 15 maio de 2018.

Declaração de Estocolmo de 1972 da conferência das Nações Unidas sobre o Meio Ambiente Humano. Disponível em: https://www.apambiente.pt/_zdata/Politicas/DesenvolvimentoSustentavel/1 972_Declaracao_Estocolmo.pdf. Aceso em: 17 de maio de 2018.

Declaração do Rio de Janeiro de 1992 da conferência das Nações Unidas sobre o meio ambiente e desenvolvimento humano. Disponível em: http://www.onu.org.br/rio20/img/2012/01/rio92.pdf. Acesso em: 17 de maio de 2018.

STF, Mandado de Segurança n ${ }^{\circ} 22164$, Rel. Min. Celso de Mello, Tribunal Pleno, Brasília (DF), 30 de outubro de 1995

STF, Recurso Especial nº 805456/RS, Rel. Min. Cármen Lúcia, Brasília (DF), 2 de maio de 2014. 
STJ, Recurso Especial n ${ }^{\circ}$ 1.220.669 - MG (2010/0193970-0), Rel. Min. Herman Benjamin, Brasília (DF), 17 de abril de 2012.

STJ, Recurso Especial n 1.366 .331 - RS (2012/0125512-2), Rel. Min. Humberto Martins, Brasília (DF), 16 de dezembro de 2014.

STJ, Recurso Especial n 1.150.392 - SC (2009/0142023-8), Rel. Min. Sérgio Kukina, Brasília (DF), 13 de setembro de 2016.

TJMG, Agravo de Instrumento $\mathrm{n}^{\circ}$ 1.0567.10.006169-4/001, $6^{\circ}$ Câmara Cível, Rel. Des. Sandra Fonseca, Belo Horizonte (MG), 19 de fevereiro de 2013.

TJMG, Apelação Cível/Reexame Necessário n $1.0024 .11 .180843-2 / 001,5^{\mathrm{a}}$ Câmara Cível, Rel. Des. Áurea Brasil, Belo Horizonte (MG), 26 de setembro de 2013.

TJMG, Apelação Cível/Reexame Necessário n 1.0027.11.008494-7/001, 5 Câmara Cível, Rel. Des. Versiani Penna, Belo Horizonte (MG), 18 de dezembro de 2014

TJRJ, Apelação Cível $\mathrm{n}^{\circ}$ 0384805-82.2012.8.19.0001, Décima Primeira Câmara Cível, Rel. Des. Claudio de Mello Tavares, Rio de Janeiro (RJ), 10 de junho de 2015.

TJRJ, Apelação Cível nº 0014560-36.2012.8.19.0061, 15ª Câmara Cível, Rel. Des. Maria Regina Nova, Rio de Janeiro (RJ), 04 de agosto de 2015.

TJRS, Apelação Cível nº 70030325963, $21^{\text {a }}$ Câmara Cível, Rel. Des. Genaro José Baroni Borges, Porto Alegre (RS), 11 de novembro de 2009. 